WWO GEOLOFALAL SRING

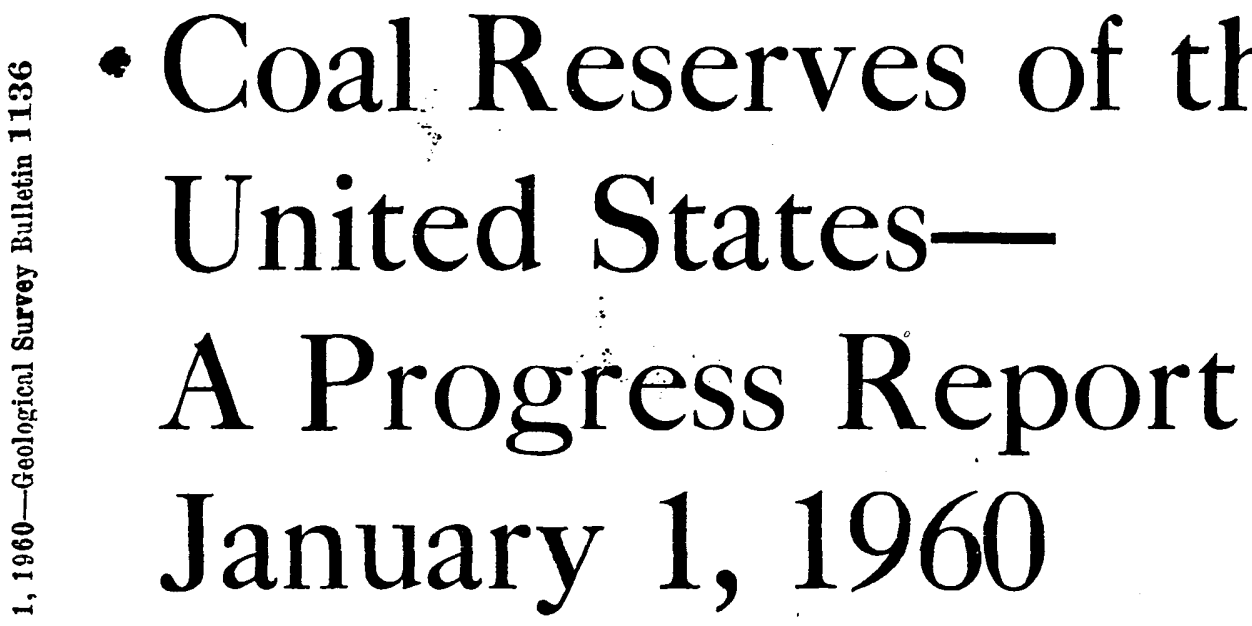

$\begin{array}{lllllllllllllllllllllllllll}\text { G E O L } & \text { O G } & \text { I C A L } & \text { S U R V E Y } & \text { B U L L E T I N } & 1 & 1 & 3 & 6\end{array}$

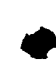




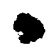

。 
- Coal Reserves of the United States-

A Progress Report January 1, 1960

By PAUL AVERITT

GEOLOGICAL S URVEY B ULLE TIN 1136

A summary of information concerning the quantity and distribution of coal

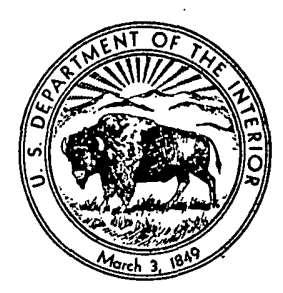


UNITED STATES DEPARTMENT OF THE INTERIOR

STEWART L. UDALL, Secretary

\section{GEOLOGICAL SURVEY}

Thomas B. Nolan, Director

For sale by the Superintendent of Documents, U.S. Government Printing Office Washington 25, D.C. 


\section{CONTENTS}

\begin{tabular}{|c|c|}
\hline & Page \\
\hline Abstract. & \\
\hline Introduction & \\
\hline Acknowledgments & 5 \\
\hline Status of available information & 5 \\
\hline Methods of preparing and reporting coal-reserve estimates... & 12 \\
\hline Reserves versus resources & 12 \\
\hline Classification according to characteristics of the coal & 14 \\
\hline Rank of coal & 14 \\
\hline Grade of coal $\ldots$ & 15 \\
\hline Weight of coal & 17 \\
\hline Thickness of beds & 18 \\
\hline 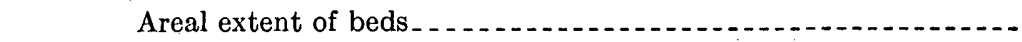 & 20 \\
\hline Thickness of overburden & 20 \\
\hline Classification according to relative abundance of information & 21 \\
\hline Measured reserves. & 21 \\
\hline Indicated reserves & 22 \\
\hline Inferred reserves & 22 \\
\hline Distinction between original, remaining, and recoverable reserves.... & 22 \\
\hline Original reserves & 22 \\
\hline Remaining reserves & 22 \\
\hline Recoverable reserves & 22 \\
\hline Percentage of coal recovered in mining & 23 \\
\hline Underground mining & 24 \\
\hline Strip mining & 25 \\
\hline Distribution of reserves in selected categories & 26 \\
\hline Distribution according to rank & 26 \\
\hline Distribution according to reserve categories other than rank & 29 \\
\hline Distribution according to thickness of overburden & 29 \\
\hline $\begin{array}{l}\text { Distribution according to relative abundance and reliability of } \\
\text { information }\end{array}$ & \\
\hline Distribution according to thickness of coal & 31 \\
\hline Distribution in all categories & 31 \\
\hline Coking-coal reserves & $\begin{array}{l}31 \\
32\end{array}$ \\
\hline Stripping-coal reserves & $\begin{array}{l}32 \\
34\end{array}$ \\
\hline Production of coal in the United States...... & $\begin{array}{l}34 \\
36\end{array}$ \\
\hline Uses of coal & $\begin{array}{l}36 \\
39\end{array}$ \\
\hline Minor elements in coal. & $\begin{array}{l}39 \\
40\end{array}$ \\
\hline Uranium. . . . . . . & $\begin{array}{l}40 \\
41\end{array}$ \\
\hline Germanium & $\begin{array}{l}41 \\
4 y^{\prime}\end{array}$ \\
\hline Barium and strontium & 41 \\
\hline 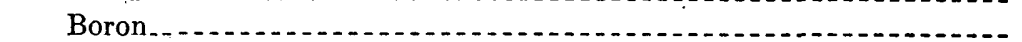 & $\begin{array}{l}42 \\
42\end{array}$ \\
\hline aership of coal lands. & 42 \\
\hline
\end{tabular}


State estimates...

Alabama . .

Bituminous coal._............. 44

Lignite. - .

Alaska_. . . .

Arkansas. ....... 48

Bituminous coal and semianthracite....................... 48

Lignite._.

Colorado _.

Georgia . _ _

Illinois_...

Indiana.

Iowa.... 57

Kansas_._.

Bituminous coal. .

Lignite......

Kentucky _ .

Maryland . . .

Michigan

Missouri-_._.

Montana....

New Mexico

North Carolina_._.

North Dakota...

Ohio

Oklahoma.

Oregon

Pennsylvania

Bituminous coal.

Anthracite...

South Dakota...

Tennessee.

Texas _..... 78

Bituminous coal

Lignite............ 78

Utah

Virginia.

Washington

West Virginia.

Wyoming -........ 83

Other States. . .

Possible additional reserves not included in estimates.... 85

Need for additional work

Other estimates of United States coal reserves....................... 87

M. R. Campbell, 1909 to $1929 \ldots$

United States Coal Commission Committee Report, 1922__.

United States Army Corps of Engineers, 1952_... 88

Peat reserves........ 89

World coal reserves

Relation of coal in the United States to other forms of energy

Problems of comparing estimates of fuels reserves................. 96

Measured or proved reserves...

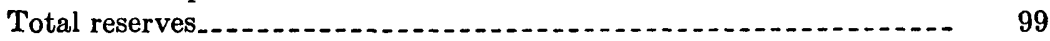




\section{ILLUSTRATIONS}

Figdre 1. Coal fields of conterminous United States

2. Remaining coal reserves of conterminous United States.......-

3. Heat value of coal of different ranks compared to proximate

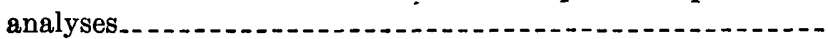

4. Remaining coal reserves of the United States, Jan. 1, 1960, by States according to tonnage and heat value

5. Percentage distribution of estimated original reserves

6. Summary of percentage distribution of estimated original reserves.

7. Distribution, in percent, of cumulative coal production in conterminous United States to Jan. 1, 1960 . .......... 37

8. Coal fields of Alaska

9. Annual production of energy in the United States, 1900-58_.. 94

10. Percentage of total energy supplied by mineral fuels and waterpower, $1900-58$

\section{TABLES}

TABLE 1. Coal reserves of the United States, January 1, 1960, by rank..-

2. Coal reserves of the United States, January 1, 1960, by States

3. Classification of coals by rank

4. Size and percentage distribution of coal-bearing areas in the United States

5. Estimated remaining reserves of the world by regions and by principal coal-producing countries

6. Comparison between remaining recoverable reserves of coal and other fuels in the United States, as of January 1, 1959-60... 


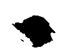

$a$ 


\title{
COAL RESERVES OF THE UNITED STATES- A PROGRESS REPORT, JANUARY 1, 1960
}

\author{
By Paul Afrertit
}

\section{ABSTRACT}

As estimated in this. third progress report, the coal reserves of the United States remaining in the ground on January 1, 1960, total 1,660,290 million toris. This figure is about a 12 percent reduction of the previous Geological Survey estimate. The new total is based on new, detailed, conservative estimates of reserves in Alabama, Arkansas, Colorado, Indiana, eastern Kentucky, Michigan, Montana, New Mexico, North Carolina, North Dakota, Oklahoma, South Dakota, Virginia, and Wyoming, prepared since 1947 by the U.S. Geological Survey; on new provisional, but equally conservative estimates of reserves in Alaska, Georgia, Maryland, Oregon, and Utah, based on previous work of the U.S. Geological Survey and other agencies; on estimates of reserves in Illinois, Kansas, Ohio, Pennsylvania, Tennessee, Texas (lignite), and West Virginia, prepared by the geological surveys of those States; and on older and incompletely documented estimates for the few remaining States.

The older estimates were prepared on a highly generalized basis and were intended to represent total possible reserves in beds of all ranges of thickness and depth, and in both explored and unexplored areas. The recent estimates have been prepared on more conservative assumptions than the older estimates and tend to be considerably smaller. New conservative estimates have now been prepared for 26 coal-bearing States, which include roughly 90 percent of the total estimated reserves of the United States.

The estimated recoverable reserves of the United States, as of January 1, 1960 , total 830,145 million tons, based on the assumption that half of the coal reserves in the ground will be lost in mining and half will be recovered. The distribution of the remaining and recoverable reserves by rank is shown below.

Remaining and recoverable coal reserves of the United States, Jan. 1, 1960

\begin{tabular}{|c|c|c|c|}
\hline \multirow{2}{*}{ Rank } & \multirow{2}{*}{$\begin{array}{l}\text { Estimated total } \\
\text { reserves remain. } \\
\text { ing in the ground, } \\
\text { Jan. 1, 1960 } \\
\text { (millions of short } \\
\text { tons) }\end{array}$} & \multicolumn{2}{|c|}{$\begin{array}{l}\text { Estimated recoverable reserves, } \\
\text { Jan. 1, 1960, assuming } 50 \text { percent } \\
\text { recovery in- }\end{array}$} \\
\hline & & $\begin{array}{c}\text { Millions of short } \\
\text { tons }\end{array}$ & $\begin{array}{l}\text { Quadrillions of } \\
\text { British thermal } \\
\text { units }\end{array}$ \\
\hline $\begin{array}{l}\text { Bituminous coal } \\
\text { Subbituminous coal } \\
\text { Lignite. } \\
\text { Anthracite and semianthracite. }\end{array}$ & $\begin{array}{r}760,554 \\
436,812 \\
447,596 \\
15,328\end{array}$ & $\begin{array}{r}380,277 \\
218,406 \\
223,798 \\
7,664\end{array}$ & $\begin{array}{l}9,963 \\
4,150 \\
2,999 \\
195\end{array}$ \\
\hline Total & $1,660,290$ & 830,145 & 17,307 \\
\hline
\end{tabular}


The reserves in 15 States have been classified in considerable detail according to thickness of beds, thickness of overburden, and relative abundance of reliable information available for making estimates. These 15 States represent several coal provinces and contain about half of the total estimated reserves in the United States. An analysis of the distribution of reserves in these States shows that 6 percent of the total is measured reserves in beds 28 inches or more thick and less than 1,000 feet below the surface; and 19 percent is Indicated reserves within the same limit of thickness and less than 2,000 feet below the surface. ${ }^{1}$ The remaining 75 percent is inferred reserves, reserves in thin beds, and reserves 2,000 to $3,0,00$ feet below the surface.

The large percentage of inferred reserves obviously includes some coal in thick beds, for which detailed information-is lacking. Although based accurately on the data now available, the distribution percentages are subject to considerable change as new work is completed, particularly in the transfer of reserves from the indicated and inferred categories to the measured category. The flgures serve, however, to indicate the present state of knowledge of the Nation's coal reserves, and they point to the need for additional geologic mapping and exploration.

A comparison on a uniform British thermal units basis of reserves of coal and other fuels shows that coal constitutes 68 percent of the total estimated recoverable fuel reserves, and that petroleum and natural gas together constitute about 16 percent. The remaining 16 percent is oil in oil shale, which is not currently used as fuel. The disparity in reserves is further emphasized by the fact that petroleum and natural gas together are being produced and consumed at a rate more than twice that of coal.

The total recoverable reserves of coal, as of January 1, 1960, are 1,442 times the recent average annual production. Even assuming a great increase in the rate of coal production, these reserves still will last many generations. On any basis of analysis the coal reserves of the United States are very large and give assurance that the fuel needs of the Nation can be met in any contingency for many decades to come.

\section{INTRODUCTION}

The industrial supremacy of the United States is based largely on the abundance and accessibility of the three mineral fuels-coal, petroleum, and natural gas - of which coal is by far the most abundant source of energy. Although the total reserves of coal in the United States are known only in a general way, and the total reserves of petroleum and natural gas are largely undefined and may ultimately prove to be much larger than present estimates suggest, it appears on the basis of information currently available that the recoverable reserves of coal contain more than four times the energy of the combined reserves of petroleum and natural gas. Although apparently less abundant, petroleum and natural gas do not at present differ greatly in cost from coal, and they are generally more convenient to use. As a result, the fourfold increase in use of energy in the United States that has taken place during the last 50 years has been met largely by an increase in the use of petroleum and

1 Measured reserves 1,000 to 2,000 feet below the surface are insignificant. 
natural gas. The increase has been accelerated in recent years by the extraordinary demands of World War II and by a considerable increase both in population and in per capita use of energy.

The increase in use of petroleum and natural gas has been accompanied by a comparable increase in both proved and ultimate reserves of these fuels, which attest to the ability of the petroleum industry to supply an increased demand throughout the foreseeable future. Nevertheless, petroleum and natural gas are nonrenewable resources. Like other mineral resources, the ultimate reserves of these fuels have finite limits. Regardless of where the limits may be established, the continued upward trend in use serves as a reminder that these fuels will not continue indefinitely in their present abundance.

It seems most likely that over the years the recovery of petroleum and natural gas will gradually become more difficult and expensive. At such time, the large consumers of energy will turn to the most economical fuel available, and coal as an economical, abundant, and highly versatile source of energy will be in a favored position.

Although coal is abundant and widespread in the United States (figs. 1 and 8), reserves of coal also have limits. In the extensively mined eastern coal fields, it is becoming increasingly difficult to locate new areas containing thick beds of high-rank and high-quality coal. This is particularly true for low-volatile bituminous coal, which is the most important ingredient in the manufacture of coke and which constitutes only about 1 percent of the total reserves. Furthermore, a large part of the total reserves of coal in the United States consists of coal of lignite and subbituminous ranks, which yield less heat than bituminous coal. Another large part is contained in thin beds that can be mined only with great difficulty and expense.

Considering the importance of coal in the present and future fuel economy, it is apparent that much more information is needed about the amount and distribution of coal in the United States than has been available in the past. Recognizing this need, the U.S. Geological Survey began in 1947 to expand the program of detailed geologic mapping in coal field areas, and simultaneously started the preparation of new State-by-State summary estimates of coal reserves. Several State geological surveys have embarked on reserve programs in the respective States. The increasing volume of geologic data available on the occurrence of coal, and the detailed and careful methods now employed in calculating and classifying coal reserves, already permit a much more reliable and useful estimate for the coal reserves of the United States than has previously been available, although much detailed and summary work remains to be done to improve the accuracy and completeness of the estimate. 


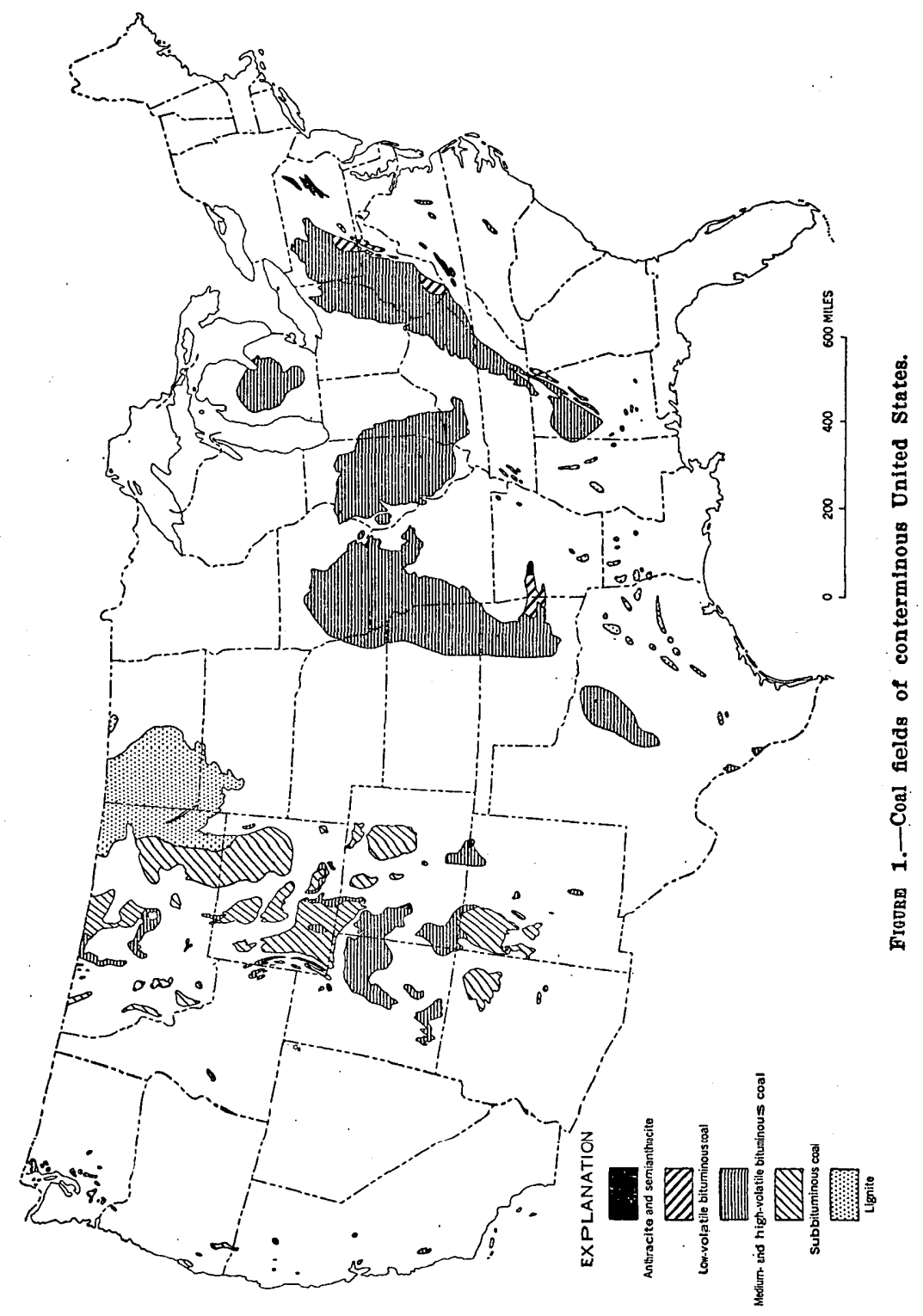


This third report of progress on the results of the program to reestimate the coal reserves of the United States supersedes "Coal Resources of the United States, a Progress Report, October 1, 1953," published in 1954 as U.S. Geological Survey Circular 293.

\section{ACKNOWLEDGMENTS}

The writer has drawn heavily upon material used in the previous edition of this report, of which Louise R. Berryhill and Dorothy A. Taylor Sandberg were joint authors. He has also received advance abstracts and summary tables of reserves from authors of many State coal reserve reports that were in preparation or in press at the time the present report was being prepared. The list of these contributors includes: Farrell F. Barnes (Alaska), Russell A. Brant (Ohio), William C. Culbertson (Alabama), Edward T. Luther (Tennessee), John W. Huddle (Kentucky), and E. R. Landis (Colorado). The chapter on minor elements in coal was prepared with help from Norman N. Denson and George N. Pipiringos. The coal reserves tables were prepared with the invaluable assistance of Flora $K$. Walker. This substantial volume of material and assistance has greatly facilitated preparation of the present report.

\section{STATUS OF AVAILABLE INFORMATION}

Estimates of coal reserves are based largely on detailed geologic maps showing the outcrops and correlations of individual coalbeds and on accompanying geologic reports giving detailed measurements of coal thickness. This information is augmented locally by data from exploratory and development drilling and from operating mines. Unfortunately, many coal-bearing areas in the United States have not been mapped geologically; many others have been mapped only in reconnaissance; and few have been prospected other than along the outcrops of the beds. In States where recent reserve estimates have been prepared, many large areas known to be coal bearing have been omitted from consideration for want of information. In Colorado, for example, 75 percent of the coal-bearing area was thus omitted; in Wyoming, 53.5 percent was omitted; and in Montana, 9.3 percent was omitted. Even in the eastern fields where information is generally considered to be more abundant, much of the geologic mapping dates from the period 1900-20 and does not provide the data necessary for a modern inventory of reserves. Progress toward full knowledge of the coal reserves of the United States depends, therefore, upon an active program of detailed geologic mapping and exploratory drilling. Such detailed work is in progress on a modest scale by the U.S. Geological Survey and several State agencies. 
Based as they are upon accumulated detailed information that is obtained only by the laborious processes of mapping outcrops of coalbeds and drilling holes to test the coal thickness, the present estimates of coal reserves are only provisional estimates and are subject to change as mapping, prospecting, and development are continued. These estimates are valuable, however, in showing the quantitative distribution of reserves, in selecting areas favorable for further exploration or development, and in planning industrial expansion.

The first considered estimate of the total coal reserves of the United States was prepared by M. R. Campbell, of the Geological Survey, and published at various times in the period before 1929 (Campbell, 1917, 1922, 1929). For more than 20 years this estimate served as the principal reference on our National coal reserves and was republished with only minor modifications by other individuals and organizations. Campbell's generalized estimate was necessarily based on many broad assumptions concerning the thickness and lateral extent of coalbeds in areas for which little geologic data were then available. The estimate included all coal in the ground in beds more than 14 inches thick under less than 3,000 feet of overburden, without attempting to distinguish between reserves of thick, easily accessible coal and reserves of thin, deeply buried coal.

In the period 1928-47, new and more conservative estimates of coal reserves in Pennsylvania, West Virginia, and Kansas were prepared by the geological surveys of the respective States. ${ }^{2}$ These estimates were more detailed than the older estimates and were correspondingly more useful.

In the current U.S. Geological Survey program to reestimate the coal reserves of the United States, which began in 1947, primary emphasis has been placed on the amounts of coal in many separate categories according to characteristics of the coal and thickness of overlying rocks because of the obvious need for such classified information in the proper utilization of reserves. Prepared as part of this program to date are new detailed estimates of coal reserves in 14 States-Alabama, Arkansas, Colorado, Indiana, eastern Kentucky, Michigan, Montana, New Mexico, North Carolina, North Dakota, Oklahoma, South Dakota, Virginia, and Wyoming-which have been presented previously in separate publications, or which are in advanced stages of preparation or publication. Also prepared to date are new provisional estimates of reserves in 5 States-Alaska, Georgia, Maryland, Oregon, and Utah-which are presented or cited herein. In this same period the State Geological Surveys of Illinois, Ohio, Tennessee, and Texas (lignite only) have published new re-

2 References cited under discussion of reserves in individual States. 
ports on reserves in their respective States; and the U.S. Bureau of Mines has published reports on reserves in 44 counties in Pennsylvania, West Virginia, eastern Kentucky, and Tennessee.

The estimates included in this report are based on reserve figures from these varied sources, which are not strictly comparable. (See tables 1 and 2, fig. 2.) In particular, the estimates for Iowa, Missouri, Texas (bituminous coal), and Washington, which were prepared by or under the direction of M. R. Campbell before 1928, were based on more generous assumptions than recent estimates, and allowance should be made for this fact in considering them.

TABLE 1.-Coal reserves of the United States, January 1, 1960, by rank

[In mullions of short tons]

\begin{tabular}{|c|c|c|c|c|c|c|}
\hline \multirow[b]{2}{*}{ State } & \multirow{2}{*}{$\begin{array}{l}\text { Date of } \\
\text { publica- } \\
\text { tion of } \\
\text { estimate. }\end{array}$} & \multirow{2}{*}{$\begin{array}{l}\text { Estimated } \\
\text { original } \\
\text { reserves }\end{array}$} & \multicolumn{2}{|c|}{$\begin{array}{l}\text { Reserves depleted } \\
\text { to Jan. } 1,1960\end{array}$} & \multirow{2}{*}{$\begin{array}{l}\text { Reminining } \\
\text { reserves, } \\
\text { Jan. 1, 1960 }\end{array}$} & \multirow{2}{*}{$\begin{array}{c}\text { Recover- } \\
\text { able } \\
\text { reserves, } \\
\text { Jan. 1, } \\
1960 \text {, as- } \\
\text { suming } \\
50 \\
\text { percent } \\
\text { recovery }\end{array}$} \\
\hline & & & $\begin{array}{l}\text { Produc- } \\
\text { tion ? }\end{array}$ & $\begin{array}{l}\text { Produc- } \\
\text { tion plus } \\
\text { loss in } \\
\text { mining } 2\end{array}$ & & \\
\hline
\end{tabular}

\begin{tabular}{|c|c|c|c|c|c|c|}
\hline \multicolumn{7}{|c|}{ Bituminous coal } \\
\hline ALABAMA 8 & (4). & 013,781 & 023 & 046 & 13,708 & 6.854 \\
\hline ALASKA & (7) & 21,401 & 5 & 10 & 21,391 & 10,696 \\
\hline ARKANAAS-: & 1960 & 1,816 & 87 & 174 & 1,642 & 821 \\
\hline OLORADO. & 1959 & 63,203 & 384 & 768 & 62,435 & 31,218 \\
\hline GEORGIA... & 1953 & 100 & 12 & 24 & 76 & \\
\hline LINOIS..... & 1953 & 8137,329 & $\because 474$ & 0948 & 136,381 & 68,190 \\
\hline DIANA -.. & 1953 & 37,293 & 1,148 & 2,296 & 34,997 & 17,499 \\
\hline Iowa $10 \ldots$ & 1009 & 29,160 & 357 & 714 & 28,446 & 14,223 \\
\hline KANSAS.... & 1851 & 820,774 & 013 & 026 & 20,748 & $\begin{array}{l}10,374 \\
10\end{array}$ \\
\hline KENTUCK $Y_{-}$ & (4) & 72,318 & 2,646 & 5,292 & 67,026 & 33,513 \\
\hline MARYLAND... & 1953 & 81,200 & 06 & 12 & 1,188 & 594 \\
\hline MI & 1950 & 297 & 46 & 92 & 205 & 102 \\
\hline $\mathbf{M}$ & 1913 & 79,362 & 287 & 574 & 78,788 & 39,394 \\
\hline MONTANA & 1949 & 2,363 & 32 & 64 & 2,299 & 1,149 \\
\hline NEW MEXICO & 1950 & 10,948 & 91 & 182 & 10,766 & 5,383 \\
\hline NORTH CAROLINA & 1955 & 112 & 1 & 2 & 110 & 55 \\
\hline OHIO.... & 1960 & 46,488 & 2,052 & 4,104 & 42,384 & 21,192 \\
\hline OKLAHOMA... & 1957 & 3,673 & 180 & 360 & 3,313 & 1,656 \\
\hline OREG & 1955 & 20 & 0 & 0 & 20 & 10 \\
\hline VANIA. & 1928 & 75,093 & 8,283 & 16,566 & 58,527 & 28,263 \\
\hline & 1959 & 111,912 & 126 & 1212 & 1,900 & 950 \\
\hline $\mathrm{Te}$ & 1800 & 8,000 & 11 & & 7,978 & 3,989 \\
\hline TTAH-... & (7) & 28,222 & 257 & & 27,708 & 13,854 \\
\hline VIRGINIA. & 1952 & 11,696 & 772 & 1,544 & 10,152 & $\begin{array}{r}13,804 \\
5,076\end{array}$ \\
\hline Washington & 1929 & 11,413 & 129 & 258 & 11,155 & 5.078 \\
\hline WEST VIRGINIA & 1940 & 116,618 & 6,369 & 12,738 & 103,880 & $\begin{array}{r}5,578 \\
51,940\end{array}$ \\
\hline WYOMING & 1950 & 13,235 & 261 & 522 & 12,713 & 6,357 \\
\hline Other Stat & & 620 & 1 & & 618 & 309 \\
\hline Total. & & 808,420 & 23,933 & 47,866 & 760,554 & 380,277 \\
\hline \multicolumn{7}{|c|}{ Subbituminous coal } \\
\hline & (i) & 1471,136 & 8 & 16 & 71,120 & 35,560 \\
\hline co & 1959 & 18,492 & 116 & 232 & 18,260 & 8,130 \\
\hline MONTANA... & 1949 & 132,151 & 337 & 274 & 131,877 & 65,939 \\
\hline NEW MEXICO.. & 1950 & 50,801 & 33 & 66 & 50,735 & 25,368 \\
\hline OREGON & 1855 & 180 & 3 & 6 & 174 & 87 \\
\hline ITAH & $(7)$ & 156 & 3 & 6 & & 75 \\
\hline Washington & 1928 & 52,442 & 20 & 40 & 52402 & 26.201 \\
\hline & 1958 & & & 280 & 02,402 & 20.201 \\
\hline Other States is & & $\begin{array}{r}108,065 \\
4,065\end{array}$ & 191 & $\begin{array}{r}282 \\
8\end{array}$ & $\begin{array}{r}0,057 \\
4,057\end{array}$ & $\begin{aligned} 54,018 \\
2,028\end{aligned}$ \\
\hline Total & $\ldots . .$. & 437,742 & 465 & 930 & 436,812 & 218,400 \\
\hline
\end{tabular}


TABLE 1.-Coal reserves of the United States, January 1, 1960, by rank-Continued [In millions of short tons]

\begin{tabular}{|c|c|c|c|c|c|c|}
\hline \multirow{2}{*}{ State } & \multirow{2}{*}{$\begin{array}{l}\text { Date of } \\
\text { publica- } \\
\text { tion of } \\
\text { estimate }\end{array}$} & \multirow{2}{*}{$\begin{array}{l}\text { Estimated } \\
\text { original } \\
\text { reserves }\end{array}$} & \multicolumn{2}{|c|}{$\begin{array}{c}\text { Reserves depleted } \\
\text { to Jan. 1, } 1960\end{array}$} & \multirow{2}{*}{$\begin{array}{c}\text { Remaining } \\
\text { reserves, } \\
\text { Jan. 1, } 1960\end{array}$} & \multirow{2}{*}{$\begin{array}{c}\text { Recover- } \\
\text { able } \\
\text { reserves, } \\
\text { Jan. 1, } \\
1960 \text {, as- } \\
\text { suming } \\
50 \\
\text { percent } \\
\text { recovery }\end{array}$} \\
\hline & & & $\underset{\text { tion }^{1}}{\text { Produc- }}$ & $\begin{array}{l}\text { Produc- } \\
\text { tion plus } \\
\text { loss in } \\
\text { mining } 2\end{array}$ & & \\
\hline \multicolumn{7}{|c|}{ Lignite } \\
\hline $\begin{array}{l}\text { ALABAMA } \\
\text { ALASKA } \\
\text { ARKANSAS } \\
\text { KANSAS } \\
\text { MONTANA } \\
\text { NORTH DAKOTA } \\
\text { OKLAHOMA } \\
\text { SOUTH DAKOTA } \\
\text { TEXAS } \\
\text { WaShIngton } \\
\text { WYOMING } \\
\text { Other States }{ }^{77}\end{array}$ & $\begin{array}{l}(4) \\
(7) \\
1960 \\
1952 \\
1949 \\
1953 \\
1957 \\
1952 \\
1955 \\
1928 \\
1950\end{array}$ & $\begin{array}{lr} & 20 \\
(14) & \\
& 350 \\
(16) & \\
87,533 \\
350,910 \\
(16) & \\
2,033 \\
7,070 \\
(14) & \\
(14) & \end{array}$ & $\begin{array}{r}0 \\
0 \\
0 \\
2 \\
96 \\
0 \\
1 \\
84 \\
2\end{array}$ & $\begin{array}{r}0 \\
0 \\
0 \\
4 \\
192 \\
0 \\
2 \\
168 \\
4\end{array}$ & $\begin{array}{r}20 \\
350 \\
87,529 \\
350,718 \\
2,031 \\
6,902 \\
46\end{array}$ & $\begin{array}{r}10 \\
175 \\
43,765 \\
175,359 \\
1,015 \\
3,451 \\
23\end{array}$ \\
\hline Total & & 447,966 & 185 & 370 & 447,596 & 223,798 \\
\hline \multicolumn{7}{|c|}{ Anthracite and semianthracite } \\
\hline $\begin{array}{l}\text { ALASKA } \\
\text { ARKANSAS } \\
\text { COLORADO } \\
\text { NEW MEXICO } \\
\text { PENNSYLVANIA } \\
\text { VIRGINIA } \\
\text { Washington }\end{array}$ & $\begin{array}{l}(7) \\
1960 \\
1959 \\
1950 \\
1945 \\
1952 \\
1928\end{array}$ & $\begin{array}{r}2,101 \\
456 \\
90 \\
6 \\
22,805 \\
355 \\
23\end{array}$ & $\begin{array}{r}12 \\
6 \\
1 \\
5,225 \\
10\end{array}$ & $\begin{array}{r}24 \\
12 \\
2 \\
10,450 \\
20\end{array}$ & $\begin{array}{r}2,101 \\
432 \\
78 \\
4 \\
12,355 \\
335 \\
23\end{array}$ & $\begin{array}{r}1,050 \\
216 \\
39 \\
2 \\
6,178 \\
168 \\
11\end{array}$ \\
\hline Total..... & 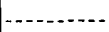 & 25,836 & 5,254 & 10,508 & 15,328 & 7,664 \\
\hline Total, all ranks. & -........... & $1,719,964$ & 1829,837 & 59,674 & $1,660,290$ & 830,145 \\
\hline
\end{tabular}

1 Production, 1800 through 1885, from "The first century and a quarter of American coal industry,"-by H. N. Eavenson; privately printed, Pittsburgh, 1942; production, 1886 through 1923, from U.S. Geological Survey Mineral'Resources, annual volumes; production, 1924 through 1957, from U.S. Bureau of Mines, Minerals Yearbook, annual volumes, augmented for some States by records of State mine inspectors; production, 1958, from U.S. Bureau of Mines, Mineral Market Summary 2974, Sept. 9, 1959; production, 1959, from U.S. Bureau of Mines weekly coal reports and partly estimated.

2 Assuming past losses equal past production.

3 Reserve estimates of States in capital letters supersede earlier estimates of M. R. Campbell.

New estimate from report in preparation or in press. See text.

$\checkmark$ Remaining reserves, Jan. 1, 1958.

6 Production 1958 and 1959 only.

7. New estimate presented for first time in this report.

8 Remaining reserves, Jan. 1, 1950.

10 Reserve estimates of States in lowercase letters were prepared by or under the direction of $M$. R.

Campbell before 1928 .

it Remaining reserves, Jan. 1, 1958.

12 Estimated production 1950 ony.

13 ARIZONA, CALIFORNIA, Idaho, Nebraska, and Nerada.

16 Small reserves of lignite in beds generally less than $30 \mathrm{in}$. thick.

17 CalirnRNIA, Idaho, Louisiana, and Nevada.

18 Less than total recorded production of about 34.8 billion tons. See footnotes $5,6,8, \theta, 11$, and 12 . 


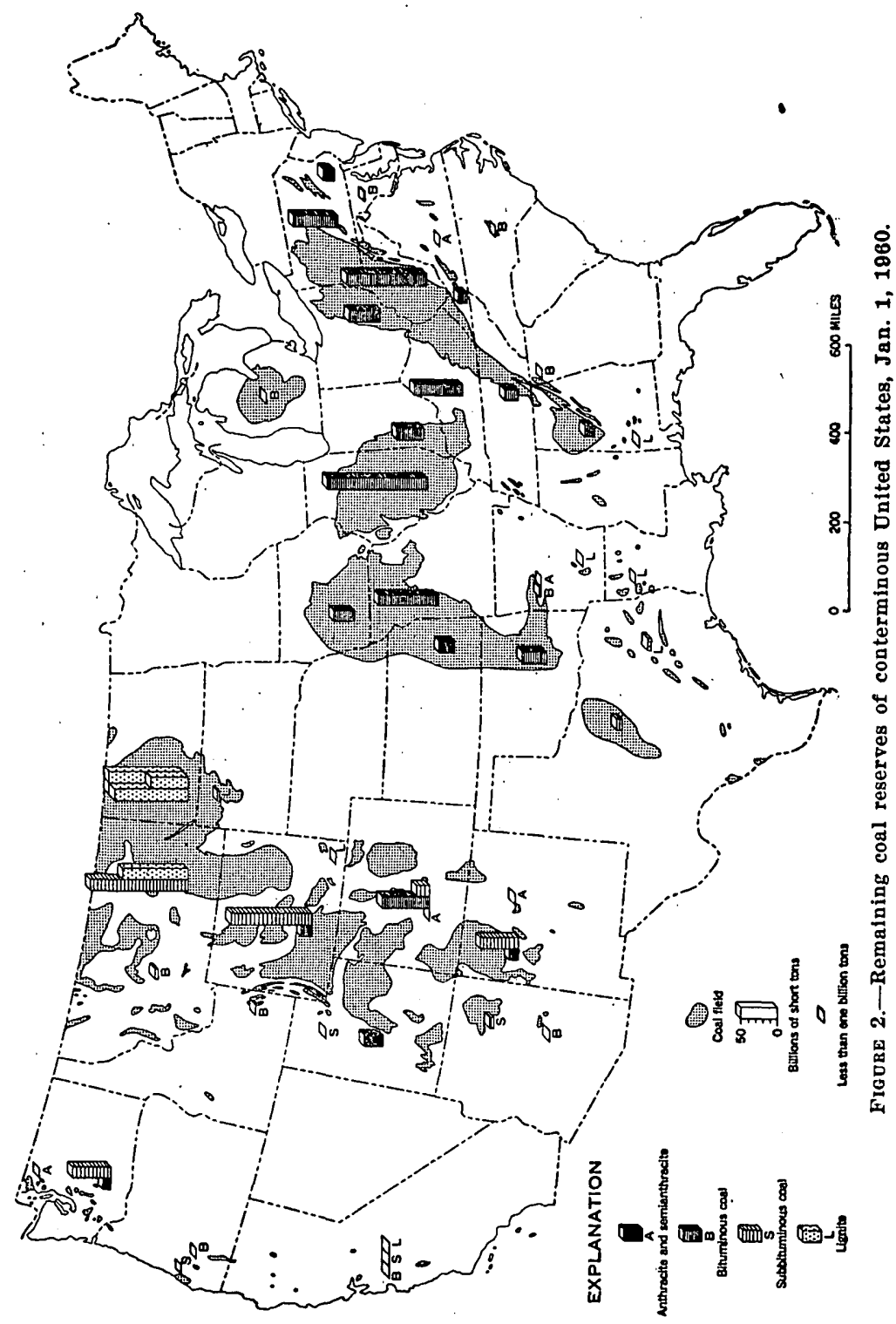




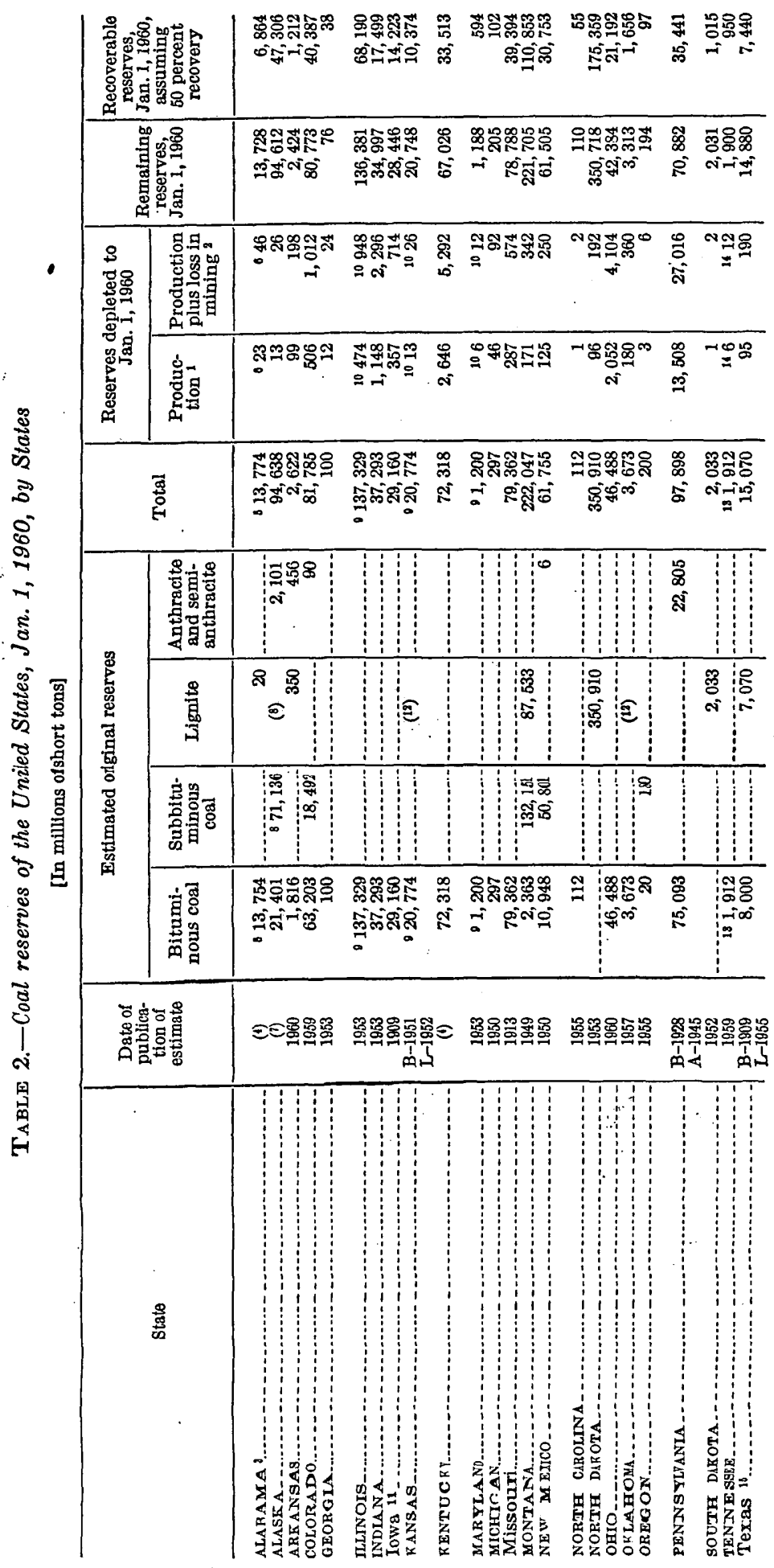




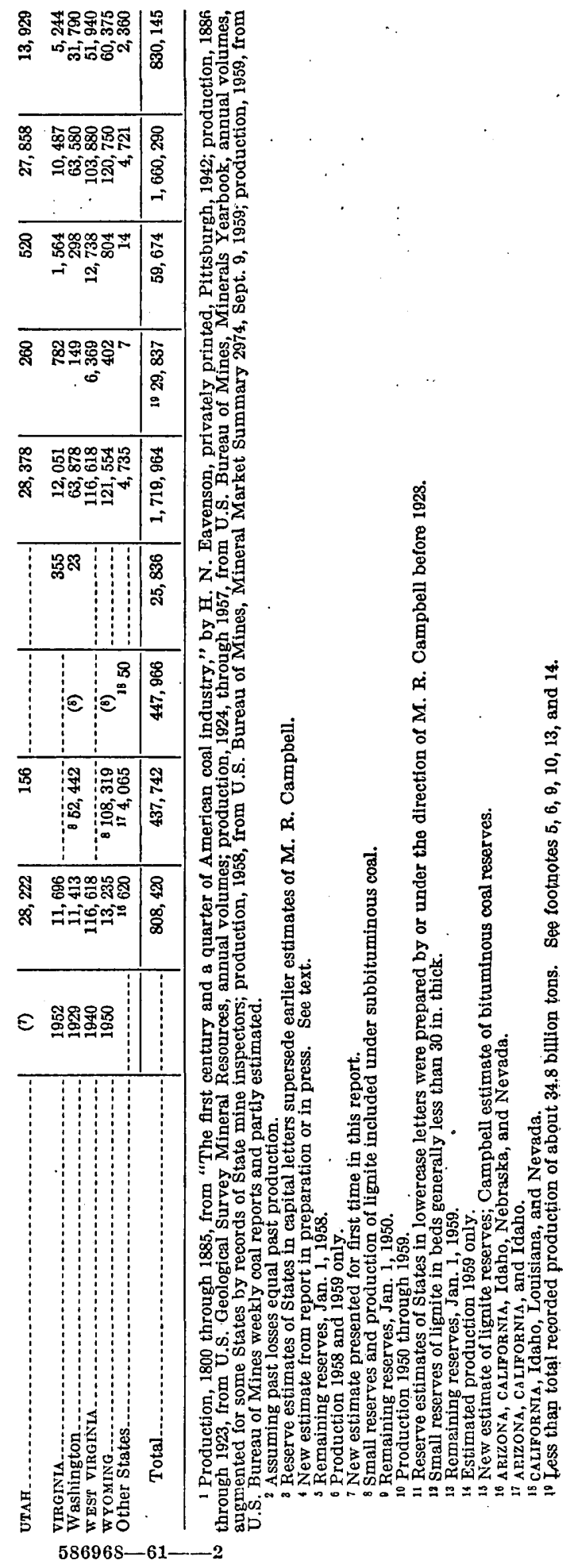




\section{METHODS OF PREPARING AND REPORTING COAL-RESERVE ESTIMATES}

In preparing statewide estimates of coal reserves, all available information is first gathered together and recorded on individual coalbed maps. Sources of information include the publications and records of the U.S. Geological Survey and State geological surveys, maps and drill records of coal mining companies, information in the files of State mine inspectors and railroad companies, records of exploration for petroleum and natural gas, records of water-well drilling companies, and occasionally private records obtained from individuals. To translate this information accumulated from geologic observation, mining, and drilling into estimates of tonnage, a series of definitions and standardized procedures must be employed.

First, two cutoff points must be established-one at the minimum thickness of coal included in the estimate, and the other at the maximum thickness of overburden allowed above the coal. A very conservative estimate may include only reserves in thick beds and under slight overburden -in other words, reserves that could be recovered profitably under current mining conditions. A more inclusive estimate, on the other hand, may consider thinner, more impure, and more deeply buried coal as recoverable by improved methods when more easily mined deposits have been exhausted.

Next, the weight or specific gravity of the coal must be determined or assumed, and where the continuity of a coalbed is unknown a method must be selected to estimate its probable extent, based on the available outcrop, mine, or drill data.

The way in which these and other factors are treated can vary greatly with individual estimators, and the results of such varied treatment are apparent in the estimates for several States. For this reason, an estimate of coal reserves has meaning only when considered in relation to the methods used in obtaining it.

To produce reasonably uniform results in preparing coal-reserve estimates, the U.S. Geological Survey has adopted a set of definitions and standardized procedures for the guidance of Survey coal geologists. These definitions and procedures, which are discussed in the following paragraphs, were prepared jointly by members of the Geological Survey and the Bureau of Mines, and include recommendations of the National Bituminous Coal Advisory Council.

\section{RESERVES VERSUS RESOURCES}

In discussing estimated quantities of coal in the ground, it is necessary to employ a single general term such as "reserves" or "resources" to refer to the supply available for present and future use or to refer to one or more, or all of the many categories of coal that 
have been established. The word "reserves" has been selected for this purpose, primarily because it has long been associated with estimates of quantities of coal, because it carries the connotation of measured quantities, and because it does not imply the total quantity that might ultimately be found. The companion word "resources" has been rejected because it has come to mean undefined and unspecified total quantities.

In the metal mining industry the word "reserves" normally means ore of immediate or very near-term economic interest. Many writers have urged that this usage be applied as strictly as possible to all mineral commodities, and that the term "resources" be used to connote the total but unspecified quantity of material that may ultimately be found. Blondel and Lasky (1956) have recently proposed an equation that expresses this relation very well:

\footnotetext{
Resources $=$ reserves + marginal resources + submarginal resources + latent resources.
}

It is impossible to use the two words "reserves" and "resources" with these definitions in this report because coal is very. widespread and abundant in the United States, and occurs in a variety of conditions that require for discussion a detailed breakdown according to selected physical and chemical characteristics of the coal and associated rocks. These characteristics are summarized in the following outline, and will be discussed in more detail in subsequent pages:

Rank (5 categories)

Thickness of beds ( 3 categories)

Thickness of overburden ( 3 categories)

Relative reliability of estimates (3 categories).

This breakdown yields 5 by 3 by 3 by 3 , or 135 possible categories. With this comprehensive classification system it is necessary to emphasize the physical and chemical boundaries of the categories, and in so doing the need remains for but a single term that can be used to refer to the categories individually and collectively. Although either word, "reserves" or "resources," might be redefined for this specific purpose, the selected word "reserves" seems to be the most appropriate. As used in this report, therefore, the word "reserves" means estimated quantities of coal in the ground within stated limits of minimum bed thickness and maximum overburden thickness. As thus defined, the word has no direct economic connotation, although the selected limits of the various reserve categories have economic application.

It must be emphasized that, in total, the many categories of coal described in this report cover "reserves" plus "marginal resources" and probably extend into "submarginal resources" as envisioned by Blondel and Lasky, and thus probably cover roughly half of their total resource spectrum. 
CLASSIFICATION ACCORDING TO CHARACTERISTICS OF THE COAL RANK OF COAL

Coal is classified by rank according to percentage of fixed carbon and heat content, calculated on a mineral-matter-free basis. As shown in figure 3 , the percentage of fixed carbon and the heat content, except in anthracite, increase from the lowest to the highest rank of coal as the percentages of volatile matter and moisture de-
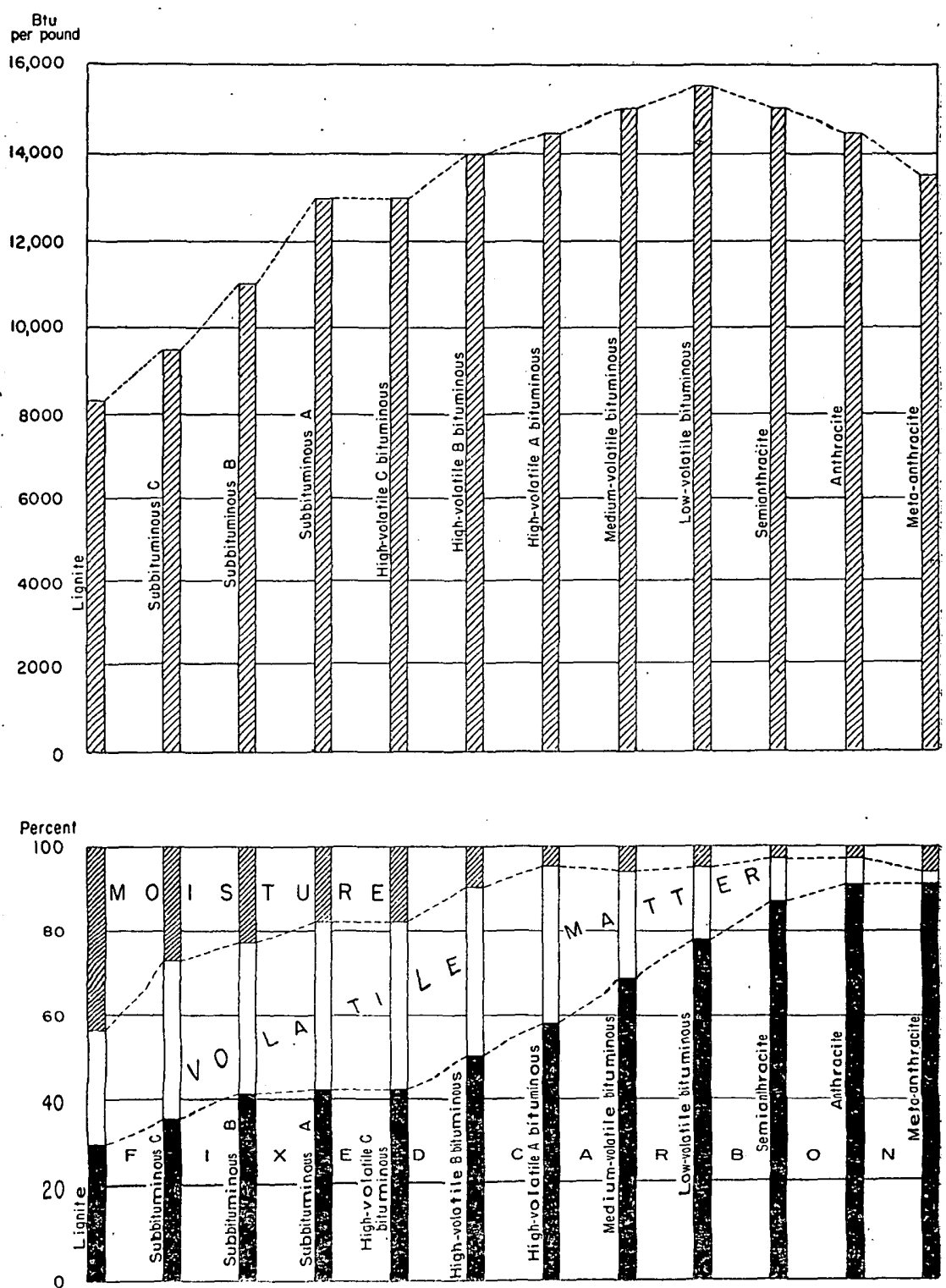

Frgure 3.-Heat value of coal of different ranks compared to proximate analyses. 
crease. This change took place progressively during the slow process by which plant material deposited in swamps and marshes in the geologic past was transformed into coal. The lower layers of plant material in the swamps were first compacted under successive layers of vegetation. Later, as marine or continental deposits covered the coal swamps, the accumulated weight of sediment further compressed the plant material and caused a progressive decrease in the amounts of volatile matter and moisture. It has been estimated that a foot of bituminous coal contains plant material accumulated over a period of several centuries. The coal-forming process was speeded up or intensified locally by deformation of the coal-bearing sediments or by heat from nearby masses of intrusive igneous rock.

Rank of coal is thus a function of weight of original overburden, age, and local deformation, and is a way of expressing successive stages in the formation of coal. It is quite independent of grade, or quality, which is in part a function of the amount of ash and sulfur in the coal.

The standard classification of coal by rank in use in the United States is that established by the American Society for Testing Materials (1954). This classification, which is shown in table 3 , is used uniformly in classifying all coal-reserve estimates. As coals of different rank are adaptable to different uses, rank is the major basis of differentiation used on figures 1 and 2 and in tables 1 and 2 .

Most of the tables and illustrations in this report show reserves of all ranks of coal in short tons as computed. In terms of ultimate usefulness, however, comparison of the reserves of lignite and subbituminous coal, which have relatively low heat values, with reserves of bituminous coal and anthracite, which have higher heat values, can best be made on a uniform Btu basis. Such a comparison is presented in figure 4 , which shows the remaining reserves in each State as of Jan. 1, 1960, on both a tonnage and a Btu basis.

\section{GRADE OF COAL}

Coal is classified by grade, or quality, largely according to the content of ash, sulfur, and other deleterious constituents. Thus far in work on coal reserves it has not been possible to report on reserves in categories according to grade because the number of available coal analyses is small as compared to the total reserves, and because the analyses are concentrated for the most part in areas of active mining and limited to the line of outcrop of certain key beds.

Although the definitions and procedures used in calculating coal reserves generally permit the inclusion of beds containing as much as 33 percent ash, very little coal of such high ash content is included in modern estimates, in part because of the natural con- 
TABLE 3.-Classification of coals by rank

[Explanation: FC, fixed carbon; VM, volatile matter; Btu, British thermal units. This classification does not include a few coals which have unusual physical and chemical properties and which come within the limits of fixed carbon on Btu of the high-volatile bituminous and subbituminous ranks. All of these coals. either contain less than 48 percent dry, mineral-matter-free fixed carbon or have more than 15,500 moist. mineral-matter-free Btu. From American Society for Testing Materials (1954)]

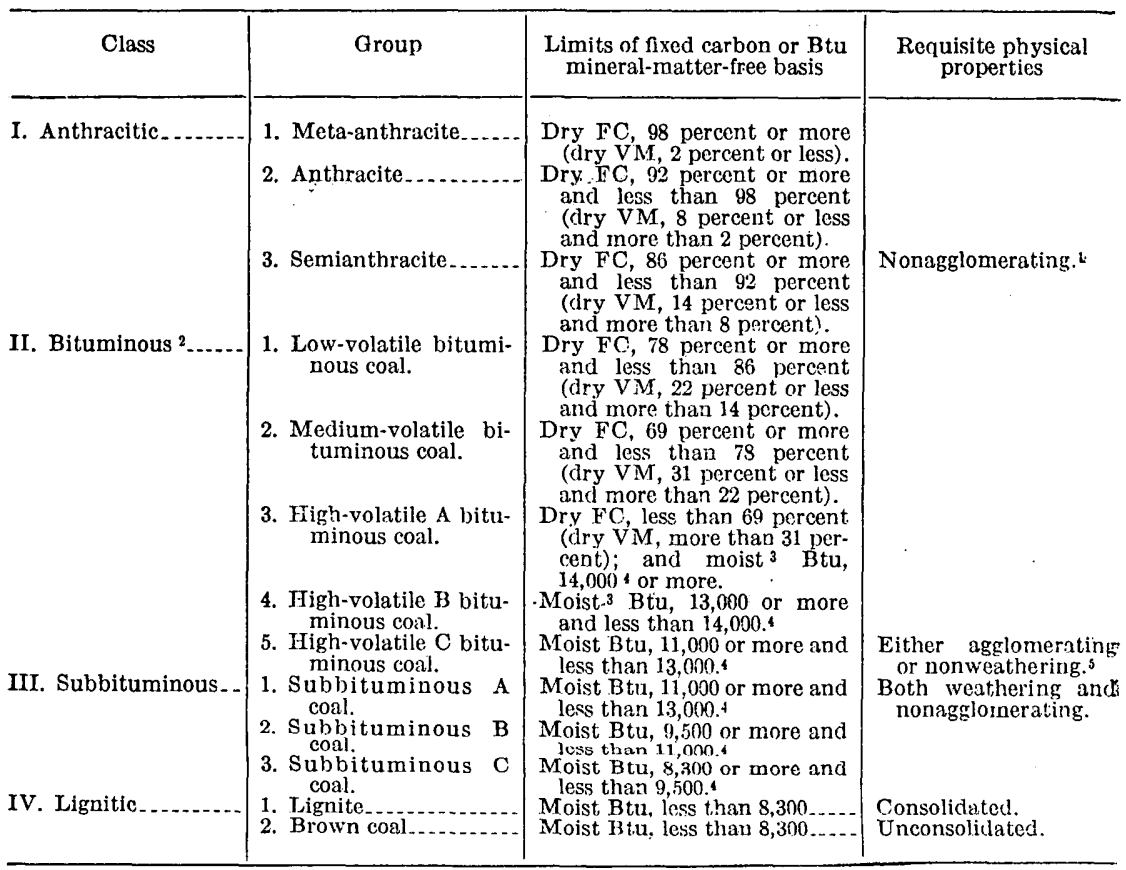

1 If agglomerating, classify in low-volatile group of the bituminous class.

2 It is recognized that there may be noncaking varieties in each group of the bituminous class.

3 Moist Btu refers to coal containing its natural bed moisture but not including visible water on the surface of the coal.

Coals having 69 percent or more fixed carbon on the dry, mineral-matter-free basis shall be classified: according to fixed carbon, regardless of $B$ tu

5 There are three varieties of coal in the high-volatile $C$ bituminous coal group. namely. variety 1 , agglomerating and nonweathering; variety 2 , agglomerating and weathoring; variety 3 , nonaggiomerating and nonweathering.

servatism of the estimators, and in part because all layers of parting and bone more than three-eighths of an inch thick are excluded in determining the thickness of the beds. On the other hand, reserve estimates obviously include beds containing higher ash and sulfur contents than most beds now being actively mined.

Fieldner and others (1942) have prepared a list of 642 typical mine, tipple, and delivered samples of coal from beds in all parts of the United States. In this list the ash contents range from 2.5 to 32.6 percent, and the average ash content is 8.9 percent. The sulfur contents range from 0.3 to 7.7 percent, and the average sulfur content is 1.9 percent.

The maximum ash and sulfur contents of beds included in the estimated reserves are probably about the same as the maximum figures shown in the list of typical analyzed samples, whereas the 


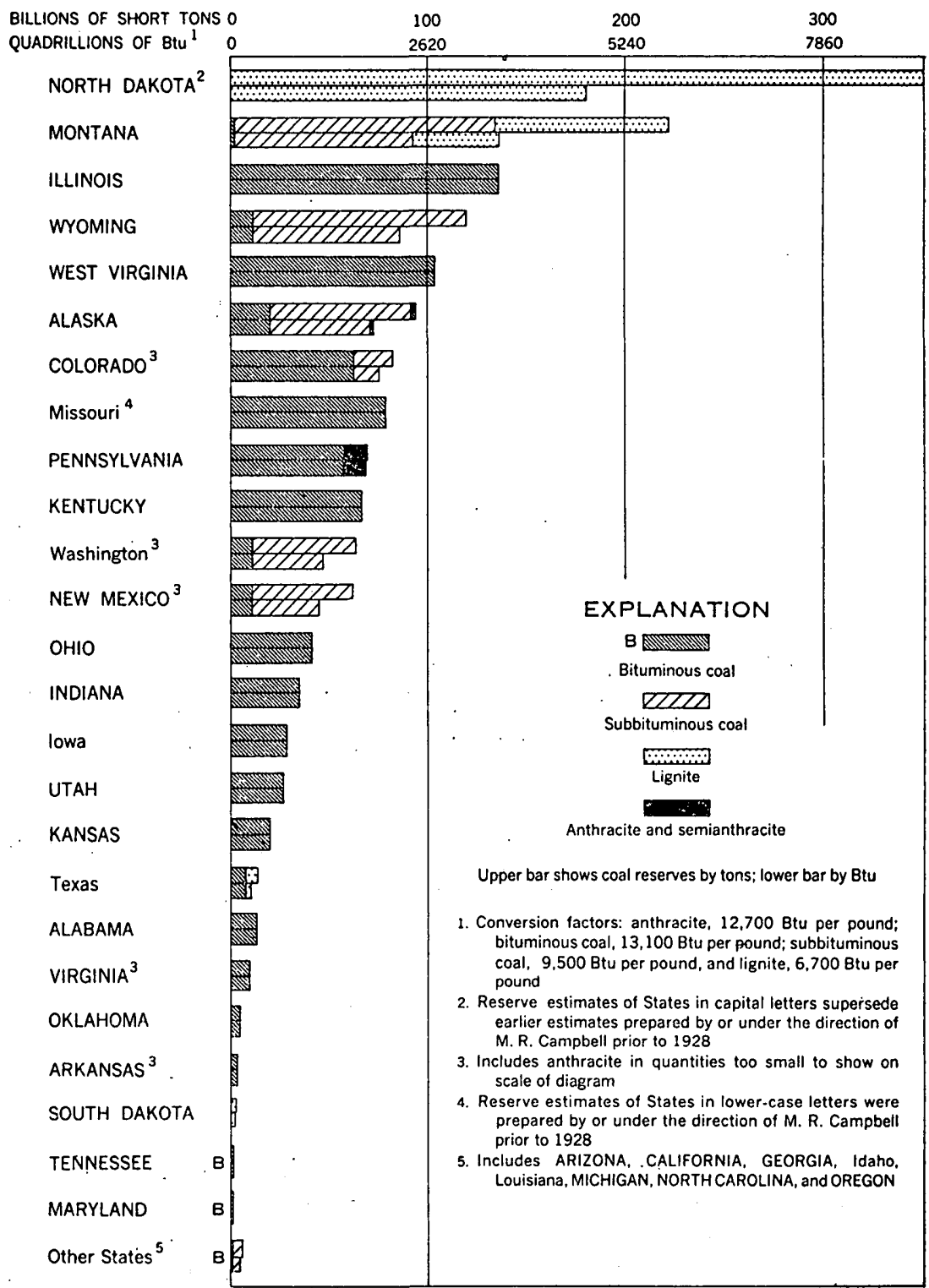

Fraurb 4.-Remalning coal reserves of the United States, Jan. 1, 1960, by States, according to tonnage and heat value.

average ash and sulfur contents of the estimated reserves are probably slightly higher than the averages derived from the list.

\section{WEIGHT OF COAT}

The weight of coal in the ground varies significantly with rank and with differences in ash content. The following values, however, 
conform closely to the average of the recorded specific gravities of coal in each of the four major rank categories:

\begin{tabular}{|c|c|c|c|}
\hline Rank & Speciflc gravity & $\begin{array}{c}\text { Tons per acre- } \\
\text { foot }\end{array}$ & $\begin{array}{c}\text { Tons per square } \\
\text { mile-foot }\end{array}$ \\
\hline $\begin{array}{l}\text { Anthracite and semianthracite } \\
\text { Bituminous coal } \\
\text { Subbituminous coal } \\
\text { Lignite_. }\end{array}$ & $\begin{array}{l}\text { 1. } 47 \\
\text { 1. } 32 \\
\text { 1. } 30 \\
\text { 1. } 29\end{array}$ & $\begin{array}{l}2,000 \\
1,800 \\
1,770 \\
1,750\end{array}$ & $\begin{array}{l}1,280,000 \\
1,152,000 \\
1,132,560 \\
1,120,000\end{array}$ \\
\hline
\end{tabular}

Where most precise data are not available, these values are assigned as the weight of the coal in the ground in all recent U.S. Geological Survey estimates of coal reserves.

Persons closely associated with individual mining operations often employ lower weight factors to allow for anticipated losses in mining. Such a practice is not suitable for use in a general report, however, for recoverability may vary greatly in different areas, in different beds, and with different methods of mining. The selected weight factors, therefore, are intended to yield reserves of coal in the ground without regard to ultimate recoverability.

\section{THICKNESS OF BEDS}

According to the standard procedures of the U.S. Geological Survey, coal reserves are calculated and reported by beds in categories of thickness as follows:

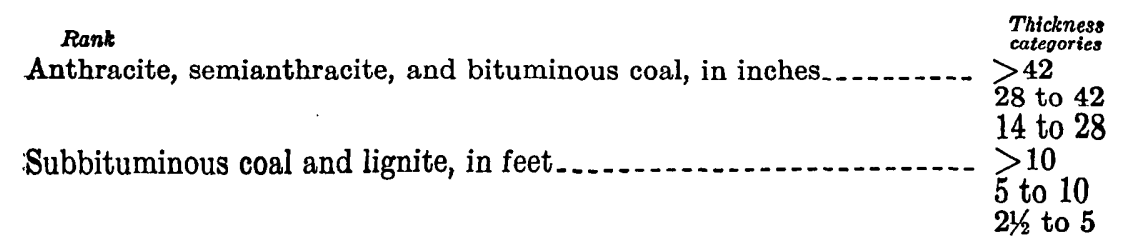

The thickness categories for anthracite and bituminous coal were selected to conform with present mining practices and past procodures in estimating reserves. The 14- to 28 -inch category represents coal that is suitable primarily for hand mining. Coal in this category is of little present economic interest and is, therefore, segregated in most estimates. The category is retained, however, because (a) prudence dictates that occurrences of marginal reserves of coal should be recorded for possible future use, just as marginal reserves of other useful minerals are recorded; (b) some coal in this category is mined; and (c) the information is obtained with little additional effort during work with the thicker coals and would be lost if ignored. The minimum of 14 inches also permits comparison with older estimates, which generally employed this same figure. 
The 28- to 42-inch category represents coal that can be mined using certain types of underground mechanical loading machinery.

The category of more than 42 inches represents coal that can be mined by all types of mechanical cutting and loading machinery.

The thickness categories for subbituminous coal and lignite are somewhat broader, to conform with occurrences of coal in these ranks and with present interest in such coal.

A fow recent estimates are classified into thickness categories of 14 to 24 inches, 24 to 36 inches, and more than 36 inches for bituminous coal. Other estimates made at various times in the past have used 18 inches as the minimum thickness for bituminous coal. Such differences are noted under the discussion of reserves in individual States as an aid in making comparisons between estimates.

The thickness of a coalbed is evaluated wherever possible by the use of isopach lines. Generally, however, the data are insufficient for this purpose, and average figures, which are weighted according to the approximate area of bed represented by each observation, are used. If the points of observation are not evenly spaced, the weighting is accomplished by assigning intermediate values for the thickness at places where data are needed to fill out a system of evenly spaced points. Where this procedure is followed to obtain the weighted average thickness along the outcrop of a persistent bed, the two end points of minimum thickness are also included in the average. Where the points of observation are fairly evenly spaced, as in an exploratory or development drilling program, a simple average is deemed sufficient.

Partings more than three-eighths of an inch thick are omitted in determining the thickness of individual beds. Beds and parts of beds made up of alternating layers of thin coal and partings are omitted if the partings make up more than half the total thickness or if the ash content exceeds 33 percent. Benches of coal of less than the minimum thickness stated, which lie above or below thick partings and which normally would be left in mining, are also omitted.

Occasionally, in older coal-reserve estimates, a formula termed "the modulus of irregularity" has been used to determine the probable minimum thickness of a coalbed. According to this formula, the probable minimum thickness is obtained by multiplying the average of the measurements of bed thickness by $\left(1-\frac{S D}{S}\right)$, in which $S$ is the sum of all the thickness measurements and $S D$ is the sum of the differences between each individual thickness measurement and the average of all the thickness measurements.

The modulus of irregularity was originally adopted by the U.S. Geological Survey as a mechanism in establishing the value of coal 
lands (Smith and others, 1913), but it is no longer used for this purpose. It was devised as a safeguard for the buyer of coal lands in areas where the coalbeds range in thickness within wide limits. As stated by Smith, computation of the thickness of the coal by using the modulus of irregularity permitted the

thickness of the coal under any tract of land to be considered as less than the average of the measurements. For while the coal is as likely to be just above the average as just below, and mathematically, is more likely to be just the average thickness than any other, yet a cautious buyer bargaining for coal would always want to discount the probability a little as a matter of safety.

The modulus of irregularity is no longer used in preparing estimates of coal reserves.

\section{AREAL EXTENT OF BEDS}

The areal extent of coalbeds included in U.S. Geological Survey reserve estimates is determined in several ways. Where the continuity of a bed is well established from maps of the outcrop, mine workings, and drill holes, the entire area of the known occurrence of the bed is taken, even though points of observation are widely spaced. Persistent beds that have been traced around a basin or spur are considered to underlie the area enclosed by the outcrop. Otherwise, the length of outcrop within the thickness limits listed is considered to determine the presence of coal in a semicircular area having a radius equal to half the length of the outcrop. The total area of coal is considered to extend beyond such a semicircle if mine workings or drill holes so indicate, in which case coal is considered to extend no more than 1 mile beyond the limiting point of information. An isolated drill hole too far removed to be incorporated in the area thus defined is considered to determine the area of coal extending for a maximum radius of half a mile around the hole.

Recent estimates by other agencies follow these or very similar procedures. Minor points of difference are noted under discussions of the various States.

The older estimates assumed much wider continuity for individual beds, and, in general, this is the major reason why the older estimates tend to be larger than the recent estimates.

\section{THICKNESS OF OVERBURDEN}

Wherever possible, coal-reserve data reported by the U.S. Geological Survey are divided into 3 major categories according to thickness, in feet, of overburden, as follows: 0 to 1,000, 1,000 to 2,000, and 2,000 to 3,000. In a few States where the overburden is thin, the reserves have been calculated in several subcategories within the 0 - to 1,000 -foot category, and in others, where the overburden is 
thicker or where information is inadequate, one or more of the major categories may be combined.

In Indiana, for example, where all the estimated reserves are less than 1,000 feet below the surface and where a large part of the production is by strip mining, the coal considered to be suitable for strip mining is divided into three categories as follows:

Overburden range (feet)

Thickness of. beds included

0 to $40 \ldots$

0 to 60

0 to 90

The remainder, which is considered suitable primarily for underground mining, is contained in a single category.

In Arkansas, the reserves are divided into 5 categories according to the thickness of overburden, in feet, as follows: 0 to 60,60 to 500,500 to $1,000,1,000$ to 2,000 , and 2,000 to 3,000 .

In Michigan, where all the coal is less than 400 feet below the surface, the reserves are divided into 4 categories according to overburden, in feet, as follows: 50 to 100,100 to 200,200 to 300 , and 300 to 400 .

In two States, Montana and North Carolina, calculation of reserves in the 0 - to 1,000 -foot category of overburden was not practicable, and, therefore, a single 0 - to 2,000-foot category was used.

In some States no overburden categories were employed, but in all of these the maximum overburden is 3,000 feet, in several it is less than 2,000 feet, and in a few it is less than 1,000 feet.

The overburden categories used and the maximum overburden considered in each State are discussed in the individual State summaries.

\section{CLASSIFICATION ACCORDING TO RELATIVE ABUNDANCE OF INFORMATION}

Wherever possible, coal reserve estimates reported by the U.S. Geological Survey are divided into three categories according to the relative abundance and reliability of data used in preparing the estimates. These classes are termed "measured," "indicated," and "inferred."

\section{MEASURED RESERVES}

Measured reserves are reserves for which tonnage is computed from dimensions revealed in outcrops, trenches, mine workings, and drill holes. The points of observation and measurement are so closely spaced, and the thickness and extent of the coal are so well defined that the computed tonnage is judged to be accurate within 20 percent or less of the true tonnage. Although the spacing of the points 
of observation necessary to demonstrate continuity of coal varies in different regions according to the character of the coalbeds, the points of observation are, in general, about half a mile apart.

\section{INDICATED RESERVES}

Indicated reserves are reserves for which tonnage is computed partly from specific measurements and partly from projection of visible data for a reasonable distance on geologic evidence. In general, the points of observation are about 1 mile apart, but they may be as much as $1 \frac{1}{2}$ miles apart for beds of known continuity.

\section{INFERRED RESER VES}

Inferred reserves are reserves for which quantitative estimates are based largely on broad knowledge of the geologic character of the bed or region and for which few measurements of bed thickness are available. The estimates are based on an assumed continuity for which there is geologic evidence. In general, inferred coal lies more than 2 miles from the outcrop or from points of mining or drill hole information.

In several States, particularly Montana and Colorado, where the amount of measured reserves is very small, the measured and indicated categories have been combined in a single category. In other States for which only gross, generalized estimates are available, all three categories are combined.

\section{DISTINCTION BETWEEN ORIGINAI, REMAINING, AND RECOVERABLE RESERVES}

Coal reserves may be calculated and presented according to one or all of three different points of view as defined below:

\section{ORIGINAL RESERVES}

Original reserves are reserves in the ground before the beginning of mining operations. In the calculation of original reserves, no allowance is made for past production and losses in mining or for future losses. Most older estimates are for original reserves only.

\section{REMAINING RESER VES}

Remaining reserves are unmined reserves in the ground, as of the date of the estimate, and may be obtained by subtracting past production and losses from original reserves.

\section{RECOVERABLE RESERVES}

Recoverable reserves are reserves in the ground, as of the date of the estimate, that past experience suggests can actually bo produced in the future. Much coal thus classified can be mined at or near 
present costs, measured in man-hours and equipment. The remainder in thinner and less accessible beds can be mined either at gradually increased cost according to the present mining technology, or possibly with little or no increase in cost according to a future, improved mining technology. Recoverable reserves are obtained by subtracting estimated future losses in mining from remaining reserves.

The preparation of an estimate of original reserves aids in the determination of remaining and recoverable reserves because it provides a base figure from which other figures can be derived. An estimate of original reserves, although subject to revision with new mapping and exploration, is essentially a constant, needing no date nor explanation to make it understandable. From this estimate the figures for remaining and recoverable reserves, which must be dated, can be determined annually, if desired, from available information on production and losses or from surveys of mined-out areas.

Coal reserves can be calculated successfully without reference to original reserves where adequate records have been kept of minedout areas, and several modern estimates, particularly those for Alabama, Illinois, Kansas, Maryland and Tennessee, have been made on this basis. However, in most coal areas of the United States, and particularly in the West where little mining has been done, remaining reserves and original reserves are so nearly the same that it is generally preferable to calculate original reserves.

In tables 1 and 2, estimates are presented for original, remaining, and recoverable reserves, as a means of emphasizing the distinctions between these terms. For the five States mentioned above, the estimates presented in the original reserves columns of tables 1 and 2 are for remaining reserves as of the dates the estimates were prepared. These figures have then been reduced by the amount of production plus losses from the dates of the estimates to Jan. 1, 1960, so that all figures in the remaining reserves columns of tables 1 and 2 are comparable.

\section{PERCENTAGE OF COAT RECOVERED IN MINING}

In estimating remaining and recoverable reserves, it is necessary to take into account not only past production, but also both past and estimated future losses in mining. Reasonably accurate figures for past production can be obtained from the annual statistics of production published by the U.S. Bureau of Mines and by various State agencies. The figures for past and estimated future losses in mining are less easily obtained, partly because the percentages of coal recovered and lost in mining differ considerably in different areas and mines, with different operators, and with different methods 
of mining. In localities covered by detailed mine maps, past losses in mining can be determined by comparing production figures with measurements of areas known to be mined out. The necessary detailed maps are not available, however, for many of the coal-mining areas in the United States, and the estimates of individuals familiar with local mining operations provide, in general, the only indication of the relative tonnages of coal that are recovered and lost in mining.

In calculating remaining and recoverable reserves on a regional or national scale, therefore, an average figure for the estimated percentage of recovery in the past and in the future must be derived from a consideration of the relatively few detailed studies available.

\section{UNDERGROUND MINING}

Most studies of recoverability in underground mining involve consideration of individual mines or small areas and typically indicate. a higher recoverability than studies of larger areas. In some individual mines, for example, as much as 80 or 90 percent of the coal in the block actually being mined may be recovered. From the totalresource point of view, however, recoverability seems to be only about 50 percent of the coal in the ground. This marked difference. is due to the fact that studies of recoverability in larger areas include consideration of coal that is left in barrier pillars, in restricted areas around oil and gas wells, under towns, railroads, roads, and streams, in rider beds, and in local areas of complex faulting and folding, as well as the more conspicuous losses in the block or blocks of coal actually being mined.

The results of an investigation by Cady (1949) of the coal resources of Franklin County, Ill., for example, have shown a recovery of less than 50 percent of the coal originally present in the No. 6 bed in that county. A similar study by Flint (1951) has indicated that the recovery of coal in Perry County, Ohio, between 1838 and 1948 was only 43 percent of the amount originally present. In Michigan the recovery of coal has averaged about 60 percent of the total coal in the ground, according to the estimates of individuals familiar with mining operations in the State (Cohee and others, 1950, p. 5). B. W. Dyer has stated (oral communication, 1949) that, in his opinion, mining operations in Utah have not been able to recover more than 50 percent of the total coal in the ground.

Eavenson (1946) has estimated that the actual recovery from the Pittsburgh bed in Pennsylvania is no more than 50 to 60 percent because of the large amount of coal that is left in the barriers, in reservations for oil and gas wells, under buildings, and in the rider above the main bed. In calculating the remaining reserves. of bituminous coal in Pennsylvania, Ashley (1944) assumed a re- 
covery of 50 percent for all coal in the State with the exception of that in the Pittsburgh bed, for which he assumed a recovery: of 66.6 percent. Ashley's figures were based on the percentage recovery of coal in Fayette County, Pa., as determined by Moyer (Hickok and Moyer, 1940).

The weighted averages of recovery in mining bituminous coal in 44 counties in the Appalachian region, as determined by the U.S. Bureau of Mines, ranged from 45.4 to 65.4 percent and averaged about 54 percent (Dowd and others, 1950-56; Wallace and others, 1952-55; Williams and others, 1954-56; Hershey and others, 195556 ; Blaylock and others, 1955-56; Travis and others, 1956; Low $\theta$ and others, 1956; Tavenner and others, 1956).

In Oklahoma, Trumbull (1957, p. 367) has estimated that recoverability in past mining operations has averaged only 39 percent.

As the results of these recently completed studies cluster around 50 percent, the estimated remaining and recoverable reserves of coal shown in tables 1 and 2 are based on the assumption that past mining operations have recovered only 50 percent of the coal in the ground and that this rate will be maintained in the future. Many individual operations recover more than 50 percent of the coal in the ground, however, and it is to be hoped that the general introduction of more efficient mining methods will result in a higher average recoverability in the future.

As production statistics of separate States generally include only the output of the larger mines, the recorded production figures used in tables 1 and 2 are somewhat less than actual production. Thus, the past losses in mining, which are assumed in tables 1 and 2 to be equal to past production, are also somewhat less than actual losses. Therefore, the remaining and recoverable reserves as reported in tables 1 and 2 are somewhat higher than they would be if full and complete data were available for the amounts of coal mined and lost in mining.

A considerable amount of the coal recovered in mining is ultimately lost in the process of mechanical cleaning. In 1958, for example, 63 percent of the bituminous coal and lignite produced was cleaned mechanically, and an average of 19 percent of this amount was discarded as refuse (U.S. Bur. Mines, 1959a, p. 71).

\section{STRIP MINING}

According to Koenig (1950, p. 28) recoverability in strip mining may, under favorable conditions, be as much as 90 percent of the coal originally in the ground. Other operators agree that the average recoverability in strip mining is of the order of 80 percent, and this figure is used preparing many estimates of recoverable. 
strip-mining reserves. Because strippable coal constitutes only a small part of the total reserves and only a modest part of past total production, the use in tables 1 and 2 of the 50-percent recoverability factor for all coal seems to be justified.

\section{DISTRIBUTION OF RESERVES IN SELECTED CATEGORIES}

Coal-bearing rocks underlie about 13 percent of the surface area of the United States, including Alaska and Hawaii, and about 14 percent of conterminous United States. (See table 4, fig. 1; Trumbull, 1960, Barnes, 1961.) These rocks are present in 37 States, including a few, such as Mississippi, New York, and Nevada, in which the coal-bearing areas are small or the reserves insignificant, and others, such as Illinois and West Virginia, in which coal-bearing areas represent more than half the total area of the State. The wide distribution of accessible coal has contributed greatly to the industrial growth of the United States.

The distribution of reserves on a tonnage basis is roughly proportional to the distribution of coal-bearing rocks, although in a few large areas of coal-bearing rocks, such as those in Michigan and Texas, the reserves are relatively small, and in other areas, such as some in the Rocky Mountain region, the coal-bearing rocks are deeply buried, and the contained coal is not included in current estimated reserves.

\section{DISTRIBUTION ACCORDING TO RANK}

The large tonnage of coal in the United States is distributed quite unequally among five categories of rank. As determined from the totals in tables 1 and 2, about 47 percent of the original reserves in the United States is bituminous coal, including 1.1 percent of low-volatile bituminous coal. By comparison, 25.5 percent is subbituminous coal, 26 percent is lignite, and only 1.5 percent is anthracite. This percentage distribution is presented graphically on figure 5A: It should be noted that the comparisons shown on figure 5 are based on tons. A comparison based on the contained heat value would show longer columns for bituminous coal and progressively shorter columns for subbituminous coal and lignite.

The geographic distribution of reserves of the different ranks is also unequal. About 60 percent of the reserves of the higher rank bituminous coal and anthracite is found east of the Mississippi River, although this part of the United States contains only 40 percent of the total estimated reserves. West of the Mississippi River, reserves of the higher ranks of coal are present only in comparatively small quantities in Arkansas, Oklahoma, Colorado, and 
TABLE 4.-Size and percentage distribution of coal-bearing areas in the United States

\begin{tabular}{|c|c|c|c|}
\hline \multirow{2}{*}{ State } & \multirow{2}{*}{$\begin{array}{l}\text { Total area of } \\
\text { State 1 (square } \\
\text { miles) }\end{array}$} & \multicolumn{2}{|c|}{$\begin{array}{l}\text { Area underlain by } \\
\text { coal-bearing rocks }\end{array}$} \\
\hline & & (Square miles) & (Percent) \\
\hline 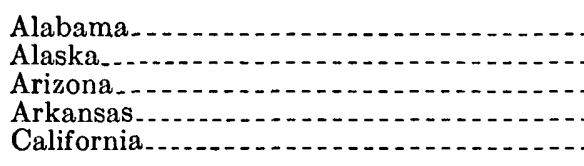 & $\begin{array}{r}51,609 \\
586,400 \\
113,909 \\
53,104 \\
158,693\end{array}$ & $\begin{array}{r}9,700 \\
35,000 \\
3,040 \\
1,700 \\
230\end{array}$ & $\begin{array}{r}19 \\
6 \\
3 \\
3 \\
.\end{array}$ \\
\hline $\begin{array}{l}\text { Colorado } \\
\text { Georgia } \\
\text { Idaho } \\
\text { Illinois } \\
\text { Indiana...... }\end{array}$ & $\begin{array}{r}104,247 \\
58,876 \\
83,557 \\
56,400 \\
36,291\end{array}$ & $\begin{array}{r}29,600 \\
170 \\
500 \\
37,700 \\
6,500\end{array}$ & $\begin{array}{l}28 \\
67^{6} \\
18\end{array}$ \\
\hline 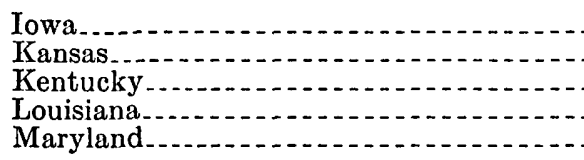 & $\begin{array}{l}56,290 \\
82,276 \\
40,395 \\
48,523 \\
10,577\end{array}$ & $\begin{array}{r}23,100 \\
18,800 \\
14,600 \\
1,360 \\
440\end{array}$ & $\begin{array}{r}41 \\
23 \\
36 \\
3 \\
4\end{array}$ \\
\hline $\begin{array}{l}\text { Michigan } \\
\text { Mississippi... } \\
\text { Missouri } \\
\text { Montana } \\
\text { Nebraska }\end{array}$ & $\begin{array}{r}58,216 \\
47,716 \\
69,674 \\
147,138 \\
77,227\end{array}$ & $\begin{array}{r}11,600 \\
1,000 \\
24,700 \\
51,300 \\
300\end{array}$ & $\begin{array}{r}20 \\
2 \\
35 \\
35 \\
.4\end{array}$ \\
\hline $\begin{array}{l}\text { Nevada } \\
\text { New Mexico } \\
\text { New York } \\
\text { North Carolina. } \\
\text { North Dakota... }\end{array}$ & $\begin{array}{r}110,540 \\
121,666 \\
49,576 \\
52,712 \\
70,665\end{array}$ & $\begin{array}{r}50 \\
14,650 \\
10 \\
155 \\
32,000\end{array}$ & $45^{3}$ \\
\hline $\begin{array}{l}\text { Ohio } \\
\text { Oklahoma } \\
\text { Oregon } \\
\text { Pennsylvania } \\
\text { South Dakota. }\end{array}$ & $\begin{array}{l}41,222 \\
69,919 \\
96,981 \\
45,333 \\
77,047\end{array}$ & $\begin{array}{r}12,350 \\
14,550 \\
600 \\
15,000 \\
7,700\end{array}$ & $\begin{array}{l}25 \\
21 \\
33^{6} \\
10\end{array}$ \\
\hline $\begin{array}{l}\text { Tennessee } \\
\text { Texas } \\
\text { Utah } \\
\text { Virginiang } \\
\text { Washington. }\end{array}$ & $\begin{array}{r}42,244 \\
267,339 \\
84,916 \\
40,815 \\
68,192\end{array}$ & $\begin{array}{r}4,600 \\
16,100 \\
15,000 \\
1,940 \\
1,150\end{array}$ & $\begin{array}{r}11 \\
6 \\
18 \\
5 \\
2\end{array}$ \\
\hline $\begin{array}{l}\text { West Virginia } \\
\text { Wyoming } \\
\text { Other States including Hawaii... }\end{array}$ & $\begin{array}{r}24,181 \\
97,914 \\
312,830\end{array}$ & $\begin{array}{r}16,800 \\
40,055 \\
0\end{array}$ & $\begin{array}{r}69 \\
41 \\
0\end{array}$ \\
\hline United States total_ & $3,615,210$ & 464,050 & 13 \\
\hline
\end{tabular}

1 U.S. Bureau of the Census, 1958, Statistical abstract of the United States; 79th ed., p. 160.

Washington. The 60 percent of the United States reserves west of the Mississippi River is mostly lignite, subbituminous coal, or highvolatile $\mathrm{C}$ bituminous coal.

The reserves of lignite and subbituminous coal in the West have only local value at present, though it is certain that they will have 

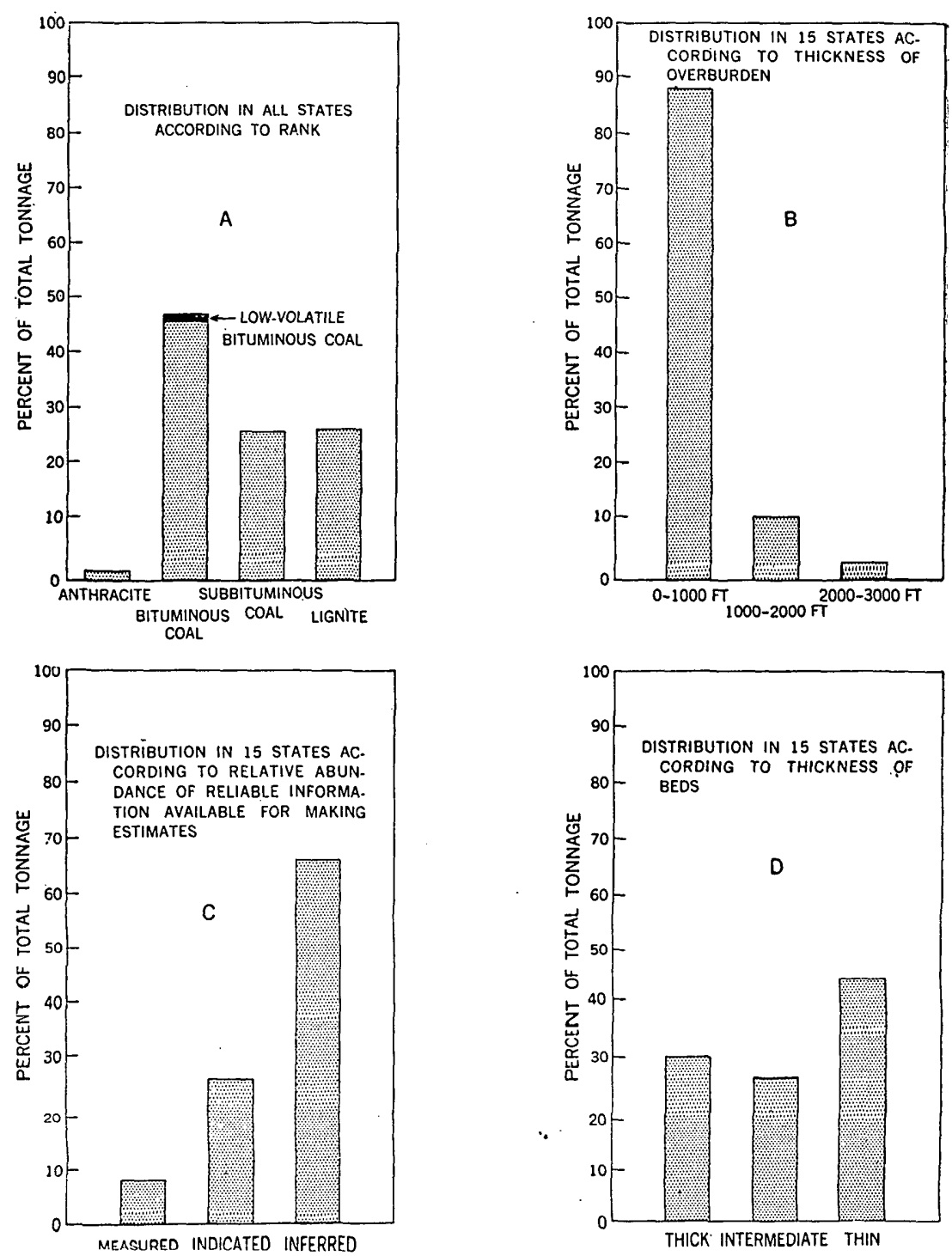

Fioure 5.-Percentage distribution of estimated original coal reserves $(A)$ in all States according to rank; and in 15 States, according to $(B)$ thickness of overburden, (C) relative abundance of reliable information arallable for making estimates, and (D) thickness of beds.

greater usefulness in the future. Coals of these ranks tend to crumble during transportation and to ignite by spontaneous combustion if stored for too long a period without special precautions. They also have lower heat value than other coals. On the other hand, the low-rank coals are well suited for the production of electric power and the production of synthetic gas and liquid fuels, and in 
many parts of the West they can be mined efficiently by stripping methods.

The geographic distribution of the different ranks of coal is related principally to differences in geologic age. Nearly all the coal in States east of the Mississippi River anr in Iowa, Kansas, Missouri, Oklahoma, and Arkansas is of Pennsylvanian age; in the Western States, on the other hand, nearly all the coal is of much younger, Cretaceous or Tertiary age. The younger western coal attains high rank only where it has been deformed and altered by the forces that accompanied mountain building and by the intrusion of igneous rock.

\section{DISTRIBUTION ACCORDING TO RESERVE CATEGORIES OTHER THAN RANK}

Figures $5 B, 5 C, 5 D$, and figure 6 show the percentage distribution of estimated original reserves in categories other than rank in 15 States, which contain about half of the total estimated reserves in the United States. These 15 States, Alabama, Arkansas, Colorado, eastern Kentucky, Illinois, Indiana, Michigan, Montana, New Mexico, North Carolina, North Dakota, Oklahoma, South Dakota, Virginia, and Wyoming, are those in which reserve information is classified in sufficient detail to permit statistical conclusions about the distribution of reserves in the additional categories. The sample presented by the 15 States is fairly large, however, and the observed distribution should show the general order of magnitude of distribution for the United States as a whole.

\section{DISTRIBUTION ACCORDING TO THICKNESS OF OVERBURDEN}

Figure $5 B$ shows the percentage distribution of original reserves in 3 categories according to thickness, in feet, of overburden: 0 to $1,000,1,000$ to 2,000 , and 2,000 to 3,000 . It is noteworthy that 88 percent of the estimated reserves in the 15 States is less than 1,000 feet below the surface, and that only 10 percent and 2 percent, respectively, are present in the 1,000- to 2,000-foot and 2,000- to 3,000foot categories. The impressive concentration of reserves in the 0 to 1,000-foot category is due in part to the fact that coal-bearing rocks lie near the surface in many places and in part to the fact that less information is available for the more deeply buried beds. Most of the coal mined in the United States today, for example, is taken from beds less than 1,000 feet below the surface, and only a small amount is mined from beds 1,000 to 2,000 feet below the surface. In the United States no significant amount of coal is mined from beds more than 2,000 feet below the surface, though. in Belgium mining has been carried to a depth of nearly 4,000 feet. 


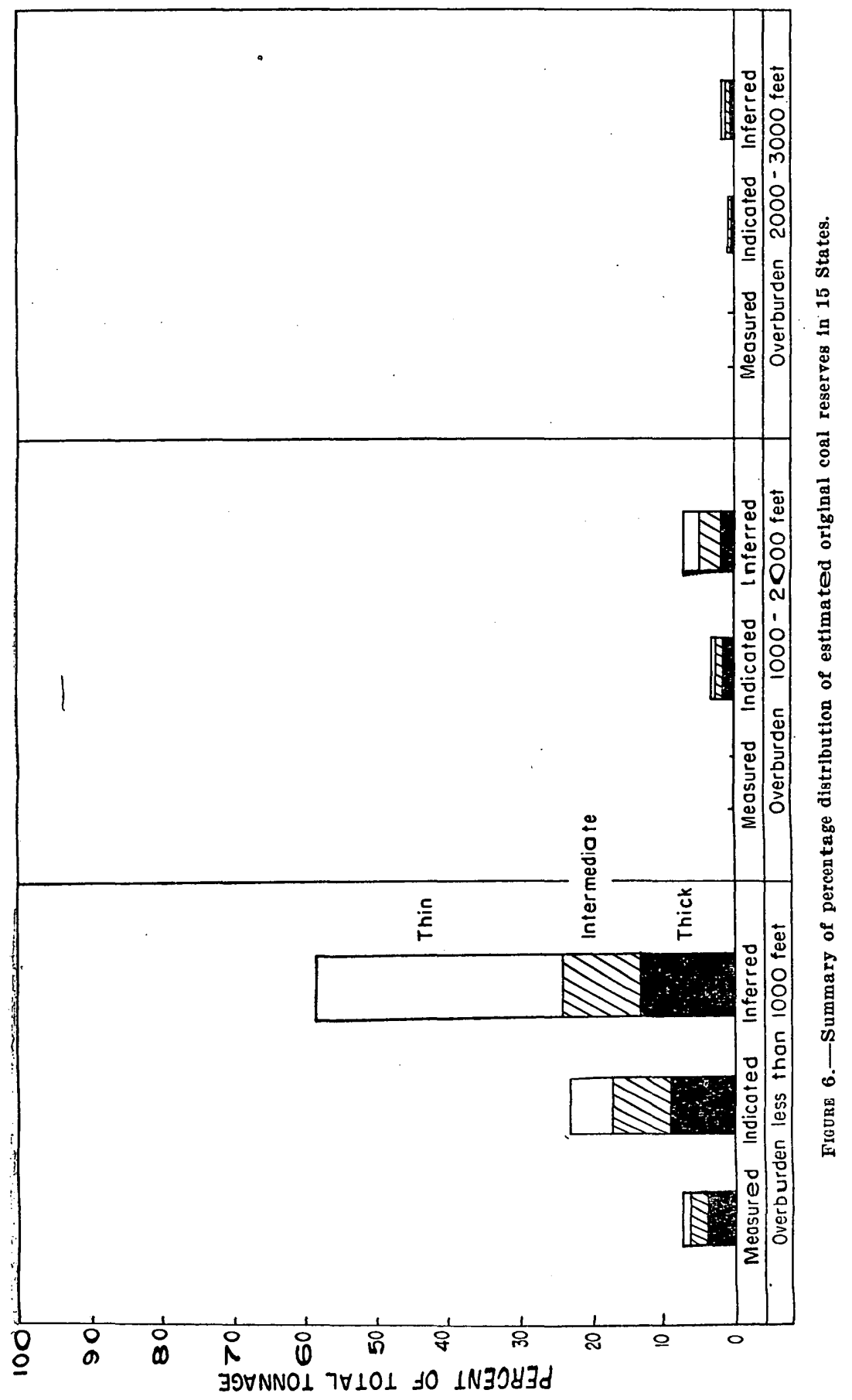


As exploration and development are carried to greater depths, it is certain that the total estimated reserves in the United States will be considerably increased by the addition of reserves in the deeper overburden categories.

\section{DISTRIBUTION ACCORDING TO RELATIVE ABUNDANCE AND RELIABILITY OF INFORMATION}

Figure $5 C$ shows the percentage distribution of original reserves in the measured, indicated, and inferred categories, as previously defined. Of the large tonnage of classified reserves in the 15 States, 8 percent is classed as measured, 26 percent as indicated, and 66 percent as inferred. The larger figure for inferred reserves of course reflects the lack of precise data for many of the coal-bearing areas. It is, however, a convenient method of expressing the amount of coal that can be inferred with confidence to be present on the basis of current geologic information. Additional geologic mapping and exploration in any of the coal-bearing areas included in this distribution study would undoubtedly serve to increase the tonnage of measured and indicated reserves and might also increase the tonnage of inferred reserves.

\section{DISTRIBUTION ACCORDING TO THICKNESS OF COAL}

The terms "thick," "intermediate," and "thin," as used in figure $5 D$, refer to beds of coal in three thickness categories, which differ for the different ranks of coal. Included as "thick" are bituminous coal and anthracite more than 42 inches thick and subbituminous coal and lignite more than 10 feet thick. Included as "intermediate" are anthracite and bituminous coal 28 to 42 inches thick and subbituminous coal and lignite 5 to 10 feet thick. Included as "thin" are anthracite and bituminous coal 14 to 28 inches thick and subbituminous coal and lignite $21 / 2$ to 5 feet thick.

As recorded in the diagram, coal in thick beds makes up 30 percent of the total, coal in beds of intermediate thickness makes up 26 percent, and coal in thin beds makes up 44 percent. The relatively low percentage of reserves in beds of intermediate thickness is probably due in part to a human tendency to assign minimum thicknesses to beds in the inferred category and thus increase the amount of coal in the thin category.

\section{DISTRIBUTION IN ALL CATEGORIES}

Figure 6 summarizes the distribution of reserves in the three major categories presented in figures $5 B, 5 C$, and $5 D$. The figure clearly shows the preponderance of reserves in the 0 - to 1,000 -foot category and the relatively small quantities of measured reserves in all categories. Reserves are present in each of the 27 possible cate- 
gories allowed for in figure 6, except the one representing measured reserves in thin beds 2,000 to 3,000 feet below the surface. The amounts in several categories are less than 1 percent of the total and could not be shown on a diagram of this scale.

Like figures $5 B, 5 C$, and $5 D$, figure 6 also shows the conservative character of the estimates for the reserves in the 15 selected States. The relatively large percentages of reserves in the indicated and inferred categories and the small percentages in the measured category are due to a lack of data-not a lack of coal. The relatively small percentage of coal in the 1,000- to 2,000-foot category as compared to the 0 - to 1,000 -foot category is also due primarily to lack of data; the deeper overburden categories contain much larger reserves than the estimates show.

\section{COKING-COAL RESERVES}

Coke is usually manufactured from blends of two or more coals of different composition and may incorporate small amounts of other ingredients such as anthracite fines, petroleum coke, or low-temperature char. In spite of the common use of the term "coking coal," very little coal can be used alone to produce coke suitable for metallurgical processes. When a single coal is used, it is of mediumvolatile bituminous rank and reasonably free of ash and sulfur. Reserves of such coal are small and are rapidly being depleted. The desired properties are more readily obtained by blending two or more coals of different rank and composition. Generally, 15 to 30 percent of low-volatile bituminous coal, which is very strongly coking, is blended with 85 to 70 percent of high-volatile bituminous coal, which is weakly coking. In 1957 , high-volatile bituminous coal constituted 66 percent of the total coal made into coke, whereas medium-volatile constituted 11 percent, and low-volatile 23 percent (U.S. Bur. Mines, 1959b, p. 213). The nature of the original plant constituents also is a factor in determining coking properties, as are the deleterious constituents, ash and sulfur. With these several variables to be taken into account, modern coking-coal blends have become complex mixtures of carbonaceous material.

Most reserves of high-rank and high-quality coal best suited for the production of coke and coal chemicals are in the East, principally in West Virginia, Pennsylvania, Kentucky, and Virginia.

In a few areas in the West, principally in Colorado, Utah, Oklahoma, Arkansas, Washington, and New Mexico, coal is produced that is satisfactory for the manufacture of coke when used in blends. The most important areas in the West are the Raton Mesa region, Colorado-New Mexico; the Sunnyside field, Utah; and the Somerset-Crested Butte-Carbondale region, Colorado. These areas 
stand out prominently in plans for the industrial development of the West. Summary information about reserves of coking coal in the West is contained in reports by Berryhill and Averitt (1951), Landis (1959), and Trumbull (1957).

Because of the almost limitless possibilities of blending coals and hydrocarbons in the manufacture of coke, and because of the certainty that the acceptable amounts of impurities in coke will be allowed to increase and coking properties to decrease as the higher rank and higher grade coals are depleted, it is impossible to define coking coal in precise terms.

It is possible, however, to consider separately the reserves of lowvolatile bituminous coal, which is the important blending component that permits use of the vastly larger quantities of high-volatile bituminous coal. As shown in the accompanying table, the estimated reserves of low-volatile bituminous coal are contained largely in 6 States, and represent only 1.1 percent of total United States reserves calculated on a simple tonnage basis.

Relation of original reserves of low-volatile bituminous coal to original reserves of coal of all ranks in the United States

[In millions of short tons]

\begin{tabular}{|c|c|c|c|}
\hline State & $\begin{array}{l}\text { Reserves of low- } \\
\text { volatile bitumi- } \\
\text { nous coal }\end{array}$ & $\begin{array}{l}\text { Total coal } \\
\text { reserves }\end{array}$ & $\begin{array}{l}\text { Percent of total } \\
\text { coal reserves }\end{array}$ \\
\hline $\begin{array}{l}\text { Pennsylvania } \\
\text { West Virginia. } \\
\text { Maryland 1. } \\
\text { Virginia. } \\
\text { Arkansas. } \\
\text { Oklahoma } \\
\text { Other States. }\end{array}$ & $\begin{array}{r}5,673 \\
10,251 \\
700 \\
300 \\
1,816 \\
747 \\
50\end{array}$ & $\begin{array}{r}97,898 \\
116,618 \\
1,200 \\
12,051 \\
2,622 \\
3,673 \\
1,485,902\end{array}$ & $\begin{array}{r}5.8 \\
8.8 \\
58.3 \\
2.5 \\
69.2 \\
20.3 \\
\end{array}$ \\
\hline United States total & 19,537 & $1,719,964$ & 1. 1 \\
\hline
\end{tabular}

1 Remaining reserves, Jan. 1, 1950.

The State estimates shown in the table may be changed in time as new information is obtained and as progress in estimating reserves is continued. Nevertheless, the ratio of original low-volatile bituminous coal reserves to total original reserves can be expected to remain about the same, because any change in the tonnage figure for low-volatile reserves will probably be accompanied by a change in the figure for total reserves. Therefore, the most significant figures in the table are the percentage figures, particularly the overall figure of about 1 percent, which is certainly not subject to any significant future change.

Mining has been carried on extensively in the areas containing low-volatile bituminous coal because of its many desirable qualities. 
As a semismokeless fuel with a high heat value, it is in great demand for many purposes other than the production of coke. In 1947, for example, only 25 percent of the low-volatile bituminous coal produced was used in the manufacture of coke. In that year the total output of low-volatile bituminous coal was 84 million tons, or about 12 percent of the total coal production (Fieldner, 1950, p. 13-14).

In many areas of less desirable and less readily accessible coal in the United States, the remaining reserves are very nearly equal to the original reserves because little mining has been done. The areas containing low-volatile bituminous coal, on the other hand, are rapidly being mined out, and the remaining reservès of this coal are now much less than 1 percent of the total coal remaining in the United States, of which no more than half can be regarded as recoverable. With only a limited supply of low-volatile bituminous coal available, it is apparent that coking operations and metallurgical processes soon must be adjusted to permit increasing use of lower rank coal.

\section{STRIPPING-COAL RESERVES}

The continuous increase in strip mining that has taken place since World War I has been brought about by the substantially lower operating costs of strip mining, due primarily to improvement in earth-moving machinery. In 1920, strip mining accounted for only 1.5 percent of the total coal mined in the United States, whereas by 1958 strip mining accounted for 28.3 percent. In 1920 there were 312 power shovels and draglines in operation, whereas by 1958 there were 3,515 (U.S. Bur. Mines, 1959a, p. 43). The largest electric shovel operating in 1959 was capable of removing as much as 70 cubic yards, or 105 tons, of earth at a single bite-a capacity many times that of the small steam shovels of only a few years ago.

Because of the newer, more efficient strip mining machinery, the ratio of overburden thickness to coal thickness that can be handled profitably has steadily increased, and many beds previously considered inaccessible for strip mining are now readily accessible. For overburden not exceeding 60 feet, ratios of overburden thickness to coal thickness as much as 20 to 1 are entirely practicable, though much depends on the density and hardness of the overburden, rank and quality of the coal, distance to transportation facilities and market, and other purely economic factors. For overburden exceeding 60 feet, somewhat smaller ratios are practicable, although the ratios decrease markedly with increase in thickness of overburden above 60 feet, which represents the lifting capacity of most existing shovels. 
The maximum thickness of overburden that can be removed economically is also increasing steadily as the very large shovels with increased lift and swing come into use. In 1955, the maximum overburden handled in mining bituminous coal and lignite was about 70 feet (U.S. Bur. Mines, 1959b, p. 70), whereas by 1959 the maximum was about 100 feet. Anticipating the trend toward stripping to greater depths, the Illinois Geological Survey in outlining areas suitable for strip mining has presented data on overburden to a maximum of 150 feet.

Some of the more spectacular coal mining operations are those in which the coal is being recovered by stripping methods. The thickest bed now being mined by stripping in the United States is at Wyodak, Wyo., where the coal is 90 feet thick. The deepest strip pits in the United States are in the Pennsylvania anthracite fields, where an overburden of about 120 feet is being removed. A feature of the mining in this area is that the outcrops are now being worked for the third time. The first time was by underground mining, which recovered only a small percentage of the coal near the outcrops. The second time was by stripping along the outcrop with small shovels. The third time is by stripping the partly minedout zone just below the older stripped zone with large draglines and shovels.

In 1958, Ohio was the leading State in strip-coal production, followed in order by Illinois, Pennsylvania, Kentucky, Indiana, and West Virginia.

The total stripping-coal reserves in the United States have not been estimated. Although the amount must be considerable, as demonstrated by the size of the industry, it must inevitably be only a small part of total reserves because of the ultimate practicable limit to the amount of overburden that can be removed. The amount of strippable coal in the East, where most strip mining is carried on, is certainly less than the amount in the northern Great Plains province, particularly in North Dakota, Montana, and Wyoming, where the reserves are very large.

The reserves of strippable coal have been calculated for Kansas, Indiana, and part of Illinois. The proved strippable reserves in Kansas, as of 1947 , totaled 60 million tons, based on an assumed weight of 1,500 tons per acre-foot (Abernathy and others, 1947). This figure represents 0.3 percent of the total estimated original coal reserves in the State.

In Indiana, the strippable coal reserves, as of 1950, totaled 3,524 million tons, based on an assumed weight of 1,800 tons per acre-foot (Spencer, 1953). This tonnage is 9.4 percent of the total estimated original coal reserves in the State. 
In 1957 and 1958 the Illinois Geological Survey published two reports describing stripping-coal reserves in 11 counties in the southern part of the Illinois basin (Smith, W. H., 1957, 1958). In these counties the original strippable reserves, including beds to a maximum depth of 150 feet, total 4,643 million tons, which is about 25 percent of the total reserves. This high ratio obviously applies only to coal on the edges of the coal basin and not to the more deeply buried coal in the interior.

The U.S. Geological Survey has published five reports on a number of selected areas favorable for large-scale strip mining in Montana and North Dakota but the reserves included in these reports represent only a small part of the total strippable coal available (Brown and others, 1954; Culbertson, 1954; Kepferle, 1954; Kepferle and Culbertson, 1955; May, 1954).

The use of stripping methods in mining greatly increases the total amount of coal that is ultimately recoverable, for strip mining recovers an average of about 80 percent of the total coal in the ground. Strip mining also adds to the total recoverable coal reserves by making possible the mining of coal under shallow overburden, in badly faulted areas, or in small isolated pockets, where underground mining would not be practicable.

In some individual operations, when stripping has been extended as far as is justified for reasons of economy and safety, additional coal is recovered by the use of a horizontal auger which bores into the coalbed at the base of the highwall. A large-size coal auger has a diameter of 60 inches and penetrates a maximum of 200 feet into the bank. This method permits a theoretical recovery of 75 percent of the coal in a block of ground being mined. In 1958, about 7.3 million tons, or 1.8 percent of the total bituminous coal produced, was mined by augers (U.S. Bur. Mines, 1959a, p. 43).

Recently, mining at the outcrop of the coalbed has been further extended by the use of a continuous mining system in which a machine equipped with four overlapping cutting heads produces a hole about 10 feet wide and 3 feet high. The full height of the coalbed can be recovered by means of successive cuts. Currently, the depth of the hole is limited to 1,000 feet, the length of the cable supplying power. The thickness of the pillar left between borings depends upon roof conditions, but, in general, recovery of coal by means of this continuous mining system is approximately 65 percent.

\section{PRODUCTION OF COAL IN THE UNITED STATES}

The United States produces about 20 percent of the coal mined annually throughout the world. By way of comparison, the U.S.S.R., 


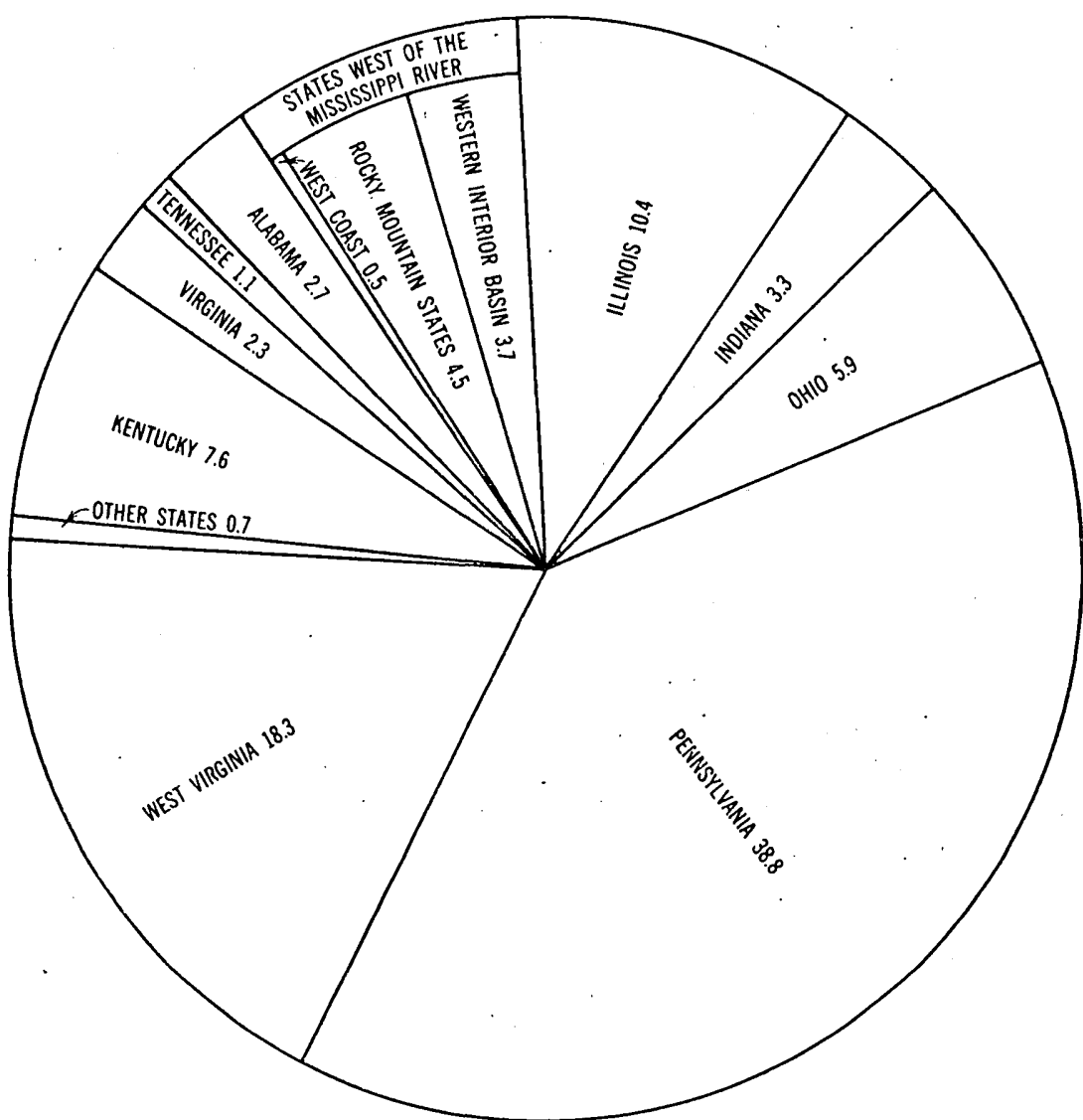

Figure 7.-Distribution of cumulated coal production in conterminous United States to Jan. 1, 1960.

excluding satellite countries, also produces about 20 percent, and the rest of Europe produces about 45 percent. $^{3}$

The cumulative production of coal in the United States to January 1,1960 , totals about 34,800 million tons, which is equivalent to a solid cube of coal 1.8 miles on a side. Half this total has been mined since 1926 .

The accompanying diagram (fig. 7) shows the distribution by States of cumulative production in conterminous United States to January 1, 1960. Most conspicuous on the diagram is the preponderance of production from West Virginia and Pennsylvania and the fact that more than 90 percent of production has come from coal fields east of the Mississippi River.

Before the Revolutionary War, coal was mined only in a very small way by the American colonists and was used mostly in black-

3 All statistical data in this section taken from U.S. Bureau of Mines Minerals Yearbooks for 1957 and prior years. 
:smith forges. In the early 1800 's, production began to increase rapidly and more than doubled during some decades in the first half of the century. Production continued to double every 10 years or so until about the time of World War I. An early peak in coal production was reached in 1918 when 678 million tons was mined. Following World War I, coal production fluctuated below the 1918 peak, due in part to the great expansion in use of petroleum and natural gas, which began in the 1920's and has continued until the present time, and in part to the business depression of the 1930's. World War II brought about an increase in coal production, and a second, alltime peak of 688 million tons was reached in 1947. Following 1947, coal production tapered off, and in the 10-year period from 1950 to 1959 the annual production ranged from 427 to 524 million tons and averaged about 484 million tons. This average amount would fill 20 continuous lines of coal cars extending from New York to San Francisco. ${ }^{4}$

The mining and distribution of coal is the second largest mineral industry in the United States. The coal produced in 1957, an average recent year, had an estimated value_of $\$ 2,736$ million. This is more than the value of any other mineral or fuel commodity except petroleum and is more than that of all metallic minerals combined.

In 1957 there were 8,539 operating bituminous coal and lignite mines in the United States, ranging in size from small mines producing as little as 1,000 tons per year to the largest mines producing more than 500,000 tons a year. Almost half of the 1957 production was obtained from 245 mines of the largest class.

Most of the coal mined in the United States is obtained from moderately thick beds. According to a study of 1955 production from bituminous coal and lignite mines by Young and Anderson (1957), 40 percent of 1955 production was obtained from beds 4 to 6 feet thick, and smaller quantities were obtained from beds in other thickness categories, as shown in the following tabulation:

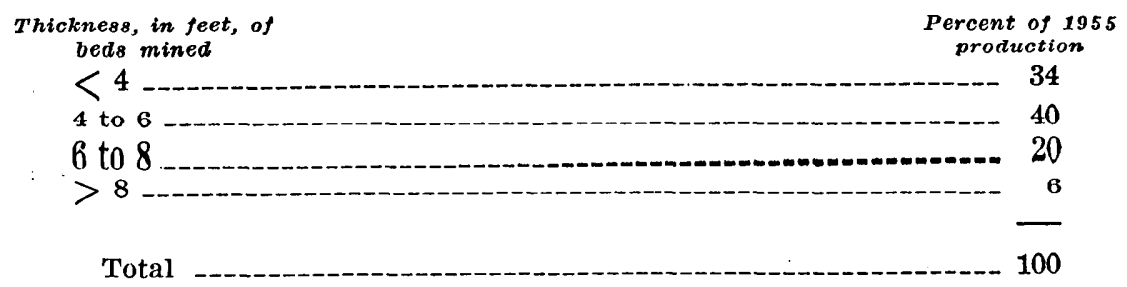

Coal-mining methods have changed greatly through the years. In 1920, for example, less than 1 percent of bituminous coal and

\footnotetext{
${ }^{4}$ Assuming that a line of loaded coal cars 1 mile long holds 7,500 tons.
} 
lignite production by underground methods was mechanically loaded, whereas by 1958 a record 85 percent was mechanically loaded. In 1920 strip mining accounted for only 1.5 percent of the coal produced, whereas by 1958 strip mining accounted for 28.3 percent of the coal produced.

\section{USES OF COAL}

In addition to serving as an economical source of heat and energy, coal is a highly versatile chemical raw material and is the source or the main component of hundreds of chemical products.

As shown in the following table, the fast-growing electric utility industry is now the largest single user of coal, followed in order by the steel and manufacturing industries:

Consumers of bituminous coal and lignite in 1957

[U.S. Bureau of Mines Minerals Yearbook, 1957, p. 120-122.]

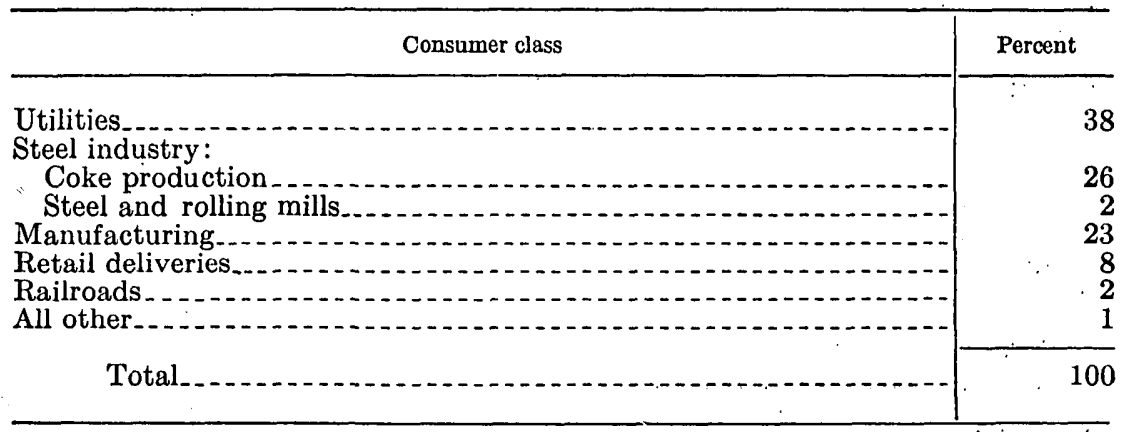

The growth of the utilities is being impelled steadily upward by the growth in population, the increased use of electric appliances, particularly air conditioning, and by the growth of the aluminum and uranium industries.

The steel industry has always been an important and steadily growing customer for coal. Most of the annual coke production, which is recorded separately in the table, is used by the steel industry, for about 1 ton of coke is needed to produce 1 ton of steel. Most of the coke is manufactured in byproduct ovens, which also yield the basic coal chemicals-coal gas, sulfate of ammonia, light oils, and tar-from which are derived a myriad of other chemicals and products, including explosives, paints, dyes, fertilizers, plastics, nylon, and drugs.

The manufacturing industries, which constitute the third most important consumer class, use coal largely as a source of heat and power.

Very little coal is now consumed for household heating bècause 
of the increased use of oil and natural gas for this purpose. Such coal as is used for household heating is included under the heading of "Retail deliveries," which accounted for 8 percent of 1957 consumption.

Railroads, the largest single users of coal up to the end of World War II, have turned almost completely to diesel locomotives and in 1957 accounted for only 2 percent of coal consumption. Much of the coal consumed by railroads in 1957 was used in powerhouses and shops.

Coal has several minor uses that are not recorded in the table. Lignite mined in Amador County, Calif., is an important source of montan wax (Jennings, 1957, p. 158), and bituminous coal mined in Carbon County, Utah, is a source of resins.

In North Dakota, weathered lignite, locally known as leonardite, has been processed to manufacture brown wood stains and also to form a stabilizing agent for mud used in oil and gas drilling (Brant, 1953, p. 58). In Arkansas, lignite has been used to manufacture the dye "Vandyke brown."

Ash from utility plants is used in the manufacture of concrete and cinder blocks, and crushed coal is being studied experimentally for use in road construction.

Some Pennsylvania anthracite of very uniform density has been shaped and polished to form jetlike ornamental objects.

Coal also contains several minor elements of great interest and potential economic importance, which are discussed under a separate heading below.

\section{MINOR ELEMENTS IN COAL}

Coal contains small quantities of essentially all metallic and nonmetallic elements, which were introduced in one or all of four different ways:

1. As inert material washed into the coal swamp at the time of plant accumulation.

2. As a chemical precipitate from the swamp water.

3. As a minor constituent of the original plant cells.

4. As a later addition, introduced after coal formation primarily by downward and laterally moving ground water.

When coal is burned, most of these elements are concentrated in the coal ash. Analyses of coal ash show that it is composed largely of the oxides of silicon, aluminum, iron, calcium, magnesium, potassium, sodium, and sulfur, which typically make up 93 to 98 percent of the total weight of ash (Selvig and Gibson, 1956). Sulfur is present in coal in several forms and in total amount generally 
ranges from less than 1 to a maximum of about 8 percent. When coal is burned, the sulfur is partly dissipated as sulfur dioxide $\left(\mathrm{SO}_{2}\right)$ and is only partly retained in the coal ash. As the quantity of sulfur reported in ash is less than the total in coal, and as sulfur is a well-known constituent of coal, it will not be considered further in this short discussion of minor elements. The remaining fow percent of coal ash is made up of about 25 different minor elements, the concentration of which differs greatly in different areas and beds.

Most of these minor elements occur in coal in about the same concentration as in the earth's crust, but a few, notably uranium, molybdenum, arsenic, boron, and germanium, occur locally in vastly greater concentrations, and a few others, including barium, strontium, and lead, occur in significantly greater concentrations (Francis, 1954, p. 98; Krauskopf, 1955, p. 418; Mason, 1958, p. 44). Several noteworthy minor elements in coal are discussed in the following paragraphs.

\section{URANTUM}

Uranium occurs locally in coal as compounds or complexes intimately associated with the organic constituents. In a few localities the uranium content is high enough to suggest the possibility of mining the coal as uranium ore. As a result, a large amount of study has been directed toward such coals (Kehn, 1957; and Page and others, 1956 , p. 405-444, particularly bibliographies, p. 410, 418, 430, $438,444)$.

Some beds of lignite and carbonaceous shale in southwestern North Dakota and northwestern South Dakota contain an average of 0.18 percent uranium, 0.3 percent molybdenum, 0.09 percent phosphorus, and 0.01 percent vanadium. These figures apply to the full thickness of the carbonaceous beds, which contain an average of about 45 percent ash. These rocks also contain anomalously high amounts of arsenic, germanium, selenium, cobalt, and zirconium.

Carbonaceous material has a strong chemical affinity for uranium, and uranium in solution is readily absorbed or precipitated by contact with lignite or carbonaceous shale. It is generally believed that the uranium and associated elements in the Dakota lignite deposits were leached by ground water from overlying tuffaceous rocks and carried downward and precipitated on and in the underlying lignite. (Denson and Gill, 1956; Denson and others, 1959).

\section{GERMANIUMI}

In the United States, germanium is produced primarily as a byproduct of zinc smelting. The expanded use of germanium in crystal diodes and transistors in the period following World War II 
greatly stimulated interest in coal as a secondary source of this element, and, as a result, much new information was obtained (Stadnichenko and others, 1953; Headlee and Hunter, 1951; Schleicher and Hambleton, 1954).

Germanium is concentrated locally in the top and bottom layers, or just above a thick parting in a coal bed, and is much more abundant in the bright (vitrain) bands than in the dull bands.

The highest concentration of germanium in the United States discovered to date has been in coalified logs and pieces of woody coal in sediments of Cretaceous age in the Atlantic Coastal Plain. Some of these logs contain as much as 7.5 percent germanium in the ash. The commercial coal richest in germanium is the Lower Kittanning bed in eastern Ohio. In this bed the germanium is concentrated in the lower layer. Samples of this layer contain 0.2 percent germanium in the ash, and the ash ranges from 3.54 to 6.86 percent (Stadnichenko and others, 1953, p. 1,9).

\section{BARIUM AND STRONTIUM}

Barium and strontium both show significant, but not large, concentrations in the ash of some coals. Analyses of the ash of 35 samples of coal, as reported by Deul and Annell (1956, p. 163), showed averages of 0.54 percent $\mathrm{SrO}$ and 0.31 percent $\mathrm{BaO}$.

The barium and strontium seem to be, in large part, remaining constituents of the original plant cells and, in small part, the result of enrichment by circulating ground water.

\section{BORON}

The concentration of boron in certain coals is also much higher than the apparent concentration of boron in the earth's crust. Analyses of the ash of 319 samples of low-rank coal from Texas, Colorado, North Dakota and. South Dakota showed an average of about 0.1 percent boron, and individual beds elsewhere have been reported to contain as much as 2 percent boron in the ash (Deul and Annell, 1956, p. 163-164).

Boron is a minor constituent of living plants, and at least some of the boron in coal was derived from the original plant constituents.

\section{OWNERSHIP OF COAL LANDS}

The coal lands of the United States are held largely by several broad classes of owners, including the Federal and State Governments, mining and manufacturing corporations, railroads, Indian tribes, and private individuals. Information about the ownership 
of the surface, coal, and mineral rights for any individual tract of land can be ascertained fairly readily from the records of appropriate county, State, or Federal agencies. However, no study of the overall distribution of ownership has been made to date because of the size and complexity of the task.

Most of the coal lands in the East and in the Mississippi Valley region are privately owned. In the Appalachian Basin, many large tracts of coal land are held by mining, manufacturing, or landholding corporations. In this area also the three or four main eastern coal-hauling railroads own some coal lands along their right-of-ways. In areas remote from transportation facilities, some coal acreage is owned by individual counties, having been acquired through failure of the owners to keep up real estate tax payments. A few small tracts in State Parks and Forests and elsewhere are held by the Federal Government, but, in general, such federally owned coal lands constitute only a very small part of the total in the East.

Most of the coal lands in the Rocky Mountain and northern Great Plains regions are owned by the U.S. Government. In disposing of lands in the public domain according to public land laws before 1920, the Federal Government appraised each tract of land for its coal value and fixed the sales price accordingly. Following passage of the Mineral Leasing Act of 1920, the Federal Government reserved coal rights on all lands classified as valuable for coal when such lands were sold. Although thousands of acres of coal lands, including coal rights, were sold before 1920, the Federal Government is still the largest single owner of coal lands, or coal rights, in the Rocky Mountain and northern Great Plains regions. The Government-owned coal in these regions and elsewhere is available for lease on a modest royalty basis.

In the early days of construction of the transcontinental railroads, the railroad companies received as a form of subsidy considerable areas of land, including mineral rights, adjoining the right-of-ways. As a result, the western railroads as a group probably hold the second largest acreage of coal land in the West. Many individual States in the West own two or three sections per township, which were allotted originally to help support the State school systems.

In Oklahoma and New Mexico and other States, fairly large acreages of coal land are owned by various Indian tribes. This land is leased and administered by the U.S. Bureau of Indian Affairs.

In Washington and Oregon the percentage of coal land owned privately is somewhat higher than it is in the Rocky Mountain $58696 \mathrm{~S}-61-4$ 
region, but even in these States the Federal Government owns large areas of coal land.

\section{STATE ESTIMATES}

Because somewhat different assumptions and procedures were used to prepare many of the State reserve estimates presented in this report, it is necessary in comparing or evaluating individual estimates to consider how the estimates were obtained. Even in the recent estimates of reserves prepared by the U.S. Geological Survey according to the basic procedures and definitions discussed in a previous section, minor differences in procedure were necessary because of differences in the occurrence of the coal and in the amount of information available. Somewhat greater differences in assumptions and procedures exist between estimates prepared by the State Geological Surveys of Illinois, Kansas, Ohio, Pennsylvania, Tennessee, and West Virginia. For a few States, particularly Iowa, Missouri, Texas (bituminous coal), and Washington, the only estimates available are those prepared by or under the direction of M. R. Campbell before 1928. These are more generalized than modern estimates.

The following State summaries, arranged in alphabetical order, describe and evaluate the various methods followed in preparing individual estimates. Wherever possible, the reserve figures for each State are further classified according to thickness of coalbeds, thickness of overburden, and relative abundance of reliable information, in order to give the estimates additional significance and usefulness.

\section{ALABAMA}

\section{BITUMINOUS COAL}

As estimated by Culbertson (written communication, 1959), the remaining reserves of bituminous coal in Alabama, as of Jan. 1, 1958, totaled 13.8 billion tons, of which 7.9 billion tons is in beds more than 28 inches thick. The total reserves are divided among four coal fields as follows: Warrior field, 11.9 billion tons; Cahaba field, 1.8 billion tons; Coosa field, 41 million tons; and Plateau field, 41 million tons. Except for 15 million tons of low-volatile bituminous coal in northeast Alabama, all the coal is of high-volatile $\mathbf{A}$ or medium-volatile bituminous rank.

The reserves remaining in the Warrior and Cahaba coal fields were determined by first calculating the original reserves in each bed and then subtracting a tonnage equal to twice the production to allow for coal mined and lost in mining. The remaining reserves in the Coosa and Plateau coal fields were calculated directly. 
Estimated remaining bituminous coal reserves of Alabama, January 1, 1958

[In millions of short tons]

\begin{tabular}{|c|c|c|c|c|}
\hline \multirow{2}{*}{$\quad \begin{array}{c}\text { Overburden } \\
\text { (feet) }\end{array}$} & \multirow{2}{*}{$\begin{array}{c}\text { Thickness of bed } \\
\text { (inches) }\end{array}$} & \multicolumn{2}{|c|}{ Reserves' } & \multirow{2}{*}{ Total } \\
\hline & & $\begin{array}{c}\text { Measured } \\
\text { and indi: } \\
\text { cated }\end{array}$ & Inferred & \\
\hline \multirow[t]{2}{*}{0 to 1,000} & \multirow[t]{2}{*}{$\begin{array}{l}14 \text { to } 28 \\
28 \text { to } 42\end{array}>42 \ldots$} & $\begin{array}{r}1,442.0 \\
1,117.1 \\
860.6\end{array}$ & $\begin{array}{l}3,186.1 \\
2,179.0 \\
1,202.6\end{array}$ & $\begin{array}{l}4,628 . \\
3,296 . \\
2,063 .\end{array}$ \\
\hline & & $3,419.7$ & $6,567.7$ & $9,987.4$ \\
\hline 1,000 to $2,000 \ldots$ & \multirow[t]{2}{*}{$\begin{array}{l}14 \text { to } 28 \\
28 \text { to } 42 \\
>42\end{array}$} & $\begin{array}{l}13.8 \\
11.6 \\
39.7\end{array}$ & $\begin{array}{l}1,008.5 \\
1,082.8 \\
1,316.2\end{array}$ & $\begin{array}{l}1.022 .3 \\
1,094.4 \\
1,355.9\end{array}$ \\
\hline . & & 65.1 & $3,407.5$ & $3,472,6$ \\
\hline \multirow[t]{3}{*}{2,000 to $3,000 \ldots$} & \multirow[t]{3}{*}{$\begin{array}{l}14 \text { to } 28 \\
28 \text { to } 42 \\
>42\end{array}$} & \begin{tabular}{|l|}
$\ldots \ldots \ldots$ \\
\hdashline$\cdots \cdots$ \\
$\cdots \cdots$ \\
\end{tabular} & $\begin{array}{r}210.8 \\
74.5 \\
8.4\end{array}$ & $\begin{array}{r}210.8 \\
74.5 \\
8.4\end{array}$ \\
\hline & & 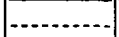 & 293.7 & 293.7 \\
\hline & & $3,484.8$ & $10,268.8$ & $13,753.7$ \\
\hline
\end{tabular}

-The southwestern half of the Warrior coal field was omitted from consideration because of lack of data on the coal-bearing strata, which are under a thick cover of Cretaceous sediments. In the productive part of the Warrior field, however, the coal beds thin and pinch out in a westerly direction; therefore it is not anticipated that large reserves of coal will be found in the southwestern half of the field.

In the Plateau and Coosa fields most of the coalbeds are lenticular, and few data are available on their thickness. Therefore, reserves were estimated in only a few small areas where thickness data were sufficiently dense or where the beds were known to be persistent. Intensive exploration in these coal fields, however, would undoubtedly reveal other small areas underlain by coal of minable thickness.

\section{LIGNITE}

Lignite occurs in Alabama mostly as thin lenticular beds in formations of Cretaceous, Paleocene, and Eocene ages. None of the lignite has been mined commercially. Analyses from outcrops and auger holes indicate that, in general, the Alabama lignite has a relatively low heating value compared with lignite from other States. Sparse evidence indicates that in a few areas lignite beds 4 feet or more thick may be found in Paleocene strata under shallow overburden. One such area, in T. 14 N., R. 1 E., Marengo County, is estimated to contain at least 20 million tons of lignite of a relatively good grade. 


\section{ALASKA}

Coal is known to occur in substantial quantities at many places in Alaska. (See fig. 8.) Detailed mapping or exploration has been carried on in only a few of the coal-bearing areas, however, and only a generalized estimate of the total coal reserves of the State can be made at present. As shown in the accompanying table prepared by F. F. Barnes (written communication, 1959), the original coal reserves of Alaska total 94,638 million tons, including 21,401 million tons of bituminous coal, 71,136 million tons of subbituminous coal and lignite, and 2,101 million tons of anthracite. This estimate is based in part on a previous estimate made by Clyde Wahrhaftig in 1944 and published in an earlier edition of this report (Averitt and others, 1953, p. 37) and in part on later fieldwork by the Geological Survey.

\section{Estimated original coal reserves of Alaska}

[In millions of short tons]

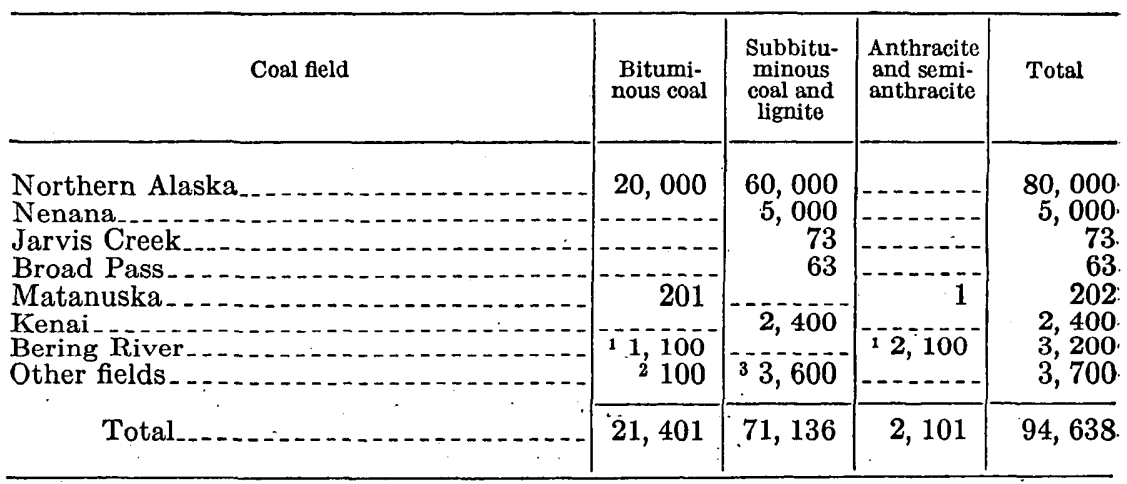

${ }^{1}$ A vailable data suggest that most of the coal in the Bering River field probably is too badly crushed and faulted to be economically recoverable.

2 Includes the Herendeen Bay and Chignik fields.

${ }^{3}$ Includes the Eagle, Susitna, and Unga Island fields.

The coal reserves of most Alaska coal fields cannot be classified by thickness of bed or overburden because of the scarcity of detailed information. Of the total reserves as presently estimated, about $\mathbf{1 . 5}$ billion tons, or 1.6 percent, is based on detailed surveys and is classified according to standard U.S. Geological Survey definitions and procedures. Most of this coal is in the Nenana, Jarvis Creek, Broad Pass, Matanuska, and Kenai fields,. which are reasonably accessible by road or railroad. The much larger remainder is based on reconnaissance surveys in more remote areas, and the estimated reserves cannot be classified in the usual detail. The total figure thus derived is intended to give the general order of magnitude of the coal potential of the State. 


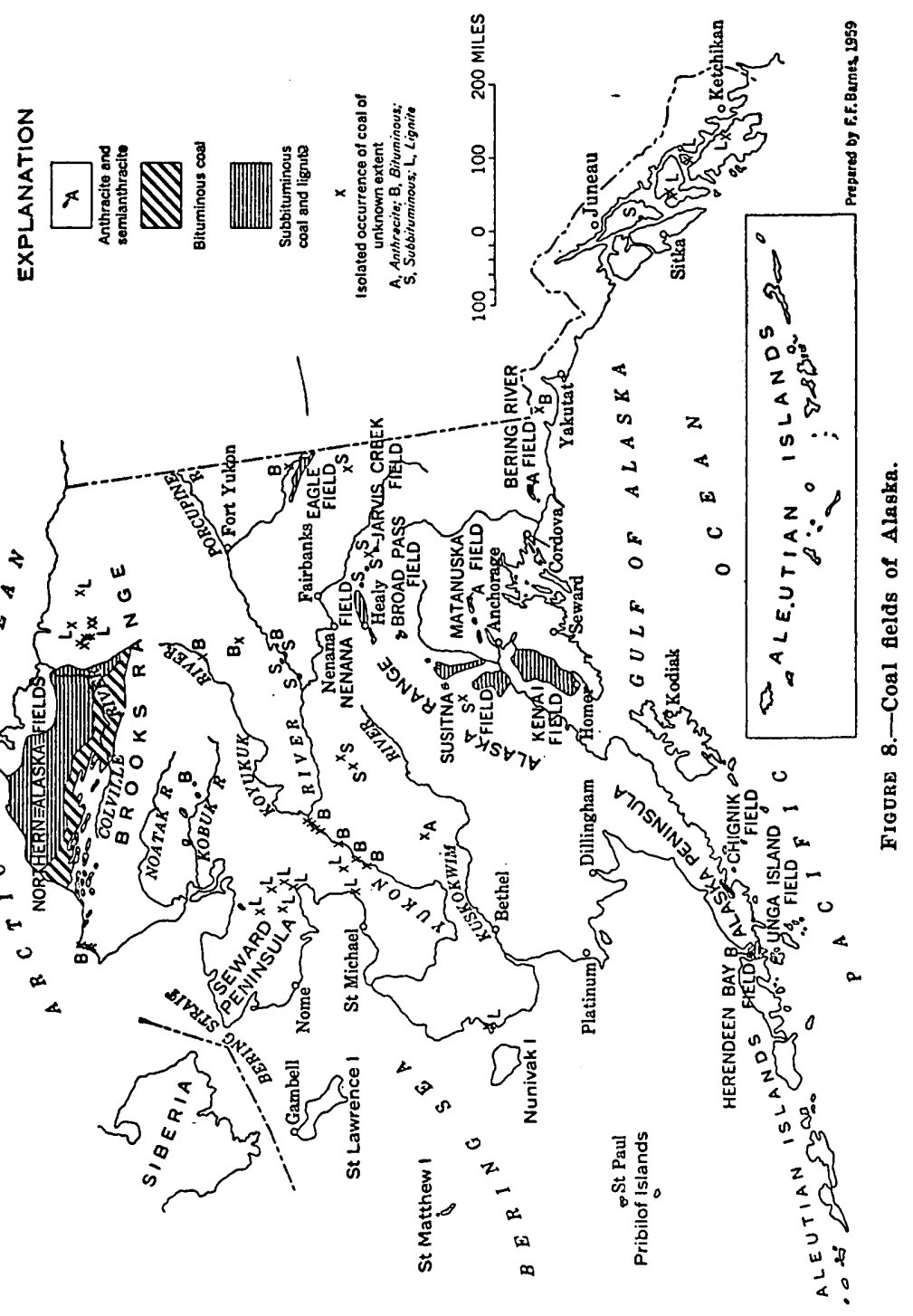


By Jan. 1, 1959, the total recorded production of coal in Alaska was 11.9 million tons, most of which came from the Matanuska and Nenana coal fields on the Alaska Railroad. High costs of mining and shipping limit Alaska coal to use within the State.

\section{ARKANSAS}

As estimated by Haley (1960), the original coal reserves of Arkansas total 2,622 million tons, of which 1,816 million tons is low-volatile bituminous coal, 456 million tons is semianthracite, and 350 million tons is lignite.

\section{BITUMINOUS COAL AND SEMIANTHRACITE}

The reserves of coal other than lignite were calculated and classified according to standard U.S. Geological Survey procedures as previously defined, except that five categories of overburden were used instead of the usual three. These 5 categories, according to

Estimated original coal reserves of Arkansas

[In millions of short tons]

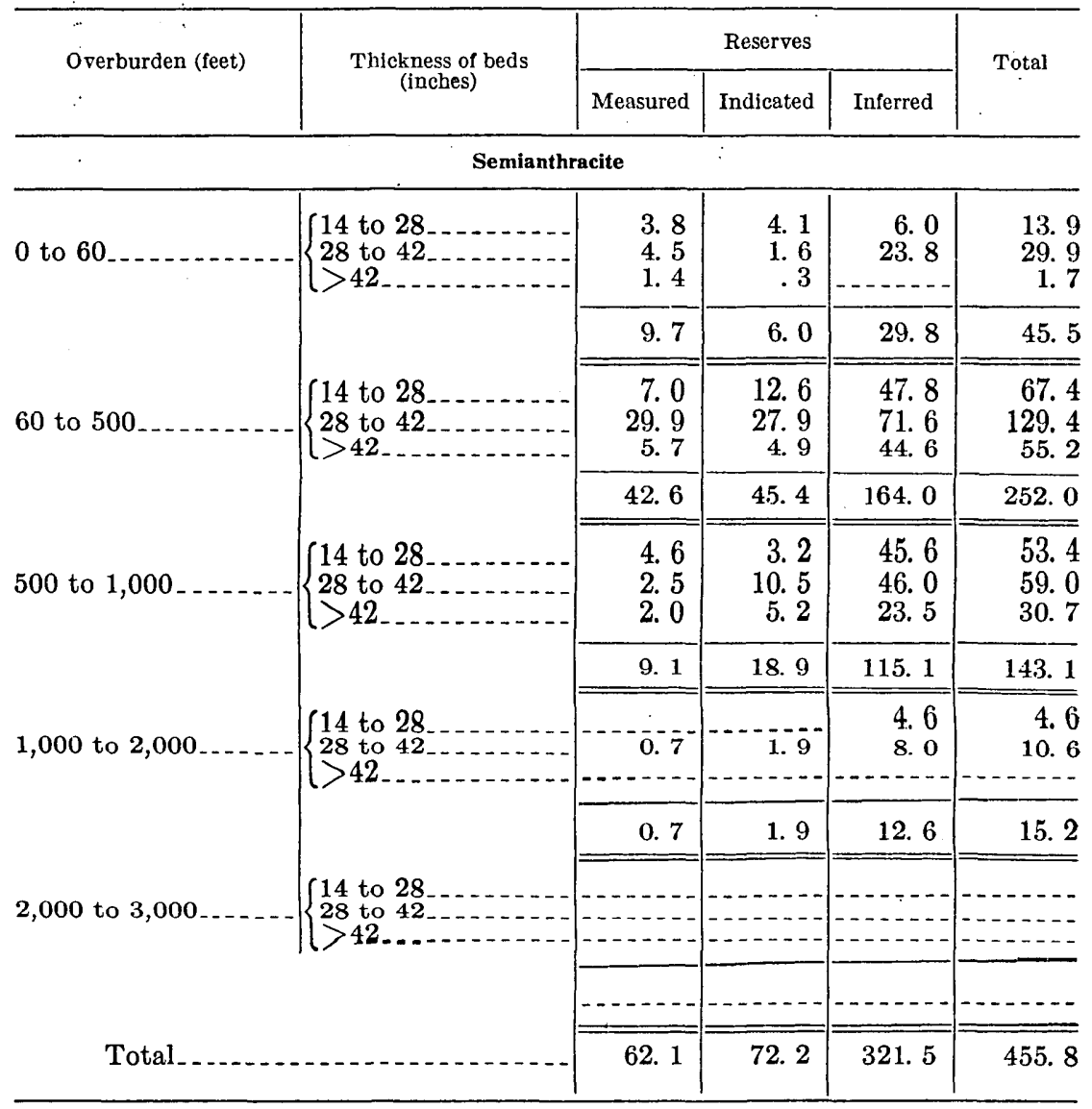


Estimated original coal reserves of Arkansas-Continued

. [In millions of short tons]

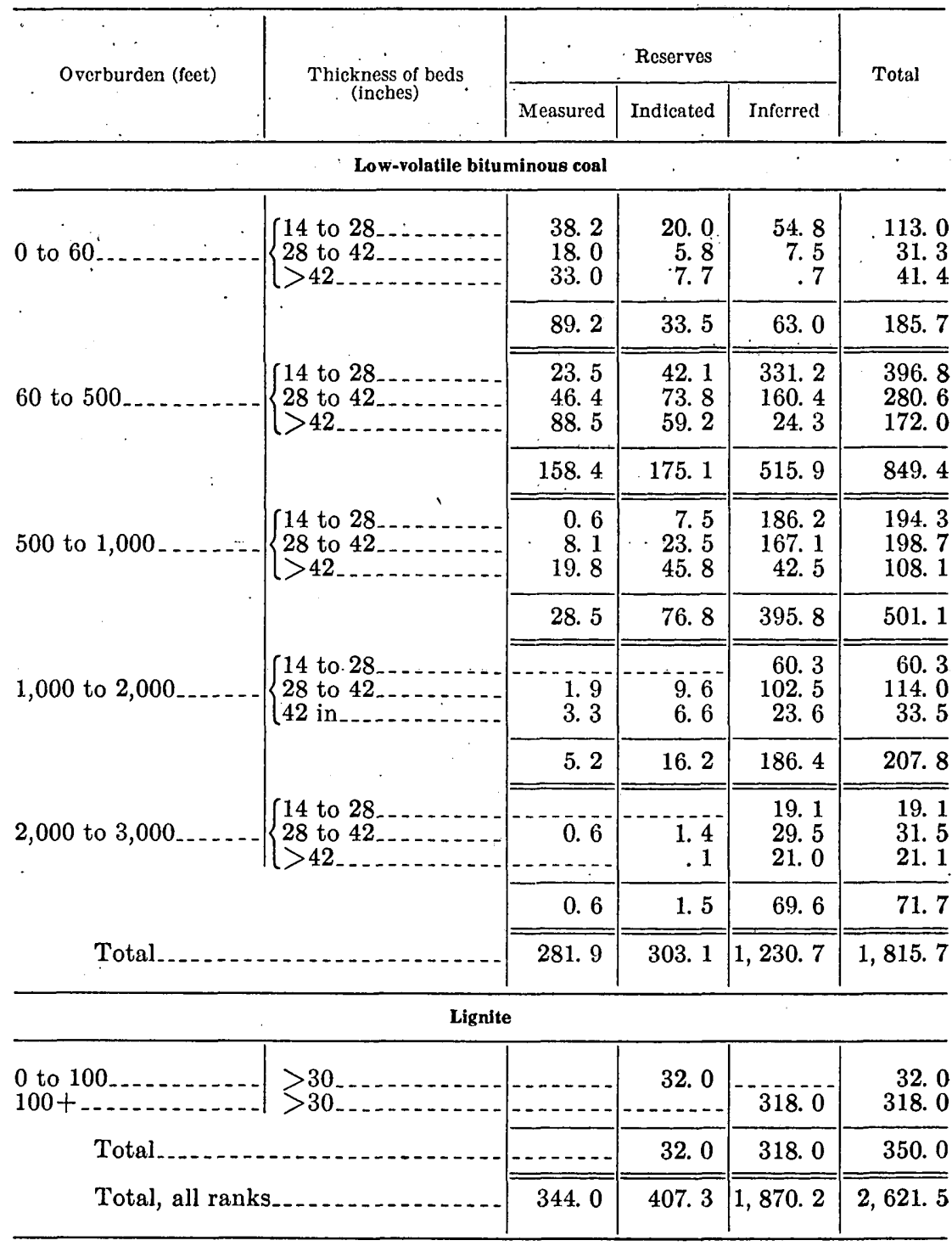

thickness, in feet, were as follows: 0 to 60,60 to 500,500 to 1,000 , 1,000 to 2,000 , and 2,000 to 3,000 feet. The 0 - to 60 -foot category was intended to aid in determining the quantity of strippable coal in the State.

The distribution of original reserves of bituminous coal and semianthracite in Arkansas in various categories is given in the accompanying table. As recorded in the table, the 60- to 500-foot overburden category contains the largest reserves, and successively smaller amounts are present in deeper categories. 
By far the larger proportion of Arkansas reserves is concentrated in seven counties in the Arkansas Valley coal field, namely, Crawford, Franklin, Johnson, Logan, Pope, Scott, and Sebastian. The coal-bearing rocks of this area contain at least 19 coal beds of which 4, the Lower and Upper Hartshorne, Charleston (Philpot), and Paris, contain coal of present commercial interest. All the reserves calculated for the Arkansas Valley field are contained in these four beds.

The distribution of original reserves in the Arkansas Valley field according to county and coalbed is shown in the accompanying table. As recorded in the table, the larger proportion of the estimated original reserves is in the Lower Hartshorne bed and in Sebastian County.

Distribution of original reserves of bituminous coal and semianthracite in the Arkansas Valley field according to county and bed

[In millions of short tons]

\begin{tabular}{|c|c|c|c|c|c|}
\hline \multirow{2}{*}{ County } & \multicolumn{5}{|c|}{ Bed } \\
\hline & $\begin{array}{c}\text { Lower } \\
\text { Hartshorne }\end{array}$ & $\begin{array}{c}\text { Upper } \\
\text { Hartshorne }\end{array}$ & $\begin{array}{l}\text { Charleston } \\
\text { (Philpot) }\end{array}$ & Paris & Total \\
\hline $\begin{array}{l}\text { Crawford. } \\
\text { Franklin } \\
\text { Johnson } \\
\text { Logan } \\
\text { Pope } \\
\text { Scott } \\
\text { Sebastian }\end{array}$ & \begin{tabular}{r|}
289.9 \\
181.3 \\
336.7 \\
166.5 \\
23.4 \\
104.2 \\
$1,014.2$
\end{tabular} & 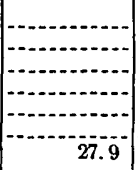 & $\begin{array}{r}40.3 \\
25.1 \\
-4 \\
\hdashline 20.9 \\
\hdashline\end{array}$ & 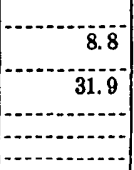 & $\begin{array}{r}289.9 \\
230.4 \\
361.8 \\
198.8 \\
23.4 \\
104.2 \\
1,063.0\end{array}$ \\
\hline Total_............... & $\overline{2,116.2}$ & 27.9 & $\overline{86.7}$ & $\overline{40.7}$ & $2,271.5$ \\
\hline
\end{tabular}

LIGNITE

Lignite occurs sporadically in thin beds in 17 counties in the Coastal Plain region of Arkansas. In general, the beds cannot be traced or correlated with any certainty over distances greater than half a mile, and for this reason the estimated reserves must be classed as indicated or inferred.

As estimated by Haley (1960), the indicated original reserves of lignite in beds 30 inches or more thick and lying less than 100 feet below the surface total 32 million tons. Most of the lignite in this category is in Pulaski, Saline, Ouachita, and Dallas Counties. The inferred original reserves in beds of the same thickness, but lying at depths of more than 100 feet below the surface, total 318 million tons.

\section{COLORADO}

The original coal reserves of Colorado, as estimated by Landis (1959), total 81,785 million tons, of which 90 million tons is anthra- 
cite and semianthracite, 63,203 million tons is bituminous coal, and 18,492 million tons is subbituminous coal. The reserves were calculated and classified according to standard U.S. Geological Survey procedures and definitions with two minor exceptions as follows: The categories of measured and indicated reserves were combined in a single category termed "Measured and indicated," and in some parts of the State the reserves were calculated on a coal-zone basis. rather than on an individual bed basis. This procedure was necessary because in some areas the coal-bearing zones are very persistent even though individual beds may be of limited extent. Reserves calculated on a coal-zone basis usually cannot be assigned to the standard thickness categories, and in some areas the reserves cannot be assigned to the standard overburden categories. Most of the reserves estimated on a coal-zone basis are included in the inferred reserves category and are segregated in the accompanying table.

The estimated reserves in Colorado are contained in an area of 5,276 square miles, mostly confined to the edges of the coal-bearing basins. It is estimated that a total area of about 20,600 square miles in Colorado may contain minable reserves less than 3,000 feet below the surface. No estimates were made for the probable reserves in the remaining area of about 15,000 square miles because the coal is remote from outcrops and little information is available as to the thickness and continuity of the coal beds. An additional area of 9,000 square miles is underlain by coal-bearing rocks at depths greater than 3,000 feet. As exploration and development of Colorado coal continues into the future, it is certain that the estimated reserves will be increased.

Because of lack of detailed data on the thickness of overburden no attempt was made to differentiate strippable coal from coal that will have to be mined by underground methods. The amount of coal that can be mined by stripping methods is, however, very small as compared to the total amount of coal in Colorado. Nevertheless, the relatively few strip mines in the State produce a significant part of the total annual production. In 1955, for example, less than 5 percent of the operating mines in Colorado were strip mines, but they yielded almost 11 percent of the total production.

Coking coal is present in Colorado in the Trinidad, Somerset, Crested Butte, and Carbondale fields. This coal ranges in rank from high-volatile to low-volatile bituminous, but most is high volatile. The total original reserves of coal in Colorado with coking properties is probably more than 10,000 million tons. 
Estimated original coal reserves of Colorado

[In millions of short tons]

\begin{tabular}{|c|c|c|c|c|}
\hline \multirow{2}{*}{ Overburden (feet) } & \multirow{2}{*}{ Thickness of bed (inches) } & \multicolumn{3}{|c|}{ Reserves } \\
\hline & & $\begin{array}{l}\text { Measured } \\
\text { and } \\
\text { indicated }\end{array}$ & Inferred & Total \\
\hline \multicolumn{5}{|c|}{ Anthracite and semianthracite } \\
\hline \multirow[t]{2}{*}{0 to 1,000} & \multirow[t]{2}{*}{$\begin{array}{l}14 \text { to } 28 \\
28 \text { to } 42\end{array}$} & $\begin{array}{r}4.07 \\
12.36 \\
15.37\end{array}$ & $\begin{array}{r}5.52 \\
10.13 \\
10.64\end{array}$ & $\begin{array}{r}9.59 \\
22.49 \\
26.01\end{array}$ \\
\hline & & 31.80 & 26.29 & 58.09 \\
\hline \multirow[t]{2}{*}{1,000 to $2,000 \ldots$} & \multirow[t]{2}{*}{$\begin{array}{l}14 \text { to } 28 \ldots \\
28 \text { to } 42 \ldots \ldots\end{array}$} & $\begin{array}{l}0.69 \\
2.42 \\
4.23 \\
\end{array}$ & $\begin{array}{l}2.65 \\
5.04 \\
4.43\end{array}$ & $\begin{array}{l}3.34 \\
7.46 \\
8.66\end{array}$ \\
\hline & & 7.34 & 12.12 & 19.46 \\
\hline \multirow[t]{2}{*}{2,000 to $3,000 \ldots$} & \multirow[t]{3}{*}{$\begin{array}{l}14 \text { to } 28 \\
28 \text { to } 42\end{array}$} & $\begin{array}{r}0.50 \\
.96 \\
\end{array}$ & $\begin{array}{l}1.59 \\
2.32 \\
7.46 \\
\end{array}$ & $\begin{array}{l}1.59 \\
2.82 \\
8.42 \\
\end{array}$ \\
\hline & & 1.46 & 11.37 & 12.83 \\
\hline Total $\ldots \ldots$ & & 40.60 & 49.78 & 90.38 \\
\hline \multicolumn{5}{|c|}{ Bituminous coal } \\
\hline \multirow[t]{2}{*}{0 to $1,000 \ldots$} & \multirow[t]{2}{*}{$\begin{array}{l}14 \text { to } 28 \\
28 \text { to } 42 \\
\text { Unclassified }\end{array}$} & $\begin{array}{r}966.42 \\
1,476.90 \\
8,168.63 \\
40.39 \\
\end{array}$ & $\begin{array}{l}1,134.92 \\
1,341.60 \\
4,209.58 \\
5,205.64 \\
\end{array}$ & $\begin{array}{r}2,101.34 \\
2,818.50 \\
12,378.21 \\
5,246.03 \\
\end{array}$ \\
\hline & & $10,652.34$ & $11,891,74$ & $22,544.08$ \\
\hline \multirow[t]{2}{*}{1,000 to $2,000 \ldots$} & \multirow[t]{2}{*}{$\begin{array}{l}14 \text { to } 28 \\
28 \text { to } 42 \\
742\end{array}$} & $\begin{array}{r}157.53 \\
356.73 \\
3,177.11 \\
55.54 \\
\end{array}$ & $\begin{array}{r}284.55 \\
495.21 \\
3,841.42 \\
6,478.62 \\
\end{array}$ & $\begin{array}{r}442.08 \\
851.94 \\
7,018.53 \\
6.534 .16 \\
\end{array}$ \\
\hline & & $3,746.91$ & $11,099.80$ & $14,846.71$ \\
\hline \multirow[t]{2}{*}{2,000 to $3,000 \ldots$} & \multirow[t]{2}{*}{$\begin{array}{l}14 \text { to } 28 \\
28 \text { to } 42 \\
822 \\
\text { Unclassified. }\end{array}$} & $\begin{array}{r}27.40 \\
70.09 \\
562.19 \\
\end{array}$ & $\begin{array}{r}190.23 \\
224.91 \\
1,648.66 \\
4,100.42\end{array}$ & $\begin{array}{r}217.63 \\
295.00 \\
2,210.85 \\
4,100.42 \\
\end{array}$ \\
\hline & & 659.68 & $6,164.22$ & $6,823.90$ \\
\hline \multirow[t]{2}{*}{0 to $3,000 \ldots$} & \multirow[t]{3}{*}{$\begin{array}{l}14 \text { to } 28 \ldots \ldots \\
28 \text { to } 42 \\
>42 \\
\text { Unclassified }\end{array}$} & $\begin{array}{r}4.90 \\
11.90 \\
33.80 \\
\end{array}$ & $\begin{array}{r}7.10 \\
7.60 \\
4.50 \\
18,918.66 \\
\end{array}$ & $\begin{array}{r}12.00 \\
19.00 \\
38.30 \\
18,918.66 \\
\end{array}$ \\
\hline & & 50.10 & $18,937.86$ & $18,987.96$ \\
\hline Total & & $15,109.03$ & $48,093.62$ & $63,202.65$ \\
\hline \multicolumn{5}{|c|}{ Subbituminous coal } \\
\hline \multirow{3}{*}{0 to 1,000} & Thickness of bed (feet) & & & \\
\hline & \multirow[t]{2}{*}{$\begin{array}{l}21 / 2 \text { to } 5 \ldots \ldots \\
5 \text { to } 10 \\
>10\end{array}$} & $\begin{array}{r}1,705.42 \\
2,346.44 \\
2,366.69 \\
\end{array}$ & $\begin{array}{l}1,353.19 \\
1,462.14 \\
1,904.80 \\
3,034.49\end{array}$ & $\begin{array}{l}3,058.61 \\
3,808.58 \\
4,331.49 \\
3,034.49\end{array}$ \\
\hline & & $6,418.55$ & $7,814.62$ & $14,233.17$ \\
\hline 1,000 to $2,000 \ldots$ & $\left\{\begin{array}{l}216 \text { to } 5 \\
5 \text { to } 10 \ldots\end{array}\right.$ & $\begin{array}{r}66.74 \\
174.18 \\
741.52 \\
\end{array}$ & $\begin{array}{r}290.31 \\
1,047.77 \\
658.34 \\
\end{array}$ & $\begin{array}{r}357.05 \\
1,221.95 \\
1,399.86 \\
\end{array}$ \\
\hline \multirow{3}{*}{2,000 to 3,000} & \multirow{3}{*}{$\begin{array}{l}216 \text { to } 5 \ldots \ldots \ldots \\
5 \text { to } 10\end{array}$} & 982.44 & $1,996.42$ & $2,978.86$ \\
\hline & & $\begin{array}{r}31.35 \\
22.97 \\
426.98 \\
\end{array}$ & $\begin{array}{r}34.79 \\
190.54 \\
572.94 \\
\end{array}$ & $\begin{array}{r}66.14 \\
213.51 \\
999.92 \\
\end{array}$ \\
\hline & & 481.30 & 798. 27 & $1,279.57$ \\
\hline \multicolumn{2}{|c|}{ 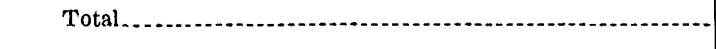 } & $7,882.29$ & $10,609.31$ & $18,491.60$ \\
\hline
\end{tabular}




\section{GEORGIA}

The original coal reserves of Georgia are here assumed to be 100 million tons on the basis of work by Sullivan (1942, p. 45-51), Johnson (1946), and Butts and Gildersleeve (1948, p. 109). 'This figure has been selected to reconcile the estimates of 198,40 , and 155 million tons, respectively, as published or derived from the data published by the three workers. Most of the difference between the three estimates is due to differences in the assumptions on which they were based, and it can be shown by an analysis of the estimates that the figure of 100 million tons is a fair approximation of the original reserves in all categories in all beds 14 inches or more thick.

The coal-bearing rocks in Georgia cover about 170 square miles in parts of Dade, Walker, and Chattooga Counties in the northwestern part of the State. The geology of this area is described in a report by McCallie (1904), which includes much useful information about the coal but does not include estimates of reserves. Each of the three recent reports mentioned above describes only the Sand and Lookout Mountains area in Dade and Walker Counties, which covers about 120 square miles or about 70 percent of the total coal-bearing area. At least 11 coalbeds have been identified in the Sand and Lookout Mountains area, but mining on a commercial scale has been limited to 5 or 6 beds, which, in general, are considered to contain all the reserves.

The area to the south, which is not considered in the three reports, covers about 30 percent of the total coal-bearing area in Georgia, but the coalbeds are reported to be thinner and less extensive than those in the area to the north.

Sullivan (1942, p. 45-51), who prepared the first of the three reports on the Sand and Lookout Mountains area, calculated original reserves for 5 coalbeds and arrived at a total of 198 million tons. $\mathrm{He}$ omitted reserves in the Durham (No. 3) bed and the A (No. 1) bed which, although of small areal extent, have been computed in other estimates; but he included the Red Ash bed, which is reported to be generally less than 14 inches thick and is not included in other estimates. Other assumptions used in preparing the Sullivan estimate were not specified in the report.

Johnson (1946), who prepared the second report on the Sand and Lookout Mountains area, estimated that the remaining coal reserves as of 1945 totaled about 24 million tons and that the original reserves totaled about 40 million tons (oral communication, 1953). This estimate includes the reserves in 5 beds with average thicknesses ranging from 1.3 to 3.3 feet.

Butts and Gildersleeve (1948, p. 109), who prepared the third report on the area, considered the reserves in 6 beds with average 
thicknesses ranging from 2.0 to 3.3 feet. They listed for each bed the average thickness, acreage, percentage of area mined out, and percentage of the area unworkable. Assuming that the coal weighs 1,800 tons per acre-foot, calculations based on their data show that the original workable reserves totaled 155 million tons, of which 35 million tons had been mined out as of the date of their estimate.

The estimates made by Sullivan and by Butts and Gildersleeve are considerably larger than the estimate made by Johnson. Much of this difference may be attributed to different interpretations of the Dade and the Rattlesnake beds. Johnson considered Dade and Rattlesnake as local names for a single coalbed, the No. 9 bed of his report, which in his estimate accounts for about 1 percent of the total estimated reserves. Sullivan and Butts and Gildersleeve, however, considered them to be two separate beds, which in their estimates account for more than 70 percent of the estimated coal reserves. If only one bed is assumed to be present, in the interest of conservatism, the Butts and Gildersleeve estimate would be reduced to something between 89 to 103 million tons, and the Sullivan figure would range from 97 to 156 million tons.

Although Johnson's figure of 40 million tons is based conservatively on careful detailed work, the fact that other later workers arrived at higher figures, and the fact that about 30 percent of the coal-bearing areas is not covered by recent detailed mapping suggest that a higher figure should be selected for the original reserves of the State. The 100-million figure selected to serve this purpose is intermediate between the published figures and should be serviceable until further detailed work is done.

\section{ILIINOIS}

As estimated by the Illinois Geological Survey (Cady and others, 1952), the remaining coal reserves of Illinois on Jan. 1, 1950, totaled 137,329 million tons, all of which is of bituminous rank. In preparing this estimate the minimum thickness of coal considered was 28 inches, except for areas of strippable coal where an average thickness of 24 inches was used. Coal underlying large towns was not included; nor was coal underlying known oil fields and areas of closely spaced rotary drilling, except for an area in Franklin County, where such drilling was done in close cooperation with active mining. About 90 percent of the estimated reserves is less than 1,000 feet below the surface; the remainder is between 1,000 and 1,200 feet below the surface. 
A fourfold classification of reserves was used in the Illinois Geological Survey estimate as follows: I-A, proved reserves; I-B, probable reserves; II-A, strongly indicated reserves; and II-B, weakly indicated reserves.

Class I-A, proved reserves, includes coal extending no more than. one-half mile from a mined-out area, diamond-drill hole, or an outcrop. This category corresponds approximately to the measured reserve category of the U.S. Geological Survey.

Class I-B, probable reserves, includes coal extending no more than 2 miles from a mined-out area, diamond-drill hole, outcrop, or churn-drill hole known to have been drilled for coal. This category corresponds approximately to the indicated reserve category of the U.S. Geological Survey.

Class II-A, strongly indicated reserves, includes coal extending no more than 4 miles from a mined-out area; diamond-drill hole; outcrop; churn-drill coal test hole; churn-drill hole drilled for oil, gas, or water, if sufficiently detailed logs were available; and "control" rotary-drill holes that were sampled and logged in the field by members of the Illinois Geological Survey.

Class II-B, weakly indicated reserves, includes coal in areas not inçluded in previous categories, where geologic information suggested that the coal was at least 28 inches thick. All reserves in this category were calculated on the assumed minimum thickness of 28 inches.

Where the strict application of the above definitions produced a number of closely spaced areas all in the same category, and the coal was known to be relatively uniform, the areas were joined.

In all calculations the coal was assumed to weigh 1,800 tons per acre-foot. Where data permitted, isopach lines were drawn on the coalbeds at 28 inches, 42 inches, and at succeeding 1-foot intervals; and reserves were calculated in each of these categories. If the data were too widely spaced to permit the use of isopachs, average thicknesses were estimated for each township.

The results of the Illinois Geological Survey study are summarized in the accompanying table, which presents the total remaining reserves in Illinois as of Jan. 1, 1950, classified by beds and by reserve categories. The report by Cady and others (1952) gives the data in greater detail by beds, counties, reserve categories, and thickness categories, and includes maps of the individual coalbeds.

It should be noted that the Illinois estimate, which is for remaining reserves as of Jan. 1, 1950, in beds more than 28 inches thick, is markedly more conservative than estimates for some other States, which are for original reserves in beds more than 14 inches thick. 
[In millions of short tons]

\begin{tabular}{|c|c|c|c|c|c|}
\hline \multirow{2}{*}{ Coalbed } & \multicolumn{5}{|c|}{ Reserve category } \\
\hline & $\begin{array}{l}\text { I-A } \\
\text { Proved }\end{array}$ & $\begin{array}{c}\mathrm{I}-\mathrm{B} \\
\text { Probable }\end{array}$ & $\begin{array}{c}\text { II-A } \\
\text { Strongly } \\
\text { indicated }\end{array}$ & $\begin{array}{c}\text { II-B } \\
\text { Weakly } \\
\text { indicated }\end{array}$ & Total \\
\hline $\begin{array}{l}\text { Trowbridge } \\
\text { Friendsville } \\
\text { Danville (Sparland) No. } 7 \\
\text { Herrin No, } 6 \text { (includes Grape Creek) }\end{array}$ & $\begin{array}{r}8 \\
1,003 \\
42 \\
12,300\end{array}$ & $\begin{array}{r}8 \\
25 \\
3,413 \\
191 \\
21,101\end{array}$ & $\begin{array}{r}70 \\
2,924 \\
368 \\
25,144\end{array}$ & $\begin{array}{r}5 \\
500 \\
4,093\end{array}$ & $\begin{array}{r}16 \\
100 \\
7,840 \\
601 \\
62,638\end{array}$ \\
\hline $\begin{array}{l}\text { Harrisburg (Springfield) No. } 5 \\
\text { Summum No. } 4 \\
\text { Indiana IV } \\
\text { La Salle (Colchester) No. } 2 \\
\text { Dekoven......... }\end{array}$ & $\begin{array}{r}4,168 \\
52 \\
12 \\
1,359 \\
92\end{array}$ & $\begin{array}{r}9,593 \\
62 \\
58 \\
3,623 \\
845\end{array}$ & $\begin{array}{r}19,777 \\
68 \\
61 \\
6,216 \\
1,548\end{array}$ & $\begin{array}{r}4,972 \\
-6,288 \\
-\end{array}$ & $\begin{array}{r}38,510 \\
182 \\
131 \\
17,486 \\
2,485\end{array}$ \\
\hline $\begin{array}{l}\text { Indiana III. } \\
\text { Davis-Wiley } \\
\text { Stonefort } \\
\text { Bald Hill } \\
\text { Campbell Hill }\end{array}$ & $\begin{array}{r}168 \\
123 \\
5 \\
27 \\
9\end{array}$ & $\begin{array}{r}688 \\
1,062 \\
39\end{array}$ & $\begin{array}{r}965 \\
1,883 \\
5\end{array}$ & 364 & $\begin{array}{r}1,821 \\
3,432 \\
5 \\
72 \\
9\end{array}$ \\
\hline $\begin{array}{l}\text { Murphysboro } \\
\text { Rock Island No. } 1 \\
\text { Assumption-Litchfield. } \\
\text { Willis } \\
\text { Makanda. }\end{array}$ & $\begin{array}{r}34 \\
111 \\
28 \\
7 \\
2\end{array}$ & $\begin{array}{r}86 \\
65 \\
266 \\
\end{array}$ & $\begin{array}{r}147 \\
86 \\
1,011\end{array}$ & $\begin{array}{r}124 \\
7 \\
-2\end{array}$ & $\begin{array}{r}391 \\
269 \\
1,305 \\
7 \\
2\end{array}$ \\
\hline $\begin{array}{l}\text { Coalbeds of unknown correlation below } \\
\text { No. } 6 \text {. }\end{array}$ & 21 & & 6 & & 27 \\
\hline Total & 19,571 & 41,125 & 60,279 & 16,354 & 137,329 \\
\hline
\end{tabular}

\section{INDIANA}

As estimated by Spencer (1953), the original coal reserves of Indiana totaled 37,293 million tons, all of which is of bituminous rank. This figure includes remaining reserves as of Jan. 1, 1951, totaling 35,806 million tons, plus an estimate of coal mined and lost in mining to Jan. 1, 1951, totaling 1,487 million tons. The tonnage estimated as mined and lost in mining was computed from information on available maps of mined-out areas and is, therefore, a minimum figure. For this reason, and also for the sake of simplicity, the larger figure of two times past production has been used in tables 1 and 2.

All the estimated reserves are less than 1,000 feet below the surface, and 3,524 million tons, or about 9.5 percent of the total, is less than 90 feet below the surface and is classified as strippable.

The estimated recoverable reserves, based on an assumed 80 percent recovery for strippable coal and on 50 percent recovery for nonstrippable coal, totaled 18,779 million tons as of Jan. 1, 1951.

The reserves were calculated and classified according to standard U.S. Geological Survey procedures and definitions, but additional categories were established for the strippable reserves. The coalbeds under 90 feet or less of overburden were considered strippable pro- 
viding the ratio of overburden thickness to the coalbed thickness was no more than 20 to 1 . Where the information was adequate and where the ratio of overburden to bed thickness was small enough to classify the coal as strippable, the reserves were classified into one of three overburden categories, in feet, as follows: 0 to 40,0 to 60,0 to 90 .

The accompanying table shows the estimated original coal reserves of Indiana, classified according to various reserve categories.

Estimated original coal reserves of Indiana

[In millions of short tons]

\begin{tabular}{|c|c|c|c|c|c|}
\hline \multirow{2}{*}{ Overburden } & \multirow{2}{*}{$\begin{array}{l}\text { Thickness of bed } \\
\text { (inches) }\end{array}$} & \multicolumn{3}{|c|}{ Reserves } & \multirow{2}{*}{ Total } \\
\hline & & Measured & Indicated & Inferred & \\
\hline \multirow[t]{2}{*}{ Strippable, $90 \mathrm{ft}$ or less. } & \multirow[t]{2}{*}{$\begin{array}{l}14 \text { to } 28 \\
28 \text { to } 42 \ldots 42\end{array}$} & $\begin{array}{r}71 \\
308 \\
1,572\end{array}$ & $\begin{array}{l}112 \\
306 \\
672\end{array}$ & $\begin{array}{r}41 \\
112 \\
330\end{array}$ & $\begin{array}{r}224 \\
726 \\
2,574\end{array}$ \\
\hline & & 1,951 & 1.090 & 483 & 3,524 \\
\hline \multirow[t]{2}{*}{ Nonstrippable, more than $90 \mathrm{ft}$. } & \multirow[t]{2}{*}{$\begin{array}{l}14 \text { to } 28 \\
28 \text { to } 42\end{array}>42$} & $\begin{array}{r}264 \\
430 \\
3,710\end{array}$ & $\begin{array}{r}767 \\
1,600 \\
5,200\end{array}$ & $\begin{array}{r}1,085 \\
4,877 \\
15,836\end{array}$ & $\begin{array}{r}2,116 \\
6,907 \\
24,746\end{array}$ \\
\hline & & 4,404 & 7,567 & 21,798 & 33,769 \\
\hline Total............. & $\ldots$ & 6,355 & 8,657 & 22,281 & 37,293 \\
\hline
\end{tabular}

\section{IOWA}

The original coal reserves of Iowa total 29,160 million tons, all of bituminous rank, according to an early estimate by Campbell and Parker (1909). This estimate is intended to include all classes of reserves in beds 14 inches or more thick throughout the area of coalbearing rocks in Iowa. Persons familiar with the geology and past coal production in Iowa feel that the estimate is high as compared to the more recent estimate for Kansas. For example, Rice (1921), who prospected for coal in Iowa for many years, has stated that less than 25 percent of the area of the large Des Moines River district contains workable coal.

Considering the age of the Campbell estimate and the Rice statement, it is obvious that a revision of the Campbell estimate is in order. Up to the present, however, it has not been possible to prepare a new estimate, and the Campbell estimate has been retained in tables 1 and 2 with the above qualifying remarks.

The main problem in establishing a useful, valid estimate of Iowa coal reserves is the blanket of glacial drift that conceals most of the area of coal-bearing rocks. This blanket ranges from a few feet to several hundred feet thick, except along the courses of the 
major streams. For this reason information on the occurrence and distribution of coal is less abundant than elsewhere and can be significantly increased only by exploratory drilling.

Nevertheless, Iowa must contain considerable quantities of coal, for coal-bearing rocks cover an area of 23,100 square miles, or 41 percent of the total area of the State.

It is to be hoped that a systematic collection and analysis of the data available on Iowa coal can be undertaken in the near future.

\section{RANSAS}

\section{BITUMINOUS COAL}

The estimated remaining reserves of bituminous coal in Kansas as of Jan. 1, 1950, total 20,774 million tons, which include 1,245 million tons of proved reserves and 19,529 million tons of potential reserves. This estimate is a revision by Schoewe (1951a) of an earlier appraisal by Abernathy and others (1947). The new figures differ from previously published figures in part because of recent studies by Schoewe, which show that 15 million tons of coal in Linn County, Kans., previously classified as potential should be reclassified as proved, and in part because of a revision in the assumed weight of the coal in the ground. In the 1947 estimate the coal was assumed to weigh 1,500 tons per acre-foot, whereas in the 1951 estimate it was assumed to weigh 1,800 tons per acre-foot.

Proved reserves were defined as reserves lying within a reasonable distance from a known occurrence of coal, based on the experience of the coal industry and on geological observations of the continuity of coal beds in Kansas. In general, the category of proved reserves includes only beds that can be mined with profit under existing conditions. In calculating proved reserves, a measured thickness of the coalbed was considered to prove the presence of coal of the same thickness in an area of 1 square mile. Two or more known occurrences of the same coalbed in a distance of 4 miles or less along the general line of strike were assumed to prove the bed to be continuous between these points.

In calculating potential reserves, a measured thickness of coal indicated the presence of coal at the same thickness under 400 square miles.

The maximum overburden used in outlining areas of proved reserves was 1,200 feet, and the maximum overburden for potential reserves was 3,000 feet.

In estimating proved reserves the minimum thickness considered minable by underground methods at various depths is shown in the following tabulation: 


$$
150
$$

200

600

1,200

A minimum thickness of 10 inches was assumed in estimating potential reserves and strippable coal reserves.

Strippable coal was defined as coal lying not more than 60 feet below the surface, or coal having an overburden of not more than 35 cubic yards per ton.

\section{LIGNITE}

As estimated by Schoewe (1952) the original reserves of lignite in Kansas total 198 million tons, including 55 million tons of marginal reserves and 143 million tons of alleged reserves. These two terms were applied, rather than the terms "proved" and "potential," which were used for bituminous coal, because the lignite is extremely variable in thickness and pertinent information was scarce. Marginal lignite reserves were defined as reserves in beds 30 inches or less thick. Alleged reserves, which are not associated with any mining activity, were defined as reserves in beds, the extent and thickness of which are suggested by broad geologic field relations. In estimating marginal reserves, the lignite was assumed to extend for a radius of half a mile from isolated points of measured thickness. The minimum average thickness considered was 12 inches; the maximum overburden employed was 1,000 feet; and the lignite was assumed to weigh 1,750 tons per acre-foot.

Because most of the lignite in Kansas is contained in beds less than the minimum of 30 inches used in other areas, this estimate is not included in tables 1 and 2.

\section{KENTUCKY}

As estimated by Huddle and others (in press) the estimated original coal reserves of Kentucky total 72,318 million tons, of which 33,440 million tons is in eastern Kentucky and 38,878 million tons is in western Kentucky. All this coal is of bituminous rank. The estimate for eastern Kentucky was prepared according to standard U.S. Geological Survey procedures. It is based on a large amount of detailed and reconnaissance geologic mapping, supplemented by exploratory data from mining and drilling companies. The estimate for western Kentucky was obtained by extrapolation of reserve data from adjoining States and is not classified in detail.

The accompanying table shows the distribution of reserves in eastern Kentucky in several reserve categories: 
Estimated original coal reserves of eastern Kentucky ${ }^{1}$

[In billions of short tons]

\begin{tabular}{|c|c|c|c|c|}
\hline \multirow{2}{*}{ Thickness of beds (inches) } & \multicolumn{3}{|c|}{ Reserves } & \multirow{2}{*}{ Total } \\
\hline & Measured & .Indicated & Inferred & \\
\hline $\begin{array}{l}14 \text { to } 28 \\
28 \text { to } 42 \\
>42\end{array}$ & $\begin{array}{l}\text { 1. } 4 \\
\text { 3. } 2 \\
4.5 \\
\end{array}$ & $\begin{array}{l}\text { 4. } 7 \\
\text { 5. } 4 \\
2.5\end{array}$ & $\begin{array}{l}\text { 6. } 6 \\
4.2 \\
1.0\end{array}$ & $\begin{array}{r}12.7 \\
12.8 \\
\quad 8.0\end{array}$ \\
\hline Total & 9.1 & 12. 6 & 11. 8 & 33.5 \\
\hline
\end{tabular}

1 For Floyd, Harlan, Knott, Letcher, and Pike Counties, includes remaining reserves estimated by the U.S. Bureau of Mines.

The reserves in eastern Kentucky are contained in 33 widespread coalbeds, but are largely concentrated in 7 main beds as follows:

\begin{tabular}{|c|c|}
\hline Bed & $\begin{array}{c}\text { Orioinal reserves } \\
\text { (billions of } \\
\text { short tons) }\end{array}$ \\
\hline Upper Elkhorn No. 3 & -1.9 \\
\hline Fire Clay & 4.2 \\
\hline Upper Elkhorn No. 1 & 2.7 \\
\hline Fire Clay Rider & 2.7 \\
\hline Amburgy & 2.3 \\
\hline Upper Elkhorn No. 2 & 2.2 \\
\hline Hazard No. 7 & 1.8 \\
\hline
\end{tabular}

More than half the total reserves of eastern Kentucky are contained in Pike, Harlan, Knott, Perry, and Floyd Counties.

Most of the total estimated reserves in eastern Kentucky are less than 1,000 feet below the surface and only a small fraction are between 1,000 and 2,000 feet.

\section{MARYLAND}

The remaining coal reserves in Maryland, as of January 1, 1950, are here estimated to total approximately 1.2 billion tons. This estimate is based in part on two reports by Toenges and others $(1949,1952)$ describing the results of recent investigations by the U.S. Bureau of Mines, the Maryland Department of Geology, Mines, and Water Resources, and the U.S. Geological Survey in three of the five coal fields in Maryland.

The first report (Toenges and others, 1949) pertains to the Georges Creek basin and the northern part of the Upper Potomac basin and the second to the Castleman basin. In the areas covered by the two reports, the estimated remaining reserves, as of the period January 1, 1947-50, total 859 million tons. The total estimated remaining reserves of the State are derived by extrapolation of this figure on the basis of the proportionate distribution of re- 
serves as calculated by Campbell in 1928. According to the earlier appraisal by Campbell, the proportionate distribution of reserves in the several coal basins in Maryland is as follows: Georges Creek, 50 percent; Upper Potomac, 20 percent; Castleman, 15 percent; Upper Youghiogheny, 5 percent; and Lower Youghiogheny, 10 percent. On this basis the total reserves in the Georges Creek, Upper Potomac, and Castleman basins constitute 85 percent of the total original coal reserves in the State. Approximately 16 percent of the total reserves of the State attributed to these 3 basins is outside the areas considered in the 1949 and 1952 estimates; therefore, the coal in the areas reexamined includes 69 percent of the total remaining coal reserves in Maryland. If Campbell's estimate of the distribution of reserves in Maryland is correct, and it can be assumed that 859 million tons is 69 percent of the total remaining reserves, then the remaining reserves, as of the period January 1 , 1947-50, total 1.2 billion tons. Based as it is upon a broad extrapolation of data from several sources, this figure is subject to modification as more information becomes available about Maryland coal reserves. It is, however, of the proper order of magnitude for comparison with other States where reestimates of reserves have been completed in recent years.

The coal-bearing rocks in Maryland cover an area of about 440 square miles in three parallel structural troughs that extend northeastward across Garrett and Allegany Counties in the western part of the State. The easternmost trough is divided by the Potomac and Savage Rivers into the Georges Creek basin to the north and the Upper Potomac basin to the south. The central trough is divided into the Castleman basin to the north and the Upper Youghiogheny basin to the south. The westernmost trough is known as the Lower Youghiogheny basin.

In 1949, Toenges and others estimated the remaining reserves in the Georges Creek basin and the northern half of the Upper Potomac basin, as of January 1, 1947, to total 627 million tons. The estimate includes reserves in 10 beds, 18 inches or more thick, lying below the Pittsburgh bed. The Pittsburgh bed and the overlying Sewickley bed have been mined extensively in the past and are now nearly depleted. The reserves are classified according to the measured, indicated, and inferred categories and according to four thickness categories. The coal is of low-volatile bituminous rank and is strongly coking.

In 1952, Toenges and others estimated the remaining reserves in the central part of the Castleman basin, as of January 1, 1950, to total 232 million tons. The estimate includes reserves in 6 beds, 14 inches or more thick. The reserves are classified according to 
the measured, indicated, and inferred categories, and according to three thickness categories. The coal is of low- to medium-volatile bituminous rank and in general is strongly coking.

The estimates in the two reports on the Maryland coal fields are conservative as shown by two lines of consideration. The detailed maps accompanying the reports show the conservative areal extent assumed for each coalbed, and the relatively large number of observations in drill holes and outcrops that entered into the determination of bed thickness. The minimum coalbed thickness of 18 inches used in the report on the Georges Creek and upper Potomac basins is also more conservative than the minimum of 14 inches used in the report on the Castleman basin and elsewhere. The selected provisional figure of 1.2 billion tons for the remaining reserves of Maryland as of January 1, 1950, thus seems to be reasonable.

\section{MICHIGAN}

As estimated by Cohee and others (1950), the original coal reserves of Michigan total 297 million tons, all of bituminous rank. This figure includes remaining reserves, as of Jan. 1, 1950, totaling 220 million tons, plus an estimate for coal mined and lost in mining to Jan. 1, 1950, totaling 77 million tons. The reserves remaining on Jan. 1, 1950, include 125 million tons of measured reserves, 29 million tons of indicated reserves, and 66 million tons of inferred reserves. The estimate of 77 million tons for coal mined and lost in mining to Jan. 1, 1950, includes the recorded production of 46 million tons, plus an allowance for coal lost in mining estimated to be equal to about 40 percent of the coal originally in the ground. To prepare the estimate, which gives the distribution of total reserves by counties and by townships, data were assembled from published and unpublished reports in the files of the Michigan Geological Survey Division, and more than 2,500 logs of coal test wells and several hundred sets of drill cuttings from exploratory wells for oil and gas were examined.

As the coal in Michigan occurs sporadially in isolated beds that vary greatly in thickness and that generally pinch out in relatively short distances, satisfactory estimates of extent and average thickness were possible only for relatively small areas. In preparing the estimate of Michigan coal reserves, therefore, only those areas having adequate test-hole information were considered, and no estimate was attempted for a large part of the Michigan coal basin where coal should be present but where specific information was lacking. The part of the coal basin for which the necessary information was available was confined to the Saginaw Valley, south and southeast 
of Saginaw Bay, and included 33 townships in Bay, Tuscola, Midland, Saginaw, Huron, Shiawassee, and Genesee Counties.

The measured coal reserves in Michigan were divided into the following categories according to the thickness, in inches, of the coalbeds: 14 to 28,28 to 42 , and $>42$.

The measured reserves were also divided into the following categories according to the thickness, in feet, of overburden: 50 to 100, 100 to 200,200 to 300,300 to 400 . No attempt was made to break down the indicated and inferred reserves into thickness and depth categories because of the small amount of information available on these reserves. The indicated and inferred reserves are contained in beds 14 inches or more thick, however, and are less than 400 feet below the surface.

In classifying the reserves according to the relative abundance and reliability of information, the usual U.S. Geological Survey standards were modified slightly to accord with the geologic nature of the coalbeds in Michigan. Measured reserves were defined as reserves blocked out by closely spaced drilling, and the outer limit of a block of measured reserves was drawn within a few hundred feet of the outermost points of positive information. This conservative assumption was necessary to define measured reserves in Michigan because of the known lack of continuity of the beds.

Indicated reserves were defined as reserves for which tonnage estimates were based primarily on thickness measurements in isolated drill holes. It was assumed that the thickness of coal observed in the drill holes was representative of an area covered by a circle having a radius of one-eighth mile with the drill hole as its center.

Inferred reserves were defined as reserves for which tonnage estimates were based on the isolated drill holes that were also used in computing indicated reserves. The general rule was to limit inferred reserves to the area lying outside the one-eighth-mile circle containing indicated reserves and inside a circle with a radius of one-fourth mile. In some areas, however, where drill holes were more than half a mile but less than 1 mile apart and where the evidence indicated that the coal was fairly persistent, some reserves were inferred to be present between the holes: In calculating the reserve figures, the coal in Michigan was assumed to weigh 1,800 tons per acre-foot.

The accompanying table shows the estimated remaining coal reserves of Michigan, as of Jan. 1, 1950, classified according to various reserve categories. 
Estimated remaining coal reserves of Michigan, January 1, 1950

[In millions of short tons]

\begin{tabular}{|c|c|c|c|c|c|}
\hline \multirow{2}{*}{ Overburden (feet) } & \multirow{2}{*}{$\begin{array}{l}\text { Thickness of bed } \\
\text { (inches) }\end{array}$} & \multicolumn{3}{|c|}{ Reserves } & \multirow{2}{*}{ Total } \\
\hline & & Measured & Indicated & Inferred & \\
\hline \multirow[t]{3}{*}{50 to $100 \ldots$} & \multirow{3}{*}{$\begin{array}{l}14 \text { to } 28 \\
28 \text { to } 42\end{array}>42$} & $\begin{array}{r}1 \\
13\end{array}$ & & $\cdots$ & \\
\hline & & 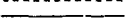 & $\cdots$ & $\cdots$ & 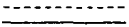 \\
\hline & & 14 & $\ldots$ & $\ldots$ & $\ldots \ldots$ \\
\hline 100 to 200 & $\left\{\begin{array}{l}14 \text { to } 28 \\
28 \text { to } 42 \\
>42\end{array}\right.$ & $\begin{array}{l}24 \\
64 \\
10\end{array}$ & (n) & $\cdots$ & \\
\hline \multirow{3}{*}{200 to $300 \ldots$} & \multirow{3}{*}{ 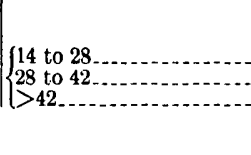 } & 88 & $\ldots$ & $\ldots$ & $-\ldots . .$. \\
\hline & & $\begin{array}{r}4 \\
214 \\
5\end{array}$ & (n) & 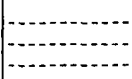 & \\
\hline & & 223 & - $\begin{array}{lll}-1 \\
-1\end{array}$ & $-\ldots \ldots$ & ….... \\
\hline Total_. & -..... & 125 & 329 & 366 & 220 \\
\hline
\end{tabular}

1 Includes 30 thousand tons with overburden ranging from 22 to $26 \mathrm{ft}$.

2 Includes 3 million tons with overburden ranging from 300 to $366 \mathrm{ft}$.

3 Estimate not classified by thickness of bed or amount of overburden.

\section{MISSOURI}

The original coal reserves of Missouri as estimated by Hinds (1913) total 79,362 million tons, all of 'bituminous rank. In Hinds' report the reserves are classified by counties, and for certain counties additional tables are presented to show reserves by coalbeds or by townships.

The estimate includes all coalbeds 14 inches or more thick and is based on an assumed weight of 1,800 tons per acre-foot for the coal. No attempt was made to classify the reserves according to thickness of beds or thickness of overburden.

Recent work by the Missouri Division of Geological Survey and Water Resources has shown that the Hinds' estimates are high in certain areas, and a reduction of the total is in prospect.

\section{MONTANA}

The original coal reserves of Montana total 222,047 million tons as estimated by Combo and others (1949). This estimate includes 2,363 million tons of bituminous coal, 132,151 million tons of subbituminous coal, and 87,533 million tons of lignite. The areal distribution of coal of various ranks in Montana is shown on a map by Combo and others (1950).

The Montana reserves were calculated and classified according to standard U.S. Geological Survey procedures and definitions with several minor exceptions as follows:

For bituminous coal the thickness categories used were 14 to 24 inches, 24 to 36 inches, and more than 36 inches, instead of the stand- 
Estimated original coal reserves of Montana

[In millions of short tons]

\begin{tabular}{|c|c|c|c|c|c|}
\hline \multirow{2}{*}{ Overburden (feet) } & \multirow[b]{2}{*}{$\begin{array}{l}\text { Thickness of bed } \\
\text { (inches) }\end{array}$} & \multicolumn{3}{|c|}{ Reserves } & \multirow[b]{2}{*}{ Total } \\
\hline & & $\begin{array}{c}\text { Measured } \\
\text { and } \\
\text { indicated }\end{array}$ & Inferred & $\begin{array}{l}\text { Unclassi- } \\
\text { fled }\end{array}$ & \\
\hline \multicolumn{6}{|c|}{ Bituminous coal } \\
\hline \multirow[t]{2}{*}{0 to $2,000 \ldots$} & \multirow[t]{2}{*}{$\begin{array}{l}14 \text { to } 24 \\
24 \text { to } 36 \ldots \\
>36\end{array}$} & $\begin{array}{r}279 \\
348 \\
1,036\end{array}$ & $\begin{array}{l}167 \\
144 \\
389\end{array}$ & 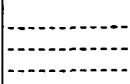 & $\begin{array}{r}446 \\
492 \\
1,425\end{array}$ \\
\hline & & 1,663 & 700 & & 2,363 \\
\hline \multicolumn{6}{|c|}{ Subbituminous coal } \\
\hline \multirow{3}{*}{0 to 2,000 .. } & Thickness (feet) & \multirow[b]{2}{*}{$\begin{array}{r}5,392 \\
15,486 \\
26,370\end{array}$} & \multirow[b]{2}{*}{$\begin{array}{r}2,326 \\
9,246 \\
15,975\end{array}$} & & \multirow[b]{2}{*}{$\begin{array}{r}7,718 \\
24,732 \\
42,345 \\
57,356\end{array}$} \\
\hline & 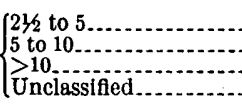 & & & (57,356. & \\
\hline & & 47,248 & 27,547 & 57,356 & 132,151 \\
\hline
\end{tabular}

\begin{tabular}{|c|c|c|c|c|c|}
\hline \multicolumn{6}{|c|}{ Lignite } \\
\hline \multirow{3}{*}{0 to $2,000 \ldots$} & Thickness (feet) & & & & \\
\hline & $\left\{\begin{array}{l}235 \text { to } 5 \\
5 \text { to } 10 \\
100 \\
\text { unclassifed........ }\end{array}\right.$ & $\begin{array}{r}4,876 \\
6,63 \\
2,566 \\
\cdots\end{array}$ & $\begin{array}{r}10,178 \\
13,136 \\
435 \\
\end{array}$ & 49,729 & $\begin{array}{r}15,054 \\
19,749 \\
3,001 \\
49,729\end{array}$ \\
\hline & & 14,055 & 23,749 & 49,729 & 87,533 \\
\hline Total, all ranks............ & (n) & 62,966 & 51,996 & 107,085 & 222,047 \\
\hline
\end{tabular}

ard categories of 14 to 28 inches, 28 to 42 inches, and more than 42 inches, which were established after the Montana work was underway. For subbituminous coal and lignite the standard categories of $2 \frac{1}{2}$ to 5 feet, 5 to 10 feet, and more than 10 feet were used.

The categories of measured and indicated reserves were combined in a single category termed "Measured and indicated" because only a very small part of Montana reserves could be classed as measured. All coal classed as "Measured and indicated" is less than 2 miles from the outcrop, and more than 50 percent is less than 1 mile. The standard category of inferred reserves includes most of the coal lying more than 2 miles from the outcrops.

The Montana estimate includes reserves only to a maximum depth of 2,000 feet below the surface and thus is more conservative than other State estimates, which generally include coal to a depth of 3,000 feet. No attempt was made to estimate reserves in inter- 
mediate categories, but about 75 percent of the total is less than 1,000 feet below the surface.

The Montana coal fields cover 35 percent of the total area of the State. Reserves are present in 35 out of 56 counties, but are concentrated largely in the Fort Union region and the Powder River Basin in the eastern part of the State. Big Horn, Powder River, and Rosebud Counties alone contain more than half the total in the State.

About 10 percent of the total area of coal-bearing rocks in Montana was not included in the estimate because no information was available on the thickness and extent of the beds. The areas omitted are concentrated, in general, in the northeastern, lignite-bearing part of the State, where the coal-bearing rocks are concealed by glacial drift. The estimated reserves of lignite should be increased in the future as more detailed work is carried on in these areas.

The accompanying table shows the estimated original coal reserves of Montana classified according to various reserve categories.

\section{NEW MEXICO}

The original coal reserves of New Mexico total 61,755 million tons as estimated by Read and others (1950). This figure includes 50,801 million tons of subbituminous coal, 10,948 million tons of bituminous coal, and 6 million tons of anthracite.

The reserves were calculated and classified according to standard U.S. Geological Survey procedures and definitions except that an additional category of reserves, termed "inferred by zone," was established to provide for reserves that could not be determined by conventional methods. In New Mexico the coalbeds commonly occur in zones as a series of lenticular deposits interbedded with other sedimentary rocks. Although individual coalbeds are limited in extent, the coal-bearing zones are very persistent and may cover large areas. In consequence, the usual methods of calculating reserves by beds would not yield the total quantity of coal known to be present in the interior parts of the San Juan Basin or in the Raton Mesa field. Therefore, the coal zones were subjected to further examination as zones instead of as individual beds. The methods used for coal-zone calculations were similar to those used for individual coalbeds, and the same minimum thicknesses for coal of different ranks and the same ranges of overburden thicknesses were established. Because of the different approach, the reserves thus calculated are carried under the separate heading, "Inferred by zone" in the report by Read and others (1950).

About 88 percent of the total reserves in New Mexico is concentrated in the San Juan Basin in the northwest corner of the State, and more than half is in San Juan County alone. About 8 percent 
Estimated original coal reserves of New Mexico

[In millions of short tons]

\begin{tabular}{|c|c|c|c|c|c|c|}
\hline \multirow{2}{*}{$\begin{array}{c}\text { Overburden } \\
\text { (feet) }\end{array}$} & \multirow{2}{*}{$\begin{array}{l}\text { Thickness of bed } \\
\text { (inches) }\end{array}$} & \multicolumn{4}{|c|}{ Reserves } & \multirow{2}{*}{ Total } \\
\hline & & Measured & Indicated & Inferred & $\begin{array}{c}\text { Inferred by } \\
\text { zones }\end{array}$ & \\
\hline \multicolumn{7}{|c|}{ Bituminous coal } \\
\hline \multirow[t]{2}{*}{0 to $1,000 \ldots$} & \multirow[t]{2}{*}{$\begin{array}{l}>14 \\
14 \text { to } 28 \\
28 \text { to } 42 \\
>42 \text { in }\end{array}$} & $\begin{array}{r}73 \\
152 \\
429 \\
\end{array}$ & $\begin{array}{l}359 \\
334 \\
612\end{array}$ & $\begin{array}{r}335 \\
27 \\
360\end{array}$ & \begin{tabular}{|r|} 
\\
2,378 \\
\hdashline \\
\hdashline \\
\hdashline
\end{tabular} & $\begin{array}{r}2,378 \\
767 \\
513 \\
1,401 \\
\end{array}$ \\
\hline & & 654 & 1,305 & 722 & 2,378 & 5,059 \\
\hline \multirow[t]{2}{*}{1,000 to $2,000 \ldots$} & \multirow[t]{2}{*}{$\begin{array}{l}>14 \\
14 \text { to } 28 \\
28 \text { to } 42 \\
>42\end{array}$} & (... & $\begin{array}{r}7 \\
39 \\
70\end{array}$ & $\begin{array}{l}694 \\
356 \\
715\end{array}$ & \begin{tabular}{|c|}
1,763 \\
\hdashline \\
\hdashline \\
\end{tabular} & $\begin{array}{r}1,763 \\
702 \\
395 \\
785\end{array}$ \\
\hline & & 1 & 116 & 1,765 & 1,763 & 3,645 \\
\hline \multirow[t]{2}{*}{2,000 to 3,000} & \multirow[t]{3}{*}{$\begin{array}{l}>14 \text { to } 28 \\
28 \text { to } 42 \ldots\end{array}$} & $\cdots$ & $\begin{array}{r}2 \\
1 \\
\end{array}$ & 25 & \begin{tabular}{|c|}
1,830 \\
\\
\hdashline \\
\end{tabular} & $\begin{array}{r}1,839 \\
27 \\
1 \\
377\end{array}$ \\
\hline & & - & 3 & 402 & 1,839 & 2,244 \\
\hline Total... & & 655 & 1,424 & 2,889 & 5,980 & . $\quad 10,948$ \\
\hline
\end{tabular}

Subbituminous coal

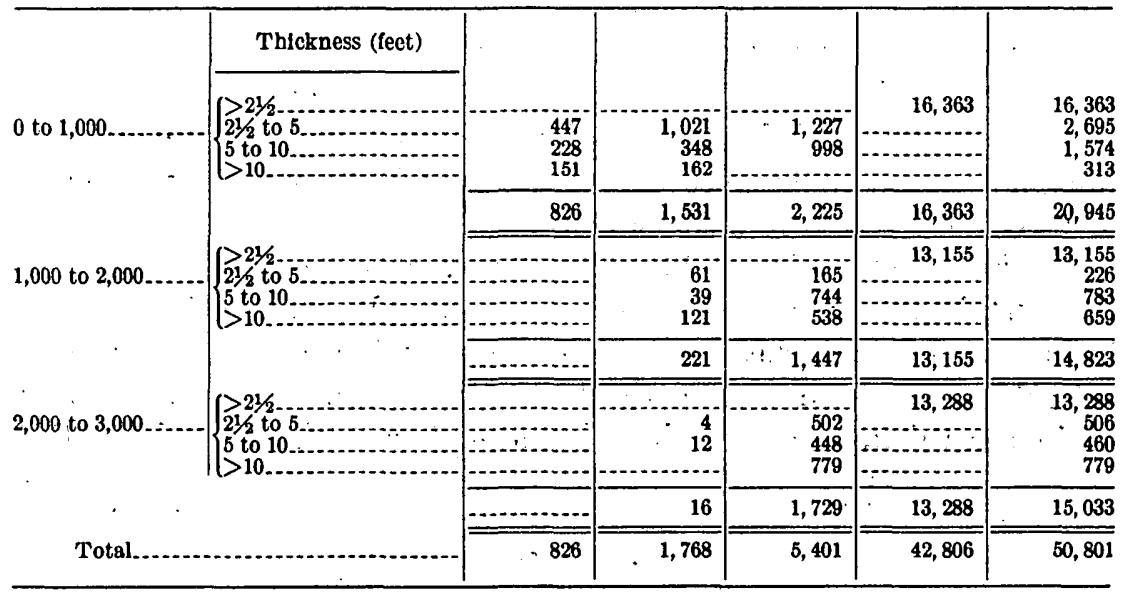

Anthracite

\begin{tabular}{|c|c|c|c|c|c|c|}
\hline \multirow{3}{*}{0 to $1,000 \ldots$} & Thickness (inches) & & & & & \\
\hline & \multirow[t]{3}{*}{$\begin{array}{l}>14 \\
28 \text { to } 28 \\
28\end{array}$} & $\begin{array}{l}1 \\
1 \\
1\end{array}$ & $\begin{array}{r}2 \\
1 \\
\end{array}$ & (1) & - & $\begin{array}{l}3 \\
2 \\
1\end{array}$ \\
\hline & & 3 & 3 & - & $\ldots \ldots \ldots \ldots$ & 6 \\
\hline Total... & & 3 & $\overline{3}$ & . & .............. & . \\
\hline \multicolumn{2}{|c|}{ Total, all ranks.. } & 1,484 & 3,195 & 8,290 & 48,786 & 61,755 \\
\hline
\end{tabular}


is in the Raton Mesa field in Colfax County, and the remainder is distributed among 7 small fields in the central part of the State.

The accompanying table gives the distribution of New Mexico reserves in various categories.

\section{NORTH CAROLINA}

All coal of commercial quality in North Carolina is contained in the Deep River field in Chatham, Lee, and Moore Counties. The original reserves of this field, as estimated by Reinemund (1955), total 112 million tons. This figure is a revision, based on additional data from mining and drilling, of an earlier estimate also prepared by Reinemund (1949). The estimate includes coal in the main bench of the Cumnock coalbed and in the Gulf coalbed; it does not include coal in the lower benches of the Cumnock bed, which, in general, are too high in ash, too thin, and too far below the main bed for profitable mining. Most of the coal is of bituminous rank, but the estimate includes small amounts of semianthracite and anthracite where the coal has been altered locally by igneous intrusions.

The North Carolina reserves were calculated and classified according to standard U.S. Geological Survey procedures and definitions with two-minor exceptions, as follows:

Only 2 overburden categories, 0 to 2,000 feet and 2,000 to 3,000 feet, were employed instead of the usual 3. The 0 - to 2,000-foot category was used because very little coal is present in the range of 0 to 1,000 feet below the surface.

Thickness categories of 14 to 28 inches, 28 to 36 inches, and more than 36 inches were employed instead of the standard 14 to 28 inches, 28 to 42 inches, and more than 42 inches, because a considerable amount of coal in the Deep River field is between 36 and 42 inches thick, and very little is more than 42 inches thick. For

Estimated original coal reserves in the Deep River feld, North Carolina 1

[In millions of short tons]

\begin{tabular}{|c|c|c|c|c|c|}
\hline \multirow{2}{*}{$\begin{array}{l}\text { Orerburden } \\
\text { (feet) }\end{array}$} & \multirow{2}{*}{$\begin{array}{l}\text { Thlokness of bed } \\
\text { (inches) }\end{array}$} & \multicolumn{3}{|c|}{ Reserves } & \multirow{2}{*}{ Totaj } \\
\hline & & Measured & Indicated & Inferred & \\
\hline \multirow{3}{*}{0 to $2,000 \ldots$} & \multirow{3}{*}{$\begin{array}{l}14 \text { to } 28 \ldots \ldots \ldots \ldots \ldots \\
28 \text { to } 36 \ldots \ldots \ldots\end{array}$} & 8 & 25 & 22 & 55 \\
\hline & & 21 & & - & $\begin{array}{l}13 \\
28\end{array}$ \\
\hline & & 38 & 36 & 22 & 96 \\
\hline \multirow[t]{2}{*}{2,000 to 3,000} & \multirow[t]{3}{*}{$\begin{array}{l}14 \text { to } 28 \\
28 \text { to } 36 \\
>36\end{array}$} & 1 & $\begin{array}{l}2 \\
5 \\
7 \\
\end{array}$ & …...... & \\
\hline & & 2 & 14 & . & 16 \\
\hline Total_.......... & & 40 & 50 & 22 & 112 \\
\hline
\end{tabular}

1 Mostly bituminous coal but includes small amounts of anthracite and semianthracite. 
this reason the selected categories will be more useful to those interested in the further development of the field.

The accompanying table shows the distribution of reserves in the Deep River field, N. C., in various categories.

\section{NORTH DAROTA}

As estimated by Brant (1953), the original reserves of lignite in North Dakota total 350,910 million tons, of which 9,522 million tons is classed as measured, 50,120 million tons as indicated, and 291,268 million tons as inferred.

The reserves are well distributed over an area of 28,000 square miles in 23 counties in the western half of the State. Of several counties with large reserves, Dunn County is conspicuous in containing 71 billion tons, or about one-fifth of the State total. This is also the record reserve tonnage for coal-bearing counties in the United States.

All the lignite included in the estimate is less than 1,200 feet below the surface, and for this reason no categories of overburden were established. Brant (1953, p. 4) estimates that about 70 percent of the total reserves is less than 500 feet below the surface; about 28 percent is 500 to 1,000 feet; and only about 2 percent is between 1,000 and 1,200 feet.

The information available in preparing this estimate was limited almost entirely to data obtained at the outcrops of the beds but was supplemented locally by a few drill logs. In many unmapped areas information was available only for the thickest or best known bed. Of the 28,000 -square-mile area considered to be underlain by lignite beds more than $21 / 2$ feet thick, about 1.7 percent was omitted for lack of information.

The North Dakota reserves were estimated according to the standard procedures of the U.S. Geological Survey as previously defined, and the results are tabulated in the Brant report by individual beds and townships, and by various reserve categories. A summary of this information is presented in the accompanying table.

Estimated original reserves of lignite in North Dakota ${ }^{2}$

[In millions of short tons]

\begin{tabular}{|c|c|c|c|c|}
\hline \multirow{2}{*}{$\begin{array}{c}\text { Thickness of bed } \\
\text { (feet) }\end{array}$} & \multicolumn{3}{|c|}{ Reserves } & \multirow{2}{*}{ Total } \\
\hline & Measured & Indicated & Inferred & \\
\hline \multirow{2}{*}{ 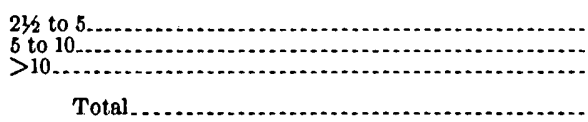 } & $\begin{array}{l}3,095 \\
3,964 \\
2,463\end{array}$ & $\begin{array}{l}20,095 \\
18,627 \\
11,398\end{array}$ & $\begin{array}{r}224,180 \\
36,938 \\
30,150\end{array}$ & $\begin{array}{r}247,370 \\
69,329 \\
44,011\end{array}$ \\
\hline & 9,522 & 50,120 & 291,268 & 350,910 \\
\hline
\end{tabular}

1 All beds are less than $1,200 \mathrm{ft}$ below the surface. 


\section{OHIO}

As recently estimated by the Ohio Division of Geological Survey (Brant and DeLong, 1960), the original coal reserves of Ohio total 46,488 million tons, all of which is of bituminous rank.

In the new estimate, which is based on procedures and definitions similar to those used by the U.S. Geological Survey, the reserves are divided into three categories, termed "proven," "probable," and "inferred." These are comparable to the categories "measured," "indicated," and "inferred" as used in this report. The reserves are further divided into 3 categories according to thickness, in inches, of the beds as follows: 14 to 28,28 to 54 , and $>54$.

The Ohio reserves are distributed among 32 counties and 24 coalbeds. Almost half the total is contained in Belmont, Carroll, Columbiana, Guernsey, Harrison, Jefferson, and Monroe Counties, and slightly more than half the total is contained in the Lower Kittanning, Middle Kittanning, and Pittsburgh beds.

Estimated original coal reserves of Ohio

[In millions of short tons]

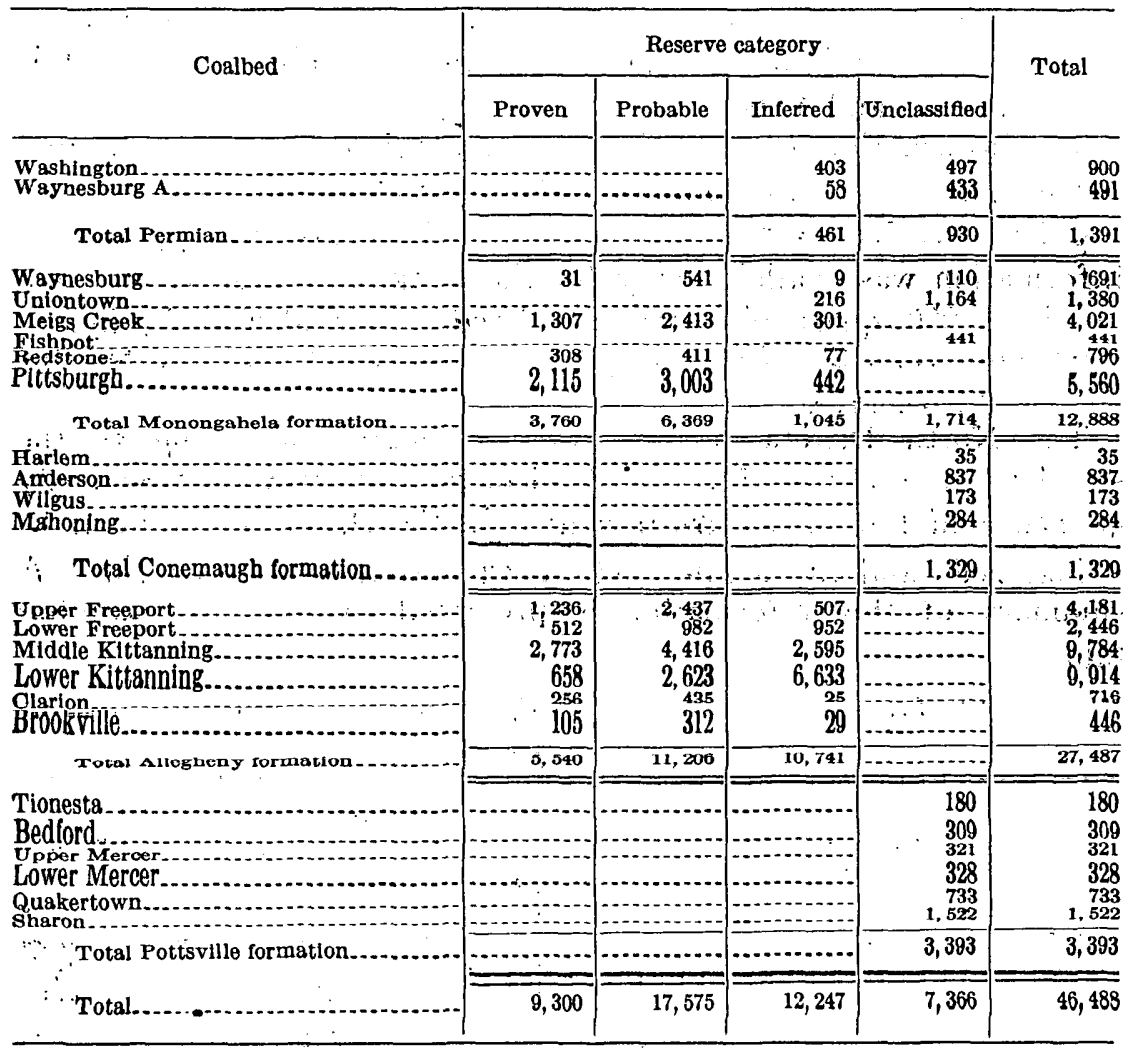


The accompanying table shows the distribution of Ohio reserves according to bed and according to the proven, probable, and inferred categories.

In addition to the Brant and DeLong report previously cited, much summary information about Ohio reserves is contained in earlier reports by Brant (1954, 1956), DeLong (1955, 1957), DeBrosse (1957), Granchi (1958), and Smith and others (1952).

\section{OKLAHOMA}

As estimated by Trumbull (1957), the original coal reserves of Oklahoma total 3,673 million tons, of which 3,245 million tons, or about 88 percent, remained in the ground on Jan. 1, 1953. The distribution of the remaining reserves, as of Jan. 1, 1953, in various categories is shown in the accompanying table.

Estimated remaining coal reserves of Oklahoma as of January 1,1959

[In millions of short tons]

\begin{tabular}{l|l|l|l|}
\hline Thickness of bed (inches) & \multicolumn{2}{|c|}{ Reserves } \\
\cline { 2 - 3 } & Measured & Indicated & Inferred \\
\hline
\end{tabular}

\begin{tabular}{|c|c|c|c|c|}
\hline \multicolumn{5}{|c|}{ High-volatile bituminous coal } \\
\hline $\begin{array}{l}14 \text { to } 28 \\
28 \text { to } 42 \\
>42\end{array}$ & $\begin{array}{r}66 \\
105 \\
130\end{array}$ & $\begin{array}{l}201 \\
456 \\
401 \\
\end{array}$ & $\begin{array}{r}353 \\
363 \\
38 \\
\end{array}$ & $\begin{array}{l}620 \\
924 \\
570\end{array}$ \\
\hline Total... & 301 & 1,058 & 755 & 2,114 \\
\hline
\end{tabular}

Medium-volatile bituminous coal

\begin{tabular}{|c|c|c|c|c|}
\hline $\begin{array}{l}14 \text { to } 28 \text { to } 42.0 \\
>42\end{array}$ & $\begin{array}{l}30 \\
13 \\
29\end{array}$ & $\begin{array}{r}70 \\
53 \\
56\end{array}$ & $\begin{array}{r}147 \\
32 \\
-\end{array}$ & $\begin{array}{r}247 \\
98 \\
85\end{array}$ \\
\hline Total & 72 & 179 & . $\quad 179$ & 430 \\
\hline
\end{tabular}

Low-volatile bituminous coal

\begin{tabular}{|c|c|c|c|c|}
\hline 14 to 28 to 42 & $\begin{array}{r}.30 \\
. \quad 70 \\
\cdot \quad 74 \\
\end{array}$ & $\begin{array}{r}148 \\
125 \\
93\end{array}$ & $\begin{array}{r}127 \\
34 \\
-1\end{array}$ & $\begin{array}{l}305 \\
229 \\
107\end{array}$ \\
\hline Total ................ & 174 & 366 & 161 & . . 701 \\
\hline Total, all ranks.... & 547 & 1,603 & 1,095 & 3,245 \\
\hline
\end{tabular}

The estimate was prepared according to standard U.S. Geological Survey procedures. It is based conservatively on existing mine, exploratory, and geologic information, and is markedly smaller than previous more generalized estimates. For this reason the estimate must be considered as a minimum that can be increased by future exploration and development. About 58 percent of the total estimated remaining reserves is less than 1,000 feet below 
the surface, 25 percent is 1,000 to 2,000 feet below the surface, and only 17 percent is 2,000 to 3,000 feet below the surface.

The reserves are distributed unequally among 25 named coalbeds, some of which may be correlatives. Most of the reserves are contained in the Lower and Upper Hartshorne, McAlester (Lehigh), and Henryetta beds, particularly in the Hartshorne beds, which are the most extensively mined.

About half of the reserves is concentrated in LeFlore and Pittsburgh Counties, and an additional third is concentrated in Latimer, Haskel, and Coal Counties.

Oklahoma coal increases markedly in rank from high-volatile bituminous in the western part of the field to low-volatile bituminous in the extreme eastern part of the field, thereby providing a wide range of useful properties. The estimated remaining reserves, as of Jan. 1, 1953, are distributed unequally among the three major ranks of coal as follows:

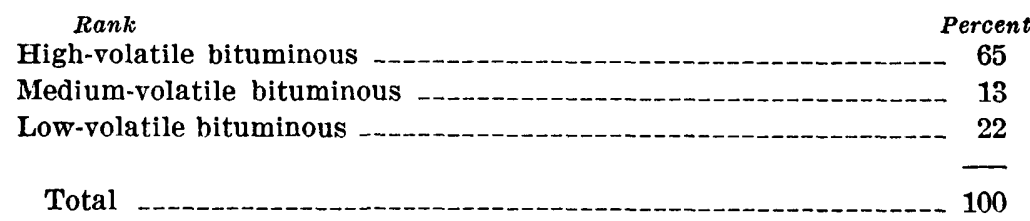

\section{OREGON}

As estimated by Mason and Erwin (1955), the original coal reserves of Oregon total 200 million tons, including about 180 million tons of subbituminous coal and about 20 million tons of bituminous coal. The subbituminous coal is contained largely in the Coos Bay field and the bituminous coal largely in the Eden Ridge field.

The estimate is based on previous estimates for small parts of the Coos Bay field prepared by Allen and Baldwin (1944), Duncan (1953), and Toenges and others (1948), which were extrapolated to cover the State as a whole. Because only a small part of the Coos Bay field has been mapped in detail, the State estimate could not be classified according to the usual reserve categories. However, much additional information about the distribution of reserves in the smaller areas is contained in the three reports cited above, and a good summary of the occurrence and distribution of coal in the State and a comprehensive bibliography are contained in the report by Mason and Erwin (1955).

\section{PENNSYLVANIA}

BTTUMTNOUS COAL

As estimated by Reese and Sisler (1928), the original bituminous coal reserves of Pennsylvania total 75,093 million tons. This esti- 
mate is the result of a careful, definitive study extending over several years. The Reese and Sisler report presents data on the area, thickness, and reserves of individual beds in individual townships, but does not provide a further breakdown into the typical reserve categories used in modern estimates.

The estimate can be shown to be conservative on two bases of comparison:

1. It includes coal having a minimum thickness of 18 inches, whereas most surrounding States employ a minimum of 14 inches.

2. An assumed specific gravity of 1.24 , or a weight of 1,688 tons per acre-foot, was used in calculating the reserves of all counties in Pennsylvania except Clarion and Jefferson Counties, for which a specific gravity of 1.34 , or a weight of 1,820 tons per acre-foot was used. The specific gravity of 1.34 not only represents the average weight of coal in these two counties as determined by a large number of tests, but is also more typical of bituminous coal generally. Had a specific gravity of 1.34 been used in the calculation for all counties, the estimated bituminous coal reserves of Pennsylvania would have been increased about 6 percent to a total of 80,545 million tons.

Several additional estimates of the coal reserves of small areas in Pennsylvania have been calculated and can be used as a partial check on the Reese and Sisler estimate for the entire State. These estimates are discussed in the following paragraphs.

The coal reserves of the adjoining Punxsutawney and Curwensville quadrangles were estimated independently by Ashley (1926, 1940). As Reese and Sisler reported reserves by counties and Ashley reported by quadrangles, Ashley's estimate for the two quadrangles cannot be compared directly with the estimate by Reese and Sisler. It is possible, however, to compare the two estimates for townships that lie entirely within the Punxsutawney and Curwensville quadrangles. For the 14 townships thus situated, Reese and Sisler estimated that the original coal reserves totaled 2,348 million tons, whereas Ashley estimated that the original coal reserves totaled 2,765 million tons. Ashley's estimate, therefore, is nearly 18 percent larger than the estimate of Reese and Sisler.

In calculating the reserves of the Curwensville quadrangle, Ashley included only coal having an average net thickness of at least 18 inches. In calculating the reserves of the Punxsutawney quadrangle, he included only coal having an average net thickness of at least 1 foot. Ashley defined the net thickness of the coal bed asthe thickness left after rejecting any minor benches separated from the main bench by a parting of greater thickness than the coal bench. In the case of 
a parting thinner than the coal bench, only the difference in thickness between the minor bench and the parting was added to the thickness of the major bench.

For both quadrangles, Ashley assumed the coal to weigh 1,800 tons per acre-foot.

The coal reserves of the Smicksburg quadrangle were estimated by Shaffner (1946), but again a comparison with the Reese and Sisler estimate can be made only for the townships lying completely within the quadrangle. For six townships, therefore, Shaffner estimated that the original coal reserves totaled 526 million tons, and Reese and Sisler estimated that the original reserves total 931 million tons. Shaffner's estimate is only 56 percent of that made by Reese and Sisler.

Much of the difference between these two estimates is probably accounted for, however, by the fact that Shaffner determined the thickness of the coal beds used in his calculations by the modulus of irregularity. As already discussed (p. 19), this formula results in a figure for the thickness of the coal that is less than the average thickness, and an estimate based on the use of the formula tends to be extremely conservative.

Shaffner assumed a specific gravity of 1.35 , or a weight of 1,840 tons per acre-foot, for the coal in the Smicksburg quadrangle.

Moyer estimated that the original coal reserves of Fayette County, Pa., totaled 7,570 million tons (Hickok and Moyer, 1940). For the same area Reese and Sisler estimated that the original coal reserves totaled 5,230 million tons. Moyer's estimate represents an increase of 45 percent over the estimate of Reese and Sisler.

Moyer assumed a specific gravity of 1.37 , or a weight of 1,860 tons per acre-foot, for the coal and included only beds having an average minable thickness of at least 26 inches. The minable thickness of a coalbed, as defined by Moyer, is the thickness of the coal remaining after subtracting partings, bone, and bony coal from the total thickness of the bed. Thin benches separated by a thick parting from the principal bench of a coalbed were also excluded in considering minable thickness.

The reserves in 12 counties in the bituminous coal field of Pennsylvania have been estimated by the U.S. Bureau of Mines as part of a program to investigate known minable reserves of coking coal (Dowd and others, 1950-52; Wallace and others, 1953-55; Blaylock and others, 1955-56). These estimates are for remaining measured and indicated reserves as of 1948 to 1952. They include coal to a minimum thickness of 14 inches and use an assumed weight of 1,800 tons per acre-foot.

The reserves as estimated by the Bureau of Mines are considerably less than those estimated by Reese and Sisler. The apparent de- 
crease is due mostly to the fact that the Bureau of Mines estimates include only measured and indicated reserves in relatively small areas, whereas Reese and Sisler include all classes of reserves in a relatively larger area. Considering the different standards applied and the different purposes for which they were intended, the Bureau of Mines estimates and the Reese and Sisler estimate are more or less compatible.

Although none of the more recent reserve estimates just discussed can be compared directly with the older Reese and Sisler estimate because of the different standards applied, particularly for minimum thickness of coalbeds and weight of coal, they show the conservativeness of the older estimate. Ashley (1944) recognized the conservative nature of the Reese and Sisler estimate and, on the basis of some of the later estimates just described, arbitrarily increased the Reese and Sisler figures of original coal reserves 10 percent for every county in Pennsylvania except Fayette County, for which he used the estimate by Moyer.

Use of the smaller estimate of Reese and Sisler has been continued in this summary report in preference to the larger Ashley estimate, because the Reese and Sisler estimate is based on a uniform, statewide study and is carefully documented, whereas the Ashley estimate is merely an undocumented 10 percent enlargement of the Reese and Sisler estimate. Also, the Reese and Sisler estimate is demonstrably conservative and, therefore, conforms with the modern trend in preparing coal reserve estimates.

\section{ANTHRACITE}

The original reserves of anthracite in Pennsylvania total 22,805 million tons, according to an estimate by Ashley (1945). This estimate was based directly upon a previous estimate by Ashmead (1926), with the exception of figures for Dauphin and Lebanon Counties, which Ashley decreased on the basis of later mining reports.

Ashmead based his reserve estimate on careful measurements of coalbed areas as shown on mine maps, but he listed no standards for the thickness or weight of the coal included. Presumably, therefore, in computing the anthracite reserves of Pennsylvania, Ashmead, and subsequently Ashley, accepted the same limits of thickness and the same figures of specific gravity that were adopted originally by Smith (1893), who made the first careful estimate of the anthracite reserves. (See also Lesley and others, 1895).

The minimum thickness of coal included in Smith's estimate was $21 / 2$ feet for the northern anthracite field and 2 feet for the other fields.

$586968-61-6$ 
In calculating anthracite reserves, Smith used different values, as determined by many tests, for the specific gravity of the coal in different parts of the anthracite fields. The coal in the Eastern Middle field, Western Middle field, and part of the Southern field was assigned a specific gravity of 1.61 , or a weight of 2,190 tons per acre-foot. The remainder of the coal in the Southern field was assigned a specific gravity of 1.5, or a weight of 2,040 tons per acre-foot, and the coal in the Northern field was assigned a specific gravity of 1.55 , or a weight of 2,110 tons per acre-foot. Smith estimated that the original reserves of anthracite in Pennsylvania totaled 21,849 million tons.

None of the estimators attempted a breakdown of Pennsylvania anthracite reserves into the categories employed in modern estimates.

Recent detailed geologic mapping by the U.S. Geological Survey in the anthracite fields has revealed much new information on thickness and correlation of beds and on structure, which will be useful when new estimates of Pennsylvania anthracite reserves are prepared.

\section{SOUTH DAKOTA}

As estimated by D.M. Brown (1952), the original lignite reserves of South Dakota total 2,033 million tons, all of which is less than 1,000 feet below the surface. In addition, the State contains 10,900 tons of bituminous coal, but this amount is too small to show in the accompanying table. The reserves were calculated and tabulated according to standard U.S. Geological Survey procedures and definitions.

As recorded in the report by Brown, the lignite reserves are concentrated in six counties in the northwestern part of the State. Hading County contains nearly 84 percent of the estimated reserves, but most of past production has been obtained from Dewey and Perkins Counties.

The accompanying table shows the estimated original reserves of lignite in South Dakota classified by thickness of bed and by the measured, indicated, and inferred categories.

Estimated original reserves of lignite of South Dakota

[In millions of short tons]

\begin{tabular}{|c|c|c|c|c|}
\hline \multirow{2}{*}{ Thickness of bed (feet) } & \multicolumn{3}{|c|}{ Reserves } & \multirow{2}{*}{ Total } \\
\hline & Measured & Indicated & Inferred & \\
\hline $\begin{array}{l}236 \text { to } 5 \\
5 \text { to } 10\end{array}$ & $\begin{array}{r}104 \\
34\end{array}$ & $\begin{array}{r}993 \\
673 \\
52\end{array}$ & (1) ${ }^{177}$ & $\begin{array}{r}1,274 \\
707 \\
52\end{array}$ \\
\hline Total... & 138 & 1,718 & 177 & 2,033 \\
\hline
\end{tabular}

160 thousand tons not included in total. 
As noted in the table, a large percentage of the South Dakota lignite reserves is contained in thin beds. Of the total estimated tonnage, 63 percent is in beds ranging from $21 / 2$ to 5 feet in thickness, 34 percent in beds 5 to 10 feet thick, and only 3 percent in beds more than 10 feet thick. This is in marked contrast to the distribution of reserves in States to the north and west where a large percentage of the total reserves is in thicker beds.

The table also shows the large concentration of reserves in the indicated category. Of the total reserves, 84 percent is classified as indicated, whereas only 7 percent is classified as measured and only 9 percent as inferred. This disparity results because the South Dakota lignite beds are lenticular, and points of observation are widely spaced and confined largely to measurements along the outcrops.

\section{TENNESSEE}

As recently estimated by Luther (1959), the coal reserves remaining in the ground in Tennessee on Jan. 1, 1959, total 1,192 million tons, all of which is of bituminous rank. This new estimate is based, in part, on summary studies of measured and indicated reserves in 14 counties in Tennessee prepared by the U.S. Bureau of Mines (Williams and others, 1954, 1955, 1956; Hershey and others, 1956; Lowe and others, 1956) and in part on recent geologic mapping carried out by the Tennessee Division of Geology.

The reserves are divided into the three standard categories, measured, indicated, and inferred, according to the relative abundance of reliable information, and into two standard thickness categories, 28 to 42 inches and more than 42 inches. Because the estimate omits coal in beds less than 28 inches thick, it is markedly more conservative than estimates of surrounding States, which include beds to a minimum thickness of 14 inches.

Most of the reserves are concentrated in the northern part of the Tennessee coal field. Campbell County contains the largest reserves, followed in order by Anderson, Morgan, Scott, and Claiborne Counties. The reserves are divided unequally among 27 named beds, of which 5 contain more than 60 percent of the total tonnage. These

Remaining coal reserves of Tennessee as of January 1, 1959

[In millions of short tons]

\begin{tabular}{|c|c|c|c|c|}
\hline \multirow{2}{*}{ Thlckness of bed (inches) } & \multicolumn{3}{|c|}{ Reserves } & \multirow{2}{*}{ Total } \\
\hline & Measured & Indicated & Inferred & \\
\hline $\begin{array}{r}28 \text { to } 42 \\
>42\end{array}$ & $\begin{array}{l}314 \\
132\end{array}$ & $\begin{array}{l}468 \\
148\end{array}$ & $\begin{array}{l}649 \\
201\end{array}$ & $\begin{array}{r}1,431 \\
481\end{array}$ \\
\hline Total.. & 446 & 616 & 850 & 1,912 \\
\hline
\end{tabular}


five beds, listed in order of reserve tonnage, are the Sewanee, Coal Creek, Wilder, Big Mary, and Poplar Creek.

The accompanying table gives the distribution of Tennessee reserves according to thickness of beds and relative abundance of reliable information.

TEXAS

\section{BITUMINOUS COAT}

As estimated by Campbell (1929), the original reserves of bituminous coal in Texas total 8,000 million tons. The experience accumulated over the years since the estimate was prepared has demonstrated that it is too large, perhaps several times too large. As of the present time, however, it has not been possible to revise this estimate, and as an unsubstantiated change would be undesirable, the older figure has been retained in tables 1 and 2 .

\section{LIGNITE}

As estimated by Perkins and Lonsdale (1955), the original lignite reserves in Texas total 7,070 million tons. This estimate is based on several conservative assumptions and may be considered an irreducible minimum. The estimate includes only lignite in beds 5 feet or more thick. It includes only lignite less than 500 feet below the surface divided into 2 categories, 0 to 90 feet, and 90 to 500 feet. It includes only measured and indicated reserves calculated according to the following assumptions:

1. A known occurrence of lignite in a drill hole, at an outcrop, or other point, establishes an area of measured reserves in a circle of 1/4-mile radius drawn around the point, and an area of indicated reserves between the first circle and a second circle of $1 / 2$-mile radius drawn around the same point.

2. The specific gravity of lignite was assumed to be 1.2 , or about 1,640 tons per acre-foot.

The accompanying table, abstracted from the Perkins and Lonsdale report, shows the distribution of Texas lignite reserves in the several categories as defined.

Estimated original lignite reserves of Texas in beds 5 feet or more thick and less than 500 feet below the surface

[In millions of short tons]

\begin{tabular}{r|r|r|r}
\hline \multirow{2}{*}{ Overburden (feet) } & \multicolumn{2}{|c|}{ Reserves } & \multirow{2}{*}{ Total } \\
\cline { 2 - 3 } & \multicolumn{1}{|c|}{ Measured } & \multicolumn{1}{c|}{ Indicated } & \\
\hline $\begin{array}{r}0 \text { to } 90 \\
90 \text { to } 5000\end{array}$ & $\begin{array}{r}1,027 \\
859\end{array}$ & $\begin{array}{r}2,255 \\
2,929\end{array}$ & $\begin{array}{r}3,282 \\
3,788\end{array}$ \\
\hline Total & 1,886 & 5,184 & 7,070 \\
\hline
\end{tabular}




\section{UTAF}

The original coal reserves of Utah are here estimated to be 28,378 million tons, including 28,222 million tons of bituminous coal and 156 million tons of subbituminous coal. This estimate is a summation of 12 estimates of reserves in individual fields. Of these 12 estimates, 9 are contained in previous publications of the Geological Survey, and 3 were prepared by the writer and associates for use in this summary. The accompanying table shows the amount and source of each individual estimate.

\section{Estimated original coal reserves of Utah}

[In millions of short tons]

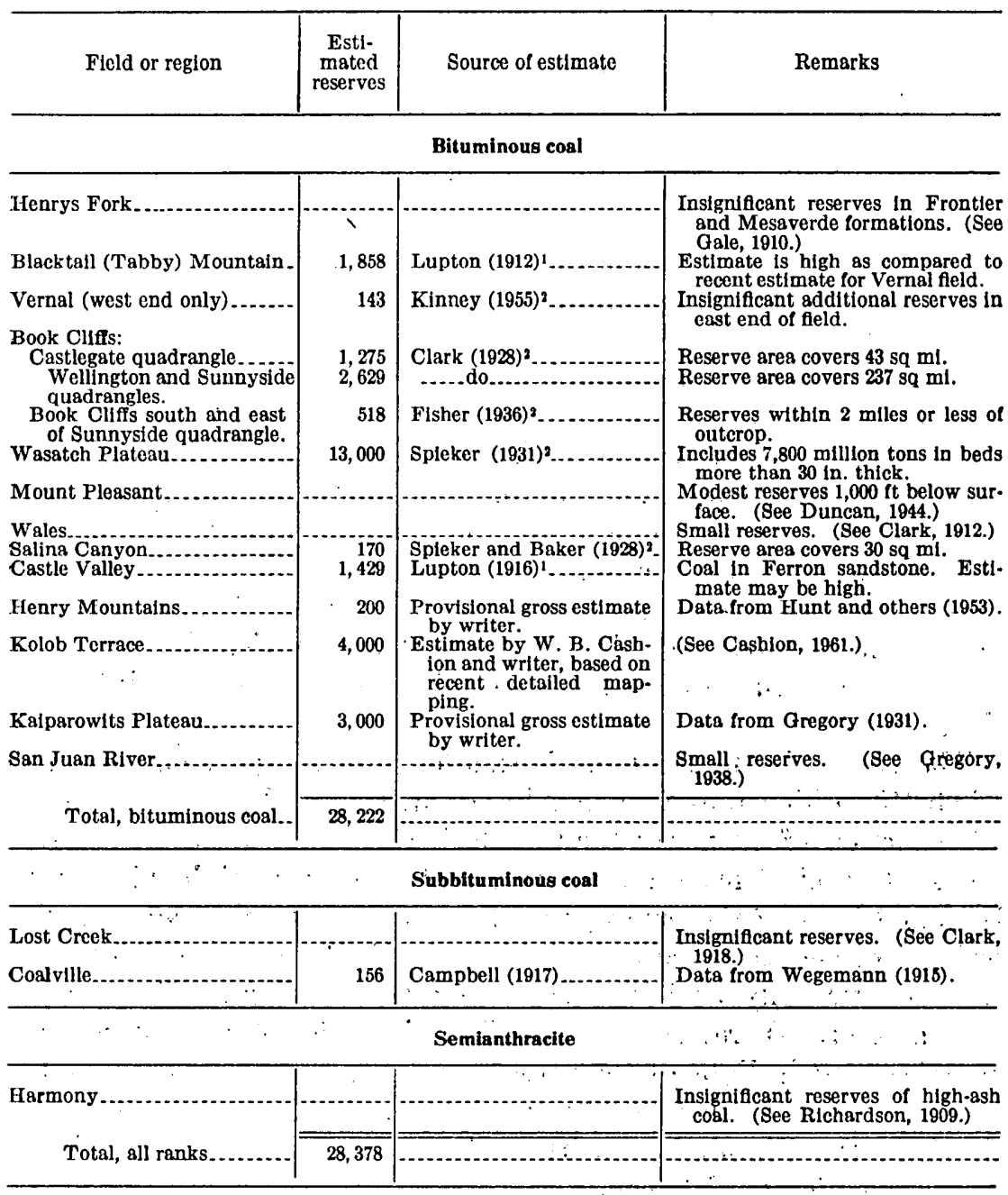

1 Report contains breakdown of reserves by townships only.

Report contalns breakdown of reserves by beds and by townships. 
In eight of the areas summarized in the table, the estimates are based on detailed information on reserves. in individual beds and townships or in individual townships. Additional information on the distribution of reserves is contained in the publications cited in the table. Other published reports contain information about the local occurrence and thickness of coal, which has been used to prepare the provisional estimates or the conclusions here presented. For the Kaiparowits Plateau, which is the most remote and least explored of the major coal-bearing areas in Utah, the estimate is based in small part on measurements of coal thickness and in large part on general considerations of the thickness and nature of the coal-bearing rocks, and for this reason no detailed breakdown of the reserves is possible.

The nine previously published estimates that make up the greater part of the total shown in the table were prepared by various individuals during the period from 1912 to the present and, as a result, show some individual variation. Following a pattern that has been characteristic of coal reserve estimates over the years, the older estimates tend to be larger than recent estimates. This is particularly well illustrated by the difference between the comparatively large Lupton estimate of 1912 for the Blacktail (Tabby) Mountain field and the comparatively small Kinney estimate of 1955 for the nearby Vernal field. The two fields are about the same size, and the coal is contained in rocks of the same age. On this basis of analysis, the Lupton estimate of 1916 for the Castle Valley field may also be high as compared to the author's present estimate for the nearby Henry Mountains field.

In spite of these discrepancies, the total obtained by adding all documented figures, regardless of date of preparation, indicates the order of magnitude of reserves determinable from existing information.

The new estimate for Utah is smaller than the previous estimate of 93,340 million tons prepared by $\mathbf{M}$. R. Campbell, largely because of reduction of estimates for the Book Cliffs and Wasatch Plateau fields. Campbell made allowance for all coal that might ultimately be found back of the outcrops in these two great fields, whereas the writers whose more recent estimates are cited for these fields took into account only coal in a zone near the outcrops. The smaller estimates are, therefore, more realistic in light of present mining practices and in light of the present and near future needs for coal, but it is certain that larger tonnages are potentially present at depth in the Uintah Basin, back of the Book Cliffs, and at depth under the Wasatch Plateau. 


\section{VIRGINIA}

As estimated by Andrew Brown and others (1952), the original coal reserves of Virginia total 12,051 million tons, of which 932 million tons had been mined and lost in mining to Jan. 1, 1951, and 11,119 million tons remained in the ground.

The accompanying table, taken from Brown and others (1952), shows the distribution of the total remaining reserves of bituminous coal, as of Jan. 1, 1951, and the original reserves of semianthracite in various reserve categories according to the standard definitions employed by the U.S. Geological Survey. Noteworthy is the fact that most of the reserves included in the estimate are less than 1,000 feet below the surface.

Of the total amount of coal included in the estimate, 97 percent is concentrated in 7 counties in the bituminous coal area of southwestern Virginia. Buchanan County in the corner between West Virginia and Kentucky contains about one-third of the total reserves. The reserves are contained in 60 named coalbeds, of which the Kennedy, Jawbone, Raven, and Splash Dam each contains more than 1 billion tons.

Only 3 percent of the total remaining reserves is contained in fields in the Appalachian Valley where the coal is semianthracite.

Estimated remaining coal reserves of Virginia, January 1, 1951

[In millions of short tons]

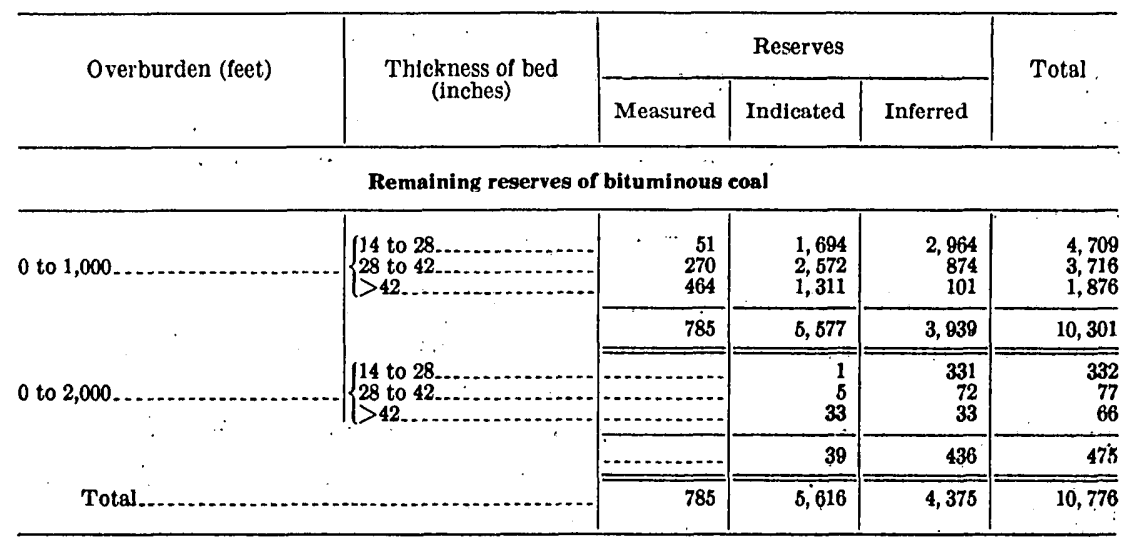

Original reserves of eemianthracite

\begin{tabular}{|c|c|c|c|c|}
\hline 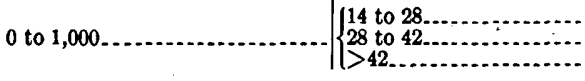 & 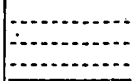 & $\begin{array}{r}31 \\
11 \\
126\end{array}$ & $\begin{array}{r}24 \\
18 \\
145\end{array}$ & $\begin{array}{r}55 \\
29 \\
271\end{array}$ \\
\hline $\begin{array}{l}\text { Total } \\
\text { Mined and lost in mining }\end{array}$ & & 168 & 187 & $\begin{array}{r}355 \\
12\end{array}$ \\
\hline Total, remaining reserves of semianthracite... & & & & 343 \\
\hline Total, remalning reserves, all ranks... & & & & 11,118 \\
\hline
\end{tabular}


No estimates were made for the coal of Triassic age in the Richmond and Farmville basins, because the information available was insufficient.

\section{WASHINGTON}

Campbell (1929) has estimated that the original coal reserves of Washington total 63,878 million tons, including 11,413 million tons of bituminous coal, 52,442 million tons of subbituminous coal plus a small amount of lignite, and 23 million tons of anthracite. This estimate is intended to include all classes of reserves to a depth of 3,000 feet in beds to a minimum thickness of 14 inches for bituminous coal and anthracite and to a minimum of 30 inches for subbituminous coal and lignite. Persons familiar with the geology and past coal mining operations in Washington feel that the Campbell estimate is high as compared to recent estimates for other States, but its use has been continued in this report because a new estimate is not yet available, and because an undocumented change at this time would be valueless and unnecessarily confusing.

For the past several years the U.S. Geological Survey has been engaged in detailed geologic mapping of selected coal-bearing areas in Washington in order to provide data helpful in the ultimate development of those areas and also to contribute to an improved analysis of the overall distribution of coal in the State. The results of this work have appeared in reports by Warren and others (1945), Snavely and others $(1951,1958)$, and Roberts (1958).

The U.S. Geological Survey, in cooperation with the Washington Department of Conservation, Division of Mines and Geology, is currently engaged in a stepped-up program of investigation of Washington coal. This program will include a new estimate of coal reserves.

\section{WEST VIRGINIA}

The original coal reserves of West Virginia total 116,618 million tons according to an estimate by Headlee and Nolting (1940). This figure is the sum of the original reserves in 44 coal-bearing counties as estimated in numerous county reports published by the West Virginia Geological Survey in the period from about 1906 to 1939. The Headlee and Nolting summary report includes tables showing the distribution of reserves by minable coal beds as well as by counties, and the county reports contain additional details.

The Headlee and Nolting estimate includes reserves in a few beds averaging 1 foot in thickness, but the amount of such coal is small. Price and others (1938) state that about 75,500 million tons of coal in West Virginia is contained in beds averaging 3 feet or more in thickness. The remainder of the original reserves, or about 41,000 million tons, is contained in thinner beds. 
In computing the reserves of West Virginia, the coal was assumed to have a specific gravity of 1.28 , or a weight of 1,742 tons per acre-foot, which is somewhat low for bituminous coal in the ground.

In the period from 1951 to 1956 the U.S. Bureau of Mines published reports on reserves in 11 counties in West Virginia as part of a program to investigate minable reserves of coking coal. (See Dowd and others, 1952-56; Provost and others, 1956; Tavenner and others, 1950; Travis and others, 1956; Wallace and others, 1952-54.) These county estimates include only measured and indicated reserves and thus are not strictly comparable with the county estimates of Headlee and Nolting, which include inferred reserves in the totals. However, the Bureau of Mines reports contain much useful information about the distribution of readily available reserves, and should be consulted in conjunction with the Headlee and Nolting report and with the county reports of the West Virginia Geological Survey.

\section{WYOMING}

As estimated by Berryhill and others (1950), the original coal reserves of Wyoming total 121,554 million tons, of which 13,235 million tons is bituminous coal, and 108,319 million tons is subbituminous coal. According to a few available analyses, a large tonnage of coal on the eastern side of the Powder River Basin is near the dividing line between lignite and subbituminous coal but for convenience is included in this estimate with reserves of subbituminous coal. The areal distribution of coal in Wyoming is shown on a map by Berryhill and others (1951), which is complementary to the reserve report.

The Wyoming estimate was prepared and classified according to standard U.S. Geological Survey procedures and definitions. It presents data on reserves in various categories according to counties, townships, rank, thickness of beds, and thickness of overburden, but not according to individual beds. A summary of the estimate is given in the accompanying table.

Approximately 53 percent of the total area of coal-bearing rocks in Wyoming was not included in the estimate because little or no information was available on the coalbeds. The estimate of reserves in Wyoming should, therefore, be substantially increased as mapping and exploration continue.

The Wyoming coal reserves are distributed among 9 major structural basins or regions covering all or parts of 20 counties. The large Powder River Basin contains 78 percent of the total estimated reserves, and Campbell County, which lies entirely in the Powder River Basin, contains 51 percent of the total. With more than 62 billion tons of reserves, Campbell County contains the second largest reserve tonnage of any county in the United States, exceeded only 
by Dunn County, N. Dak. A large proportion of the reserves in Campbell County is concentrated in the very thick Roland and Smith beds, which locally attain maximum thicknesses of 106 and 38 feet, respectively. Because of these 2 beds, a number of townships in eastern Campbell County individually contain more than 1 billion tons of original reserves, and 1 township, T. 50 N., R. 72 W., contains 2,871 million tons, which is the record original reserve tonnage for townships in the United States.

\section{Estimated original coal reserves of Wyoming}

[In millions of short tons]

\begin{tabular}{|c|c|c|c|c|c|}
\hline \multirow{2}{*}{ Overburden (feet) } & \multirow{2}{*}{$\begin{array}{l}\text { Thickness of bed } \\
\text { (inches) }\end{array}$} & \multicolumn{3}{|c|}{ Reserves } & \multirow{2}{*}{ Total } \\
\hline & & Measured & Indicated & Inferred & \\
\hline \multicolumn{6}{|c|}{ Bituminous coal } \\
\hline \multirow[t]{2}{*}{0 to 1,000} & \multirow[t]{2}{*}{$\begin{array}{r}14 \text { to } 28 \\
28 \text { to } 42\end{array}$} & $\begin{array}{r}24 \\
150 \\
1,513\end{array}$ & $\begin{array}{r}446 \\
681 \\
2,181\end{array}$ & $\begin{array}{r}57 \\
83 \\
593\end{array}$ & $\begin{array}{r}527 \\
914 \\
4,287\end{array}$ \\
\hline & & 1,687 & 3,308 & 733 & 5,728 \\
\hline \multirow[t]{2}{*}{1,000 to 2,000} & \multirow[t]{2}{*}{$\begin{array}{l}14 \text { to } 28 \\
28 \text { to } 42\end{array}$} & $\begin{array}{r}5 \\
22 \\
319\end{array}$ & $\begin{array}{r}144 \\
332 \\
1,507\end{array}$ & $\begin{array}{l}276 \\
426 \\
967\end{array}$ & $\begin{array}{r}425 \\
780 \\
2,793\end{array}$ \\
\hline & & 346 & 1,983 & 1,669 & 3,998 \\
\hline \multirow[t]{2}{*}{2,000 to $3,000 \ldots$} & \multirow[t]{2}{*}{$\begin{array}{l}14 \text { to } 28 \\
28 \text { to } 42\end{array}$} & 30 & $\begin{array}{r}59 \\
98 \\
1,043\end{array}$ & $\begin{array}{r}294 \\
449 \\
1,536\end{array}$ & $\begin{array}{r}353 \\
547 \\
2,609\end{array}$ \\
\hline & & 30 & 1,200 & 2,279 & 3,509 \\
\hline \multicolumn{2}{|c|}{ Total } & 2,063 & 6,491 & 4,681 & 13,235 \\
\hline
\end{tabular}

Subbituminous coal

\begin{tabular}{|c|c|c|c|c|c|}
\hline \multirow{3}{*}{0 to $1,000 \ldots \ldots$} & Thickness (feet) & \multirow[b]{2}{*}{$\begin{array}{r}8 \\
71 \\
1,473\end{array}$} & \multirow[b]{2}{*}{$\begin{array}{r}6,504 \\
9,151 \\
15,562\end{array}$} & \multirow[b]{2}{*}{$\begin{array}{r}7,359 \\
15,429 \\
35,148\end{array}$} & \multirow[b]{2}{*}{$\begin{array}{l}13,871 \\
24,651 \\
52,183\end{array}$} \\
\hline & $\left\{\begin{array}{l}21 / 2 \text { to } 5 \ldots \ldots \ldots \\
5 \text { to } 10 \ldots \ldots \ldots \ldots\end{array}\right.$ & & & & \\
\hline & . & 1,552 & 31,217 & 57,936 & 90,705 \\
\hline \multirow[t]{2}{*}{1,000 to 2,000} & \multirow[t]{2}{*}{$\begin{array}{l}21 / 2 \text { to } 5 \\
5 \text { to } 10\end{array}$} & $\begin{array}{r}5 \\
2 \\
2\end{array}$ & $\begin{array}{l}738 \\
673 \\
364\end{array}$ & $\begin{array}{r}2,871 \\
9,499 \\
498\end{array}$ & $\begin{array}{r}3,609 \\
10,177 \\
864\end{array}$ \\
\hline & & 7 & 1,775 & 12,868 & 14,650 \\
\hline \multirow[t]{2}{*}{2,000 to 3,000} & \multirow[t]{2}{*}{$\begin{array}{l}21 / 2 \text { to } 5 \\
5 \text { to } 10\end{array}$} & 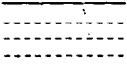 & $\begin{array}{l}281 \\
286 \\
172\end{array}$ & $\begin{array}{r}810 \\
1,216 \\
219\end{array}$ & $\begin{array}{r}1.092 \\
1,482 \\
390\end{array}$ \\
\hline & & $\ldots$ & 719 & 2,245 & 2,964 \\
\hline $\begin{array}{c}x_{1} \\
\cdots\end{array}$ & $\therefore$ & 1,559 & 33,711 & 73,049 & 108,319 \\
\hline Total, both ranks..... & & 3,622 & 40,202 & 77,730 & 121,854 \\
\hline
\end{tabular}

\section{OTHER STATES}

The reserves of Arizona, California, Idaho, Louisiana, Nebraska, and Nevada are included under the heading "Other States." In 
each of these States the reserves are either small or information about the occurrence and distribution of coal is so scanty that preparation of a meaningful estimate is impossible.

The accompanying table gives the estimated reserves and source of the estimate used for each State. The individual figures, however, have a very low order of accuracy and are presented only to show how the totals by rank were obtained.

Estimated original coal reserves of Arizona, California, Idaho, Louisiana, Nebraska, and Nevada

[In millions of short tons]

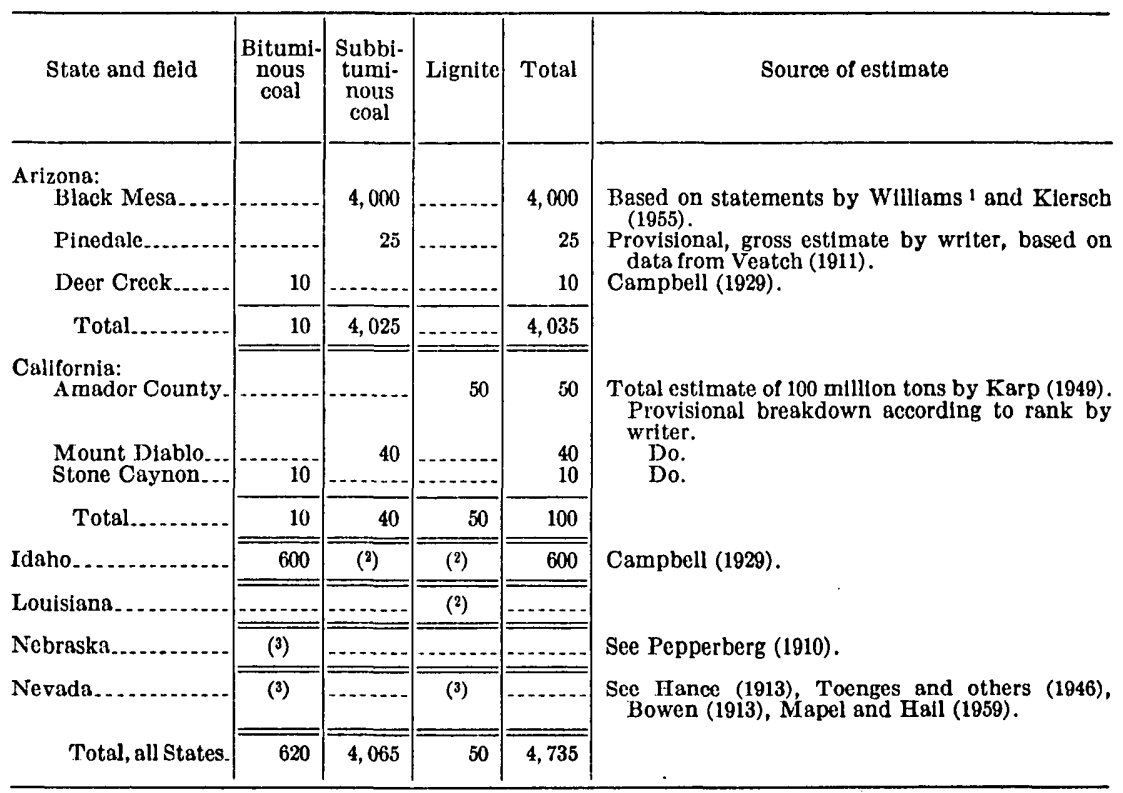

1 Williams, G. A., 1951, The coal deposits and Cretaceous stratigraphy of the western part of Black Mesa Arizona: Arizona Ưniv., unpublished $\mathrm{Ph}$. D. thesis.

'Small.

3 Insignificant.

Considering that some of the State estimates may be high and others low, and considering that no figures are provided for the small reserves of subbituminous coal and lignite in Idaho or lignite in Louisiana, it is likely that the totals for the six States are more accurate than the individual figures from which they were obtained.

\section{POSSIBLE ADDITIONAL RESERVES NOT INCLUDED IN ESTIM ATES}

In some States for which modern estimates have been prepared, large areas of coal-bearing rock have been omitted from consideration for want of specific information about the occurrence and thickness of the coalbeds. In Colorado, for example, 75 percent of the 
known area of coal-bearing rock was thus omitted; in Wyoming, 53.5 percent was omitted; in eastern Kentucky, 13 percent; and in North Dakota, 1.7 percent. When full and complete information is available about such areas, the estimated reserves will be increased substantially.

Because most mining and prospecting in the United States is done along surface outcrops, very little information is available about the occurrence of coal at depth or at a distance of more than a few miles from the outcrops, and no information is available about reserves in the centers of the large coal basins. Therefore, most of the estimated reserves, particularly in the States for which modern estimates have been prepared, are confined to a narrow zone a few miles wide parallel to the outcrops of the individual coalbeds. This is well illustrated by the fact that 88 percent of the reserves classified in figure $5 A$ is less than 1,000 feet below the surface. When exploration is pushed to greater distances from the outcrops and to greater depths, reserves should be increased correspondingly.

Many known coal-bearing areas, particularly those remote from present means of transportation or centers of use, have been mapped or examined only in reconnaissance. Reserve estimates for such areas tend to be small because of the paucity of information and because only the thicker and better beds are examined during reconnaissance work. The extension of detailed mapping in such areas should, therefore, yield data that will permit an increase in reserve estimates.

In many other areas, information about the thickness and nature of the coal-bearing rocks is so scanty that it is impossible to establish correlations between coalbeds in different parts of an area. Where correlations cannot be established, estimated reserves are restricted to areas near the known outcrops. Where correlations can be established, reserves can be inferred to exist at greater distances between the outcrops, and the total estimated reserves tend to be larger.

It is thus apparent that the newer estimates of reserves, based as they are on conservative assumptions, are minimum estimates, and that they will be increased in the future as additional information is acquired through geologic mapping and physical exploration.

\section{NEED FOR ADDITIONAL WORK}

The results of the current study of coal reserves show clearly the need for additional mapping and exploration. Although the recent estimates are an improvement over previous ones, primarily because they are presented in carefully defined categories, they point to many obvious deficiencies in the state of knowledge about the dis- 
tribution, extent, and correlation of coalbeds. Full knowledge about the coal resources of the United States is thus dependent on a continuing, active program of detailed geologic mapping and exploratory drilling in the coal field areas, accompanied by periodic inventories of reserves.

The cooperation between Government and industry in the accumulation, preservation, and analysis of coal reserve data, which has been so effective in the preparation of recent reserve estimates, should be strengthened and improved at every orportunity.

\section{OTHER ESTIMATES OF UNITED STATES COAL RESERVES}

Three earlier estimates of coal reserves in the United States have been prepared. These earlier estimates were intended for different purposes and were based on different definitions and procedures. As a result, they are neither directly comparable with each other nor with the present estimate. The points of similarity and difference between these three older estimates are summarized in the following paragraphs.

\section{R. CAMPBELL, 1909 TO 1929}

The Campbell $(1917,1929)$ estimate of coal reserves, which was published with revisions several times during the period from 1909 to 1929 , and which has been largely replaced by the present estimate, was an attempt to estimate the total reserves originally present in the ground. It made statistical allowance for coal as yet unmapped and undiscovered in all of the coal-bearing areas and, primarily for this reason, is larger than subsequent estimates.

In the Campbell estimate the following minimum thicknesses were used for the several ranks of coal:

Rank

Minimum thiekness

Bituminous coal and anthracite

(inches)

Subbituminous coal _..._- 24

Lignite 36

The estimate was based on an assumed specific gravity of 1.3 , or a weight of 1,770 tons per acre-foot for coal of all ranks, and included coal to a depth of 3,000 feet below the surface. Except for the major breakdown of reserves according to rank, all coal above the established minimum thicknesses was included in a single category.

According to the last revision of the Campbell estimate, published in 1929, the original coal reserves of the United States before mining began totaled 3,215 billion tons (Campbell, 1929). 


\section{UNITED STATES COAL COMMISSION COMMITTEE REPORT, 1922}

The recoverable coal reserves of the United States as of Jan. 1, 1922 , were estimated to be 1,634 billion tons, by a committee established by the United States Coal Commission. This committee, known at that time as the Engineers' Advisory Valuation Committee, was requested to estimate the market value of coal mines and of the coal in the ground. The Coal Commission did not accept the estimate of the valuation committee for use in their reports, but permission was given for separate publication by the committee (Am. Inst. Mining Metall. Engineers, 1924).

The committee's estimate of recoverable reserves, now largely of historic value, was based on the estimate of original reserves prepared by Campbell and on estimates of several State surveys. These estimates were reduced to allow for future mining losses and to exclude "thin and unavailable coal." No specific information as to the criteria used in reducing the basic original reserve figures is contained in the committee report. It is interesting to note, however, that if a 50 percent recovery is assumed, the recoverable reserves of the United States as of January 1, 1919, based on the Campbell estimate of that period, totaled 1,768 billion tons, whereas the recoverable reserves as of January 1, 1922, suggested by the valuation committee, totaled 1,634 billion tons.

A few writers have implied that the estimate of the valuation committee differed significantly from the Campbell estimate because they fail to emphasize the fact that the Campbell estimate was for original coal reserves in the ground, whereas the committee's estimate was for recoverable reserves as of January 1, 1922. The two estimates are in close accord when they are adjusted to the same basis of comparison.

\section{UNITED STATES ARMY CORPS OF ENGINEERS, 1952}

A survey of the United States to determine general areas suitable for the location of synthetic liquid fuel plants was completed in 1952 under the auspices of the Corps of Engineers, Department of the Army (1952). The estimated recoverable reserves of coal in the United States, as of January 1, 1949, considered during the survey, totaled about 170 billion tons, of which a maximum of 126 billion tons was deemed suitable for immediate large-scale use in the manufacture of synthetic liquid fuels.

The Corps of Engineers estimate of 170 billion tons for recoverable reserves is about 20 percent of the Geological Survey estimate of 830 billion tons presented in tables 1 and 2 of this report. The difference between the two estimates is explained by the different 
purposes for which they were intended and the different assumptions on which they are based.

The major objective of the Corps of Engineers survey was to outline large blocks of coal that would be immediately available for large-scale mining to supply hypothetical synthetic liquid fuel plants. The maximum depth of coal considered in the Corps of Engineers estimate, for example, is 1,500 feet; whereas, in the Geological Survey estimate the reserves of coal are computed in 3 categories: 0 to 1,000 feet, 1,000 to 2,000 feet, and 2,000 to 3,000 feet. The minimum thickness of coal considered for underground mining in the Corps of Engineers estimate is 24 inches for bituminous coal and 48 inches for lignite; whereas, the Geological Survey estimate includes in its several categories of thickness, bituminous coal in beds as thin as 14 inches and lignite in beds as thin as 30 inches.

The Corps of Engineers figure is thus a conservative statement of coal that is known to be immediately available for use under present mining conditions. It is roughly comparable with the U.S. Geological Survey estimate for measured and indicated recoverable reserves in beds 28 inches or more thick, and less than 1,000 feet below the surface. (See fig. 6.)

The larger figure of the U.S. Geological Survey includes, in separate categories, reserves of both present economic interest and possible future usefulness, and thus provides a more comprehensive statement of information available about the total coal reserves of the United States.

\section{PEAT RESERVES}

Peat, the first stage in the alteration of plants to coal, is the partly carbonized remains of roots, trunks of trees, twigs, seeds, shrubs, grasses, and mosses that have been covered or saturated with water so that decomposition is retarded. It contains a large proportion of the carbon of the original vegetable matter, and the plant structures of which it is composed generally are visible without the aid of a microscope. In general, peat accumulates on poorly drained land in regions of cool climate or high humidity, where evaporation is slow, and peat-forming plants may flourish.

Peat is an important fuel in Europe, but only small quantities have been produced as commercial fuel in the United States because of the abundance and superiority of coal. The United States contains large deposits of peat, however, and it is produced commercially for a variety of purposes other than as fuel. Air-dried peat is a source of concentrated organic matter, and it contains about 2 percent nitrogen. It is used in the United States principally for soil improvement and as an ingredient in commercial fertilizers. According to the U.S. Bureau of Mines (1959c), 327,813 short tons of peat was produced in this 
country in 1958. Of the total sold in 1958 , about 90 percent was used for soil improvement and about 10 percent for other purposes, which include litter for barns and poultry yards and packing material for plants, fruits, vegetables, eggs, and other fragile articles.

The United States contained original peat reserves totaling 13,827 million short tons, calculated on an air-dried basis, as estimated in a detailed report on peat by Soper and Osbon (1922, p. 92-93). Of this total, only about 3.5 million tons was mined between 1922 and 1958. The peat reserves occur primarily in local deposits distributed throughout two general regions. The northern peat region, which

Original reserves of peat in the United States, estimated on an air-dried basis, by regions and States

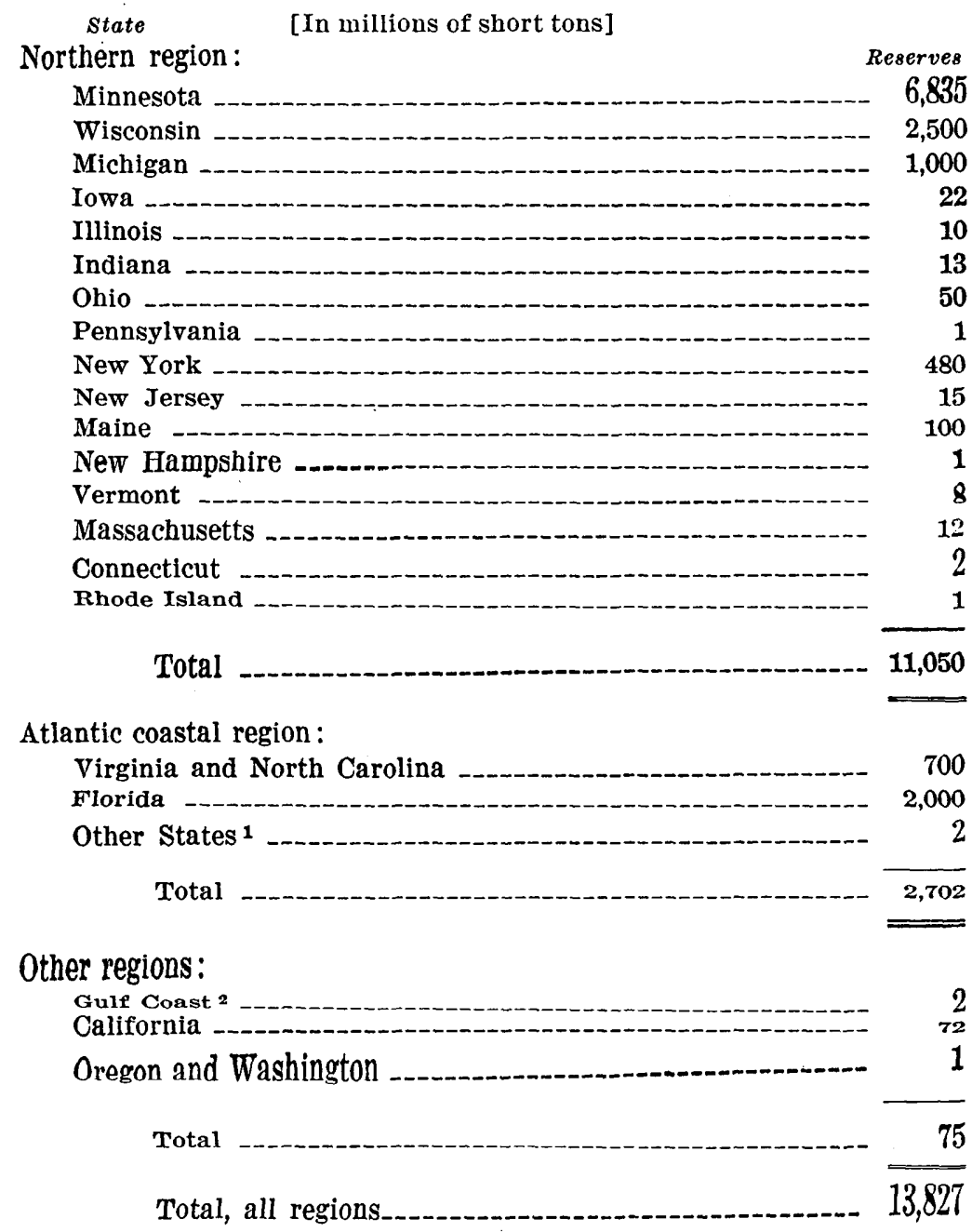

1 Includes Delaware, Georgia, Maryland, and South Carolina.

a Exclusive of Florida. 
contains about 80 percent of the total reserves, includes Minnesota, Wisconsin, Michigan, eastern South Dakota, the northern parts of Iowa, Illinois, Indiana, Ohio, and Pennsylvania, and New York, New Jersey, and the New England States. The Atlantic coastal region, which contains approximately 19 percent of the total reserves, includes the southern part of Delaware, the eastern parts of Maryland, Virginia, North Carolina, South Carolina, and Georgia, and all of Florida. Small deposits of peat also occur in a narrow belt of land adjoining the Gulf Coast; in the valleys of the Sacramento and San Joaquin Rivers and in Siskiyou, Los Angeles, Orange, and San Bernardino Counties, California; and in the basins of lakes and rivers in Oregon, Washington, and the Rocky Mountain States.

The accompanying table by Soper and Osbon shows the original reserves of peat in the United States, calculated on an air-dried basis, by regions and States. In addition to this general table, the report by Soper and Osbon includes tables of reserves classified by counties for the States having important peat reserves, as well as detailed descriptions of individual peat deposits.

\section{WORLD COAL RESERVES}

As shown in table 5, the remaining coal reserves of the World, as currently estimated, total 4,640,561 million metric tons, of which 49 percent is in Asia, 34 percent in North America, and 13 percent in Europe.

TABLE 5.-Estimated remaining coal reserves of the world by regions and by principal coal-producing countries ${ }^{1}$

[In millions of metric tons]

\begin{tabular}{|c|c|c|c|c|c|}
\hline \multirow{2}{*}{ Country } & \multirow{2}{*}{$\begin{array}{c}\text { Anthracite; } \\
\text { bituminous } \\
\text { and sub- } \\
\text { bituminous } \\
\text { coal }\end{array}$} & \multirow{2}{*}{$\begin{array}{l}\text { Lignite and } \\
\text { brown coal }\end{array}$} & \multirow{2}{*}{ Total } & \multicolumn{2}{|c|}{ Percent } \\
\hline & & & & $\begin{array}{c}\text { Region } \\
\text { total }\end{array}$ & $\begin{array}{l}\text { World } \\
\text { total }\end{array}$ \\
\hline \multicolumn{6}{|c|}{ Asia } \\
\hline $\begin{array}{l}\text { U.S.S.R. }{ }^{2} \\
\text { China } \\
\text { India } \\
\text { Japan- } \\
\text { Others }{ }^{-1}\end{array}$ & $\begin{array}{r}998,000 \\
1,011,000 \\
62,427 \\
9,897 \\
4,711\end{array}$ & $\begin{array}{r}202,000 \\
600 \\
3508 \\
258 \\
3,808\end{array}$ & $\begin{array}{r}1,200,000 \\
1,011,600 \\
62,935 \\
10,155 \\
8,519\end{array}$ & $\begin{array}{r}52.4 \\
44.1 \\
2.8 \\
.4 \\
.3\end{array}$ & $\begin{array}{r}25.9 \\
21.8 \\
1.4 \\
.2 \\
.1\end{array}$ \\
\hline Total & $2,086,035$ & 207,174 & $2,293,209$ & 100.0 & 49.4 \\
\hline \multicolumn{6}{|c|}{ North America } \\
\hline $\begin{array}{l}\text { United States }{ }^{5} \\
\text { Canada }{ }^{6} \\
\text { Mexico }{ }^{7}\end{array}$ & $\begin{array}{r}1,099,906 \\
62,472 \\
4,306\end{array}$ & $\begin{array}{r}405,970 \\
24,450\end{array}$ & $\begin{array}{r}1,505,876 \\
86,926 \\
4,306\end{array}$ & $\begin{array}{r}84.1 \\
5.6 \\
.3\end{array}$ & $\begin{array}{r}32.4 \\
1.9 \\
.1\end{array}$ \\
\hline Total........ & $1,166,684$ & 430,420 & $1,597,104$ & 100.0 & 34.4 \\
\hline
\end{tabular}

See footnotes at end of table.

586968-61-7 
TABLE 5.-Estimated remaining coal reserves of the world by regions and $b y$ principal coal-producing countries-Continued

[In millions of metric tons]

\begin{tabular}{|c|c|c|c|c|c|}
\hline \multirow{2}{*}{ Gountry } & \multirow{2}{*}{$\begin{array}{l}\text { Anthracite; } \\
\text { bituminous } \\
\text { and sub- } \\
\text { bituminous } \\
\text { coal }\end{array}$} & \multirow{2}{*}{$\begin{array}{l}\text { Lignite and } \\
\text { brown coal }\end{array}$} & \multirow{2}{*}{ Total } & \multicolumn{2}{|c|}{ Percent } \\
\hline & & & & $\begin{array}{l}\text { Region } \\
\text { total }\end{array}$ & $\begin{array}{l}\text { World } \\
\text { total }\end{array}$ \\
\hline \multicolumn{6}{|c|}{ Europe } \\
\hline $\begin{array}{l}\text { Germany } \\
\text { United Kingdom } \\
\text { Poland } \\
\text { Czechos'ovakia. } \\
\text { France } \\
\text { Belgium } \\
\text { Netherlands } \\
\text { Others }{ }^{10} \text {.... }\end{array}$ & $\begin{array}{r}224,300 \\
170,686 \\
80,000 \\
6,450 \\
12,288 \\
5,988 \\
3,400 \\
2,622\end{array}$ & \begin{tabular}{lr|}
8 & 62,000 \\
$(8)$ & 18 \\
& 18 \\
12,500 \\
& 430 \\
$(8)$ & \\
$(8)$ & \\
22,154
\end{tabular} & $\begin{array}{r}286,300 \\
170,686 \\
80,018 \\
18,950 \\
12,718 \\
5,988 \\
3,400 \\
24,776\end{array}$ & $\begin{array}{r}47.5 \\
28.3 \\
13.3 \\
3.1 \\
2.1 \\
1.0 \\
4.1\end{array}$ & $\begin{array}{r}6.2 \\
3.7 \\
1.7 \\
.4 \\
.3 \\
.1 \\
.1 \\
.5\end{array}$ \\
\hline Total & 505,734 & 97,102 & 602,836 & 100.0 & 13.0 \\
\hline \multicolumn{6}{|c|}{ Africa } \\
\hline $\begin{array}{l}\text { Union of South Africa } \\
\text { Others } 11\end{array}$ & $\begin{array}{r}68,000 \\
1,650 \\
\end{array}$ & (8) 200 & $\begin{array}{r}68,000 \\
1,850\end{array}$ & $\begin{array}{r}97.4 \\
2.6 \\
\end{array}$ & (8) 1.5 \\
\hline Total--- & 69,650 & 200 & 69,850 & 100.0 & 1.5 \\
\hline \multicolumn{6}{|c|}{ Australasia } \\
\hline $\begin{array}{l}\text { Australia } \\
\text { Others }{ }^{12}\end{array}$ & $\begin{array}{r}16,800 \\
99 \\
\end{array}$ & $\begin{array}{r}41,000 \\
785\end{array}$ & $\begin{array}{r}57,800 \\
-884\end{array}$ & $\begin{array}{r}98.5 \\
1.5\end{array}$ & (8) 1.3 \\
\hline Total. & 16,899 & 41,785 & 58,684 & 100.0 & 1.3 \\
\hline
\end{tabular}

South and Central America

\begin{tabular}{|c|c|c|c|c|c|}
\hline $\begin{array}{l}\text { Colombia } \\
\text { Venezuela. } \\
\text { Others } 13\end{array}$ & $\begin{array}{r}12,000 \\
3,068 \\
3,556\end{array}$ & $\begin{array}{r}0 \\
254\end{array}$ & $\begin{array}{r}12,000 \\
3,068 \\
\mathbf{3}, 810\end{array}$ & $\begin{array}{l}63.6 \\
16.2 \\
20.2\end{array}$ & $\begin{array}{ll}\text { (8) } & 0.8 \\
\text { (8) } & \end{array}$ \\
\hline Total & 18,624 & 254 & 18,878 & 100.0 & 0.4 \\
\hline World total & $3,863,626$ & 776,935 & $4,640,561$ & 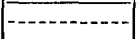 & 100.0 \\
\hline
\end{tabular}

1 Brown, Frederick, 1948, 1950, 1952, 1954, 1956, Statistical Yearbooks of the World Power Conference nos 4, 5,6,7 and 8. Central Office. World Power Conference, London. United Nations, 1952, Coal and iron ore resources of Asia and the Far East: Economic Commission for Asia and the Far East, Mineral resources development ser. 1, p. 18. United Nations, 1953, Development of mineral resources in Asia and the Far East: Economic Commission for Asia and the Far East, p. 143-199. United Nations, 1956, Lignite resources of Asia and the Far East, their exploration, exploitation and utilization: Economic Commission for Asia and the Far East, Mineral resources development ser. 7, p. 2-9. United Nations, 1957, Energy in Latjin America: Economic Commission for Latin America, p. 220-228.

2 Total for European U.S.S.R. included with Asiatic U.S.S.R.

8 Proved reserves only.

- Includes Burma, Indochina, Indonosia, Korea, Malaya, Manchuria, North Borneo, Pakistan, Philippines, Sarawak, Thailanc

$\checkmark$ Estimates of remaining reserves in tables 1 and 2 converted to metric tons.

- Includes only minable reserves.

8 Negligible.

- Beds not less than $50 \mathrm{~cm}$ thick.

10 Includes Austria, Bulgaria, Denmark, Greece, Hungary, Ireland, Italy, Norway, Portugal, Roumania,

Swedon, and Yugoslavia
11 Includes Algeria, Belgian Congo, French Moroceo, Madagascar, Nigerta, and Tanganyika.

12 Includes New Caledonia and New Zealand.

18 Includes Argentina, Brazil, Chile, Honduras, and Peru.

Most of the figures in table 5 are for remaining reserves as of various dates in the period between 1913 and 1060 ; others are for original reserves. This minor discrepancy does not affect the relative standing of any country or continent to a significant degree. All 
figures in the table are in metric tons, the standard unit for measuring coal in most countries. One metric ton is equivalent to 2,205 pounds, or about 1.1 short tons.

With remaining reserves of $1,505,876$ million metric tons of coal, as currently estimated, the United States seems to have 32 percent of the total remaining World coal reserves and 94 percent of the remaining reserves on the North American Continent.

Because of the different methods of calculating coal reserves, the different standards of thickness and depth adopted, and the different dates for which estimates were made for individual countries, the figures shown in the table are comparable only to the extent that they show the general order of magnitude of the reserves in each country. In particular, the revisions in recent years of methods of calculating coal reserves by some countries, and continued adherence to older methods by others, mean that some figures in the table are conservative and represent only immediately accessible proved coal in thick beds, whereas other figures are much more comprehensive and include total reserves in thick and thin beds without regard to quality, minability, or accessibility of the coal.

Canada provides an example of the effect of changes in methods and viewpoint in calculating coal reserves. In 1913, the remaining coal reserves of Canada were estimated to total 1,216,770 million metric tons (Internat. Geol. Cong. 12th, 1913). In 1946, however, the remaining coal reserves were reestimated to total only 89,644 million metric tons, which amount is less than 8 percent of the earlier figure (MacKay, 1946). The 1913 estimate assumed broad continuity of coalbeds based on few observations, and made statistical allowance for all possible coalbeds to a minimum thickness of 1 foot and to a maximum depth of 4,000 feet below the surface. The 1946 estimate included only known, developed, or explored beds, which for reasons of thickness, quality, and extraction costs were considered economically minable in 1946.

Reserves for most other countries shown in table 5 relate to all coal in the ground irrespective of quality, minability, or accessibility, and many of these figures, particularly the older ones, will no doubt be reduced in the future as more detailed information becomes available and as more restrictive methods of calculating reserves are adopted.

\section{RELATION OF COAL IN THE UNITED STATES TO OTHER FORMS OF ENERGY}

The industrial machine of the United States annually consumes prodigious quantities of energy. The mineral fuels and waterpower produced in 1959, for example, contained the heat equivalent of 


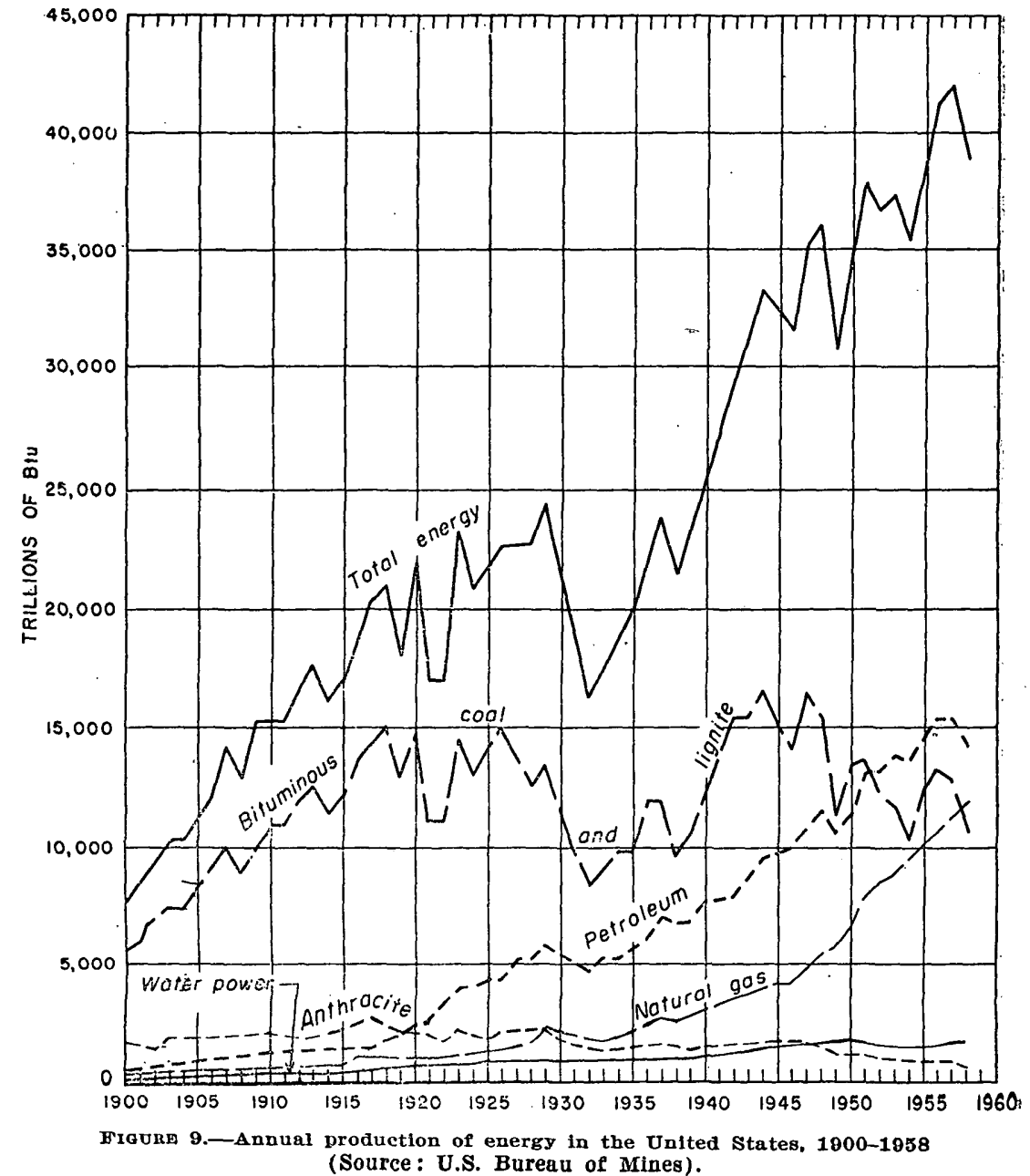

10 horsepower of mechanical energy per person operating continuously throughout the year. Furthermore, the production and use of energy are increasing annually at a very rapid rate. As shown in figure 9, the overall use of energy in the United States has quadrupled in the last 50 years and has doubled in the last 25 years. And the curve is still headed sharply upward. This upward surge in the use of energy is impelled in part by our rapidly growing. population, which has doubled in the last 50 years, and in part by our increased reliance on machines and manufactured products. Considering the potential future increase in population, in use of energy, and in technologic improvement in the production of energy; the curve is likely to rise steeply and more or less continuously throughout the forseeable future. With consumption of energy in 


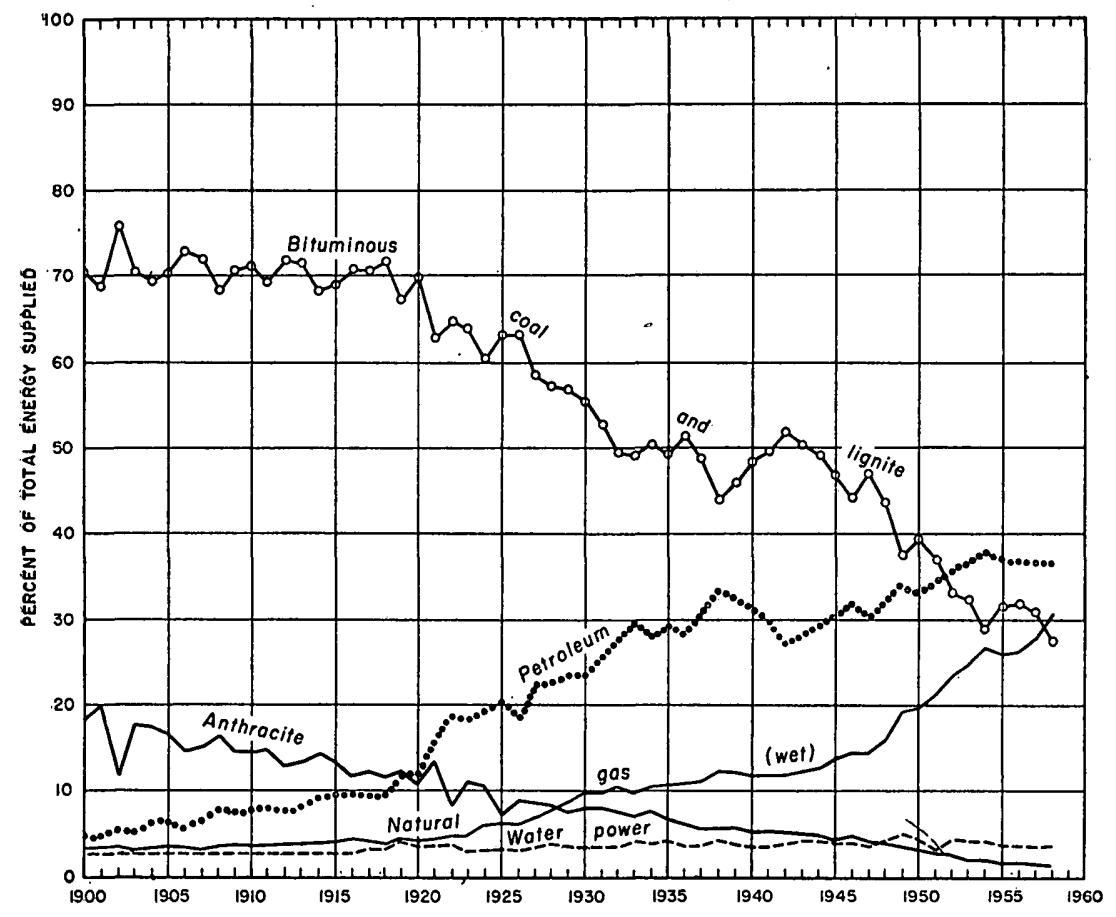

FigUR: 10.-Percentage of total energy supplied by mineral fuels and waterpower, 1900-58 (Source: U.S. Bureau of Mines).

progress on such an enormous and ever-increasing scale, it is interesting and instructive to review the position of coal in the total energy pattern.

During 1958, a year, second to 1957 in the use of fuel in the United States, coal supplied only 29 percent of the total energy produced from all sources, whereas petroleum and natural gas supplied 67 percent. The remaining 4 percent was supplied by waterpower (U.S. Bur. Mines, 1959a, p. 113). As shown in figure 10, the percentage of total energy supplied by coal, including bituminous and subbituminous coal, lignite, and anthracite, has decreased steadily from about 90 percent in 1900 to the present record low of 29 percent.

The percentage decrease in use of coal through the years has been accompanied by a corresponding percentage increase in the use of petroleum and natural gas, which have had greater consumer appeal because of their convenience, and which have filled a number of new uses not competitive with coal. Included in the percentage figures for petroleum and natural gas, for example, are gasoline and diesel oils used in automobiles and trucks, heavy oils used in road construction and maintenance, natural gas consumed in the manufacture of carbon black, and lubricants. 
The decrease in the percentage contribution of coal to the total production of energy in the United States has not been accompanied by a comparable decrease in the actual production of coal. (See fig. 9.) More accurately, the production of coal leveled off at the end of the First World War, and for most subsequent years has ranged between 400 and 600 million tons. The lowest recorded production was in 1932 when only 360 million tons was mined, and the highest was in 1947 when 688 million tons was mined (U.S. Bur. Mines, 1959a, p. 112). The position of coal in the industrial economy is bolstered by its increased use in the production of electricity and in the manufacture of steel. In a report to the Panel on the Impact of the Peaceful Uses of Atomic Energy, a subcommittee of the Joint Committee on Atomic Energy (1956, p. 78), a group of engineers in the Department of the Interior concluded that the production of coal would hold relatively firm over the near term; and, assuming normal industrial growth and no significant competition from atomic energy, would increase to something in the range between 674 and 910 million tons by 1975 .

\section{PROBLEMS OF COMPARING ESTIMATES OF FUELS RESERVES}

Estimates of coal reserves cannot be compared readily with estimates of petroleum and natural gas reserves because the two kinds of fuels occur largely in different environments, and the reserves are calculated in different ways.

Coal-bearing rocks are near the surface in most parts of the United States, and the gross distribution and thickness of these rocks have been known for many years. Because coal occurs in these rocks in tabular bodies of fairly uniform breadth and thickness, estimates of the total quantity in the ground can be made with reasonable accuracy wherever data are available. Although precise information as to the thickness and number of coal beds is currently available only for areas near the outcrops, the known volume of coal-bearing rock is a primary factor limiting the magnitude of ultimate coal reserves.

The total reserves of bituminous sandstone and oil shale can be estimated with similar accuracy because these substances also occur in tabular bodies that may be studied at the surface, and because the area and thickness of the enclosing rocks are equally well known.

Petroleum and natural gas, on the other hand, are highly mobilo substances. Originally present as widely disseminated minute globules in sedimentary rocks, they move underground through pore spaces in the rocks, and accumulate only where traps or barriers prevent further migration. As a great variety of subsurface structural and stratigraphic relations create such traps, the total number 
existing in the widespread thick sequences of sedimentary rocks in the United States cannot be predicted accurately, nor can the ultimate amount of recoverable oil contained in these traps be ascertained. In many respects the ultimate amount of oil to be found is determined by an ever-improving technology in methods of exploration, drilling, and recovery. Today, for example, wells 25,000 feet deep are entirely practicable, whereas only a few years ago the limit was in the range of 5,000 to 10,000 feet.

Because petroleum and natural gas deposits are hidden deeply below the surface, only minimum proved reserves in developed areas can be estimated with reasonable accuracy. For the same reason, estimates of ultimate reserves are little more than conservative statements of opinion based on estimates of proved reserves and on the existing technology.

Consequently, the estimates for petroleum and natural gas tend to be ultraconservative, and they must be changed frequently to accord with new discoveries and improved methods of recovery.

Despite the recognized difficulty of comparing reserve estimates for the several mineral fuels, it is possible to show the approximate relative magnitude of reserves as currently estimated by converting all estimates to their total heat-value equivalents and by making certain adjustments to allow for differences in the methods of making calculations. Estimates of the reserves of various fuels are thus presented in table 6, which shows both in standard units of measure and in quadrillions of Btu the estimated recoverable reserves of coal as of Jan. 1, 1960, and the estimated recoverable reserves of petroleum, natural gas, bitumen, and oil from oil shale in the United States as of Jan. 1, 1959. The table gives the reserves of these individual fuels under two headings according to two major points of view: The heading, "Measured or proved reserves," includes only measured reserves of coal in beds 28 inches or more thick and less than 1,000 feet below the surface, and proved reserves of petroleum and natural gas as currently estimated. The heading, "Total reserves," includes total measured, indicated, and inferred reserves of coal in all categories of thickness and overburden, and ultimate reserves of petroleum and natural gas as currently estimated. The figures under the first heading are thus markedly more conservative than those under the second.

\section{MEASURED OR PROVED RESERVES}

The figure of 50 billion tons used for coal in column 1 of table 6 is 6 percent of the total recoverable reserves shown in table 1 . This fraction is intended to represent measured reserves in beds 28 inches or more thick and less than 1,000 feet below the surface. It was 
TABLE 6.-Comparison between remaining recoverable reserves of coal and other fuels in the United States, as of Jan. 1, 1959-60

\begin{tabular}{|c|c|c|c|c|c|c|c|}
\hline \multirow[b]{2}{*}{ Mineral fuel } & \multicolumn{3}{|c|}{$\begin{array}{l}\text { Measured or proved } \\
\text { reserves in- }\end{array}$} & \multicolumn{3}{|c|}{ Total reserves ${ }^{1}$ in -} & \multirow{2}{*}{$\mid \begin{array}{c}\text { Aver- } \\
\text { age } \\
\text { annual } \\
\text { pro- } \\
\text { duction } \\
\text { 1957-59 } \\
\text { (quad- } \\
\text { rillions } \\
\text { of Btu) } \\
(7)\end{array}$} \\
\hline & $\begin{array}{c}\text { Stand- } \\
\text { ard } \\
\text { units of } \\
\text { meas- } \\
\text { ure 2 } \\
\text { (1) }\end{array}$ & $\begin{array}{c}\text { Quad- } \\
\text { rillions } \\
\text { of } \\
\text { Btu } \\
\\
\text { (2) }\end{array}$ & $\begin{array}{c}\text { Percent } \\
\text { accord- } \\
\text { ing } \\
\text { to Btu } \\
\text { content } \\
\text { (3) }\end{array}$ & $\begin{array}{l}\text { Stand- } \\
\text { ard } \\
\text { units of } \\
\text { meas- } \\
\text { ure }{ }^{2} \\
\text { (4) }\end{array}$ & $\begin{array}{c}\text { Quad- } \\
\text { rillions } \\
\text { of } \\
\text { Btu } 8 \\
\\
(5)\end{array}$ & $\begin{array}{c}\text { Percent } \\
\text { accord- } \\
\text { ing } \\
\text { to Btu } \\
\text { content } \\
(6)\end{array}$ & \\
\hline 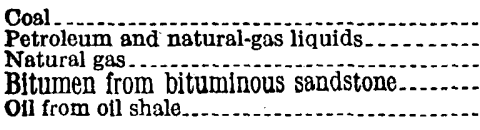 & $\begin{array}{r}: 50 \\
837 \\
0254 \\
100.65 \\
12250 \\
\end{array}$ & $\begin{array}{r}1,038 \\
204 \\
263 \\
4 \\
1,450\end{array}$ & $\begin{array}{r}35 \\
7 \\
9 \\
(11) \\
49\end{array}$ & $\begin{array}{r}3830 \\
7436 \\
71,842 \\
10126 \\
13700\end{array}$ & $\begin{array}{r}17,307 \\
82,373 \\
1,906 \\
7 \\
4,060 \\
\end{array}$ & $\begin{array}{r}68 \\
9 \\
7 \\
711) \\
16\end{array}$ & (ii) \\
\hline Total. & $\cdots$ & 2,959 & 100 & -..- & 25,653 & 100 & 40 \\
\hline
\end{tabular}

1 Measured, Indicated, and inferred reserves of coal in all categories of thickness and overburden; ultimate reserves of petroleum and natural gas.

2 Coal in billions of tons, petroleum, natural-gas liquids, bitumen from bituminous sandstone, and oil from oil shale in billions of barrels, and natural gas in trillions of cubic feet.

8 Reserves and production flgures converted to Btu according to the following heat values: anthracite,

12,700 Btu per lb; bituminous coal, 13,100 Btu per lb.; subbituminous coal, 9,500 Btu per lb.; lignite, 6,700

Btu per lb.; petroleum, oil from oil shale, and bitumen from bituminous sandstone, 5,800,000 Btu per bbl.; natural-gas liquids, 4,011,000 Btu per bbl.; and natural gas, $1,035 \mathrm{Btu}$ per cu. $\mathrm{ft}$.

6 percent of total recoverable reserves shown in table 1. This figure is intended to represent measured recoverable reserves in beds 28 in. or more thick, and less than $1,000 \mathrm{ft}$. below the surface as of Jan. 1, 1960 .

Percentage determined by consideration of 15 States in which reserves have been classified in detail.

(See fig. 6.)

From table 1.

- Proved reserves. Estimate by the American Petroleum Institute as reported in the Oil and Gas Journal, จ. 57, no. 13, p. 49-50, Mar. 23, 1959.

7 See accompanying text.

- Btu content calculated on the assumption that 20 percent of recoverable ultimate reserves will be naturalgas liçiids.

- Proved reserves. Estimate by the American Gas Association as reported in the Oil and Gas Journal, v. 57, no. 13, p. 50, Mar. 23, 1959

1050 percent of estimated reserves of bitumen in bituminous sandstone deposits near Vernal and Sunnyside, Utah; Casmalia, Santa Cruz, Edna, Sisquoc, Sulphur Mountain, and San Ardo, Calif.; and Uvalde, Tex. Estimate incomplete.

11 Negligible.

1250 percent of reserves of oil in oil shale containing $25 \mathrm{gal}$. of oil per ton, as estimated by Duncan (1958).

1350 percent of reserves of oll in oil shale containing 15 gal. of oil per ton, as estimated by W. B. Cashion,

Jr., J. R. Donnell, and R. L. Griggs (oral communcation, 1959)

obtained from figure 6, which is based on a consideration of the distribution of reserves in 15 States for which the reserves of coal have been classificd in detail. As these 15 States contain about half of the total reserves in the United States and include coal deposits of diverse ages, ranks, and types, the average observed distribution of reserves in the selected restricted category in these States is believed to be reasonably typical of the United States as a whole.

The figures used for petroleum, natural-gas liquids, and natural gas in column 1 of table 6 are proved reserves as currently estimated by the American Petroleum Institute and the American Gas Association (Oil and Gas Journal, 1959b).

The figures for bitumen in bituminous sandstone are based on similar conservative assumptions, as explained in the footnotes to the tables. 
For oil shale it is not possible to make a separation of reserves according to the reliability of data. Instead, the separation shown in table 6 is based on oil content alone. Column 1 includes reserves of oil in oil shale containing 25 gallons or more per ton, and column 4 includes reserves of oil in oil shale containing 15 gallons or more per ton. On this basis, oil in oil shale containing 25 gallons or more per ton represents 36 percent of the total containing 15 gallons or more per ton. This is a relatively high percentage as compared to the percentage of measured or proved reserves of other fuels.

\section{TOTAL RESERVES}

The figure of 830 billion tons used for coal in column 4 of table 6 is the total recoverable reserves shown in table 1 . It includes measured, indicated, and inferred reserves in beds 14 inches or more thick and in beds to depths of 3,000 feet below the surface.

Several attempts have been made to prepare estimates for total (measured, indicated, and inferred) reserves of petroleum and natural gas. Such estimates are usually termed "ultimate reserves" and are intended to include past production, present proved reserves, and estimated future discoveries. These estimates are for recoverable reserves, based on present experience, plus some allowance for future improvement in recoverability. Estimates of ultimate reserves are inherently very conservative because they are based on proved reserves and on the present technologic status of the industry. Largely because of continued success in exploration, continued improvement in drilling machinery and techniques, and continued improvement in production practices, estimates of ultimate reserves have to be increased every few years in spite of large annual increases in consumption.

Although no special accuracy is claimed for estimates of ultimate reserves, the largest and most recent figures available will provide some basis for comparison with coal and other fuels.

Weeks (1958) estimated the ultimate recoverable reserves of petroleum and natural-gas liquids in the United States recoverable by primary methods to be 240 billion barrels, and suggested that an equal amount might eventually be recovered by improved secondary recovery methods. The 2 figures combined yield an estimate of 480 billion barrels for ultimate reserves.

More recently, Weeks (1959) increased the first figure to 270 billion barrels, and lowered the second to 190 billion barrels. The 2 new figures combined yield an estimate of 460 billion barrels for ultimate reserves.

Both of the Weeks estimates made allowance for future reserves from the continental shelves, but neither made allowance for Alaska. 
The ultimate petroleum reserves of Alaska and adjoining continental shelves have been estimated by a group of geologists of the U.S. Geological Survey to be on the order of 30 billion barrels (George Gryc, oral communication, 1959).

Adding the 30 billion barrel figure for Alaska to the 2 Weeks figures of 480 and 460 billion barrels yields figures of 510 and 490 billion barrels, respectively, for the ultimate petroleum reserves of the United States and continental shelves. Because the 2 figures were obtained by subjective methods and are close together, the intermediate rounded figure of 500 billion barrels has been selected for use in this report.

This assumed figure, of course, is intended to represent the total, ultimately recoverable reserves of petroleum and natural-gas liquids before production began; that is, past production, present proved reserves, and assumed future discoveries. To make it comparable with figures for recoverable reserves of coal and other fuels as of Jan. 1, 1959, it must be reduced by the amount of past production. The cumulative past production of petroleum and natural-gas liquids to Jan. 1, 1959, totals about 64 billion barrels. Subtracting this number from the estimated ultimate reserves of 500 billion barrels leaves 436 billion barrels as the estimated recoverable reserves on Jan. 1, 1959. This figure appears in column 4 of table 6 .

Miller (1958) has prepared two estimates of the ultimate naturalgas reserves of the United States-one of 1,150 and the other of 1,700 trillion cubic feet. The larger of the Miller estimates was based on the assumption that the ultimate reserves of petroleum recoverable by primary methods total 275 billion barrels, and that the search for and production of petroleum yet to be discovered will yield an average of 7,000 cubic feet of gas per barrel of petroleum. This estimate made no allowance for Alaska.

The information now available requires establishment of a slightly larger estimate of ultimate natural-gas reserves than that determined by Miller. With the inclusion of Alaska in the estimates, the ultimate reserves of petroleum in the United States recoverable by primary methods is estimated to total 300 billion barrels. The amount of gas discovered per barrel of oil has also increased steadily throughout the past, and during the period 1956-58 averaged about 7,990 cubic feet. It seems certain that the amount of gas discovered in the future will average more than 8,000 cubic feet per barrel, and therefore this larger factor is a reasonable one to use in estimating future reserves of gas.

Following the method of Miller and using the two new factors, the following calculation yields an estimate of 2,004 trillion cubic feet as the ultimate natural gas reserves of the United States: 
300 Ultimate reserves of petroleum recoverable by primary methods (billion barrels)

-101 Past production plus proved reserves as of Jan. 1, 1959 (billion barrels)

199 Petroleum yet to be discovered (billion barrels)

$\times 8$ Natural gas assumed to be discovered per barrel of petroleum (thousand cubic feet)

1, 592 Natural gas yet to be discovered (trillion cubic feet)

+412 Past production plus proved reserves as of Jan. 1, 1959 (trillion cubic feet)

2, 004 Ultimate reserves natural gas (trillion cubic feet)

Because the two main factors in the calculation are based on broad assumptions, the more appropriate rounded figure of 2,000 trillion cubic feet has been selected for use in this report.

The cumulative past production of natural gas to January 1, 1959, totals about 158 trillion cubic feet (Oil and Gas Jour., 1959a, p. 136). Subtracting this amount from the estimated ultimate reserves of 2,000 trillion cubic feet leaves 1,842 trillion cubic feet as the recoverable reserves on January 1, 1959. This figure also appears in: column 4 of table 6 .

It must be emphasized that the selected figures of 500 billion barrels for the ultimate reserves of petroleum and natural-gas liquids and of 2,000 trillion cubic feet for the ultimate reserves of natural gas are not studied revisions of existing estimates. They are introduced merely to provide a fair and convenient basis for comparison of reserves of these fuels with reserves of coal.

The figures for ultimate reserves of bitumen from bituminous sandstone and oil from oil shale were obtained from sources cited in the footnotes to table 6.

The preponderance of coal in the total fuel reserves picture as currently estimated is clearly shown in columns 3 and 6 of table 6 . Considering only column 6 , coal represents 68 percent of the total reserves of fuel in the United States, whereas petroleum, naturalgas liquids, and natural gas together represent only 16 percent.

Based as they are upon several assumptions of various orders of reliability, the calculated percentage figures obviously express the relation between the several kinds of mineral fuels in a qualitative rather than in an exact sense. This should not detract from their value and interest.

In view of the relatively large reserves of coal and the relatively small reserves of petroleum and natural gas, it is instructive to consider the rates at which these fuels are currently being produced and consumed. In column 7 of table 6 , the average annual production of each fuel during the 3-year period, 1957-59, has been con- 
verted to quadrillions of $\mathrm{Btu}$. On this uniform basis it will be noted that the production of petroleum, natural-gas liquids, and natural gas combined is more than twice the production of coal. Thus, petroleum, natural-gas liquids, and natural gas, which represent 16 percent of the total fuel supply, are being use more than twice as fast as coal, which represents 68 percent of the fuel supply. This disproportionate ratio points to the day when we shall be forced to place greater reliance on coal or else develop and vastly expand other sources of energy.

\section{LIFE EXPECTANCY OF UNITED STATES FUEL RESERVES}

Because of the many imponderable factors to be taken into consideration, it is impossible to estimate the life expectancy of fuel reserves in the United States with any degree of accuracy. Even so basic a factor as the magnitude of the reserves is, at best, but an approximation based on data currently available, and is therefore subject to change in the future. Other factors, such as the observed increase in population and use of energy, increase in efficiency in production and use of fuel, imports of fuel oil, and the possibility of developing new sources of energy, are highly variable and so closely related as to defy precise analysis. A few of these factors are discussed briefly in the following paragraphs as a means of emphasizing the uncertainty attending statements about the life expectancy of fuel reserves.

The estimates of reserves presented in this report and used as a basis for this discussion of life expectancy are based on information currently available. The information is admittedly incomplete, and, with the experience of the past as a guide, it seems safe to predict that the total reserves of all fuels, particularly reserves of petroleum and natural gas, ultimately will be found to be larger than the present figures suggest.

In considering the life expectancy of fuel reserves, it is necessary to make generous allowance for the probable future increase in use of fuel. The only yardstick for this purpose is the experience of the past 50 years. During this period an unprecedented fourfold increase in the use of energy has taken place, due in part to an increase in population, and in part to an increase in the per capita use of energy. It is difficult to project such a steeply rising trend far enough into the future to be meaningful, but any projection will yield results of very large magnitude. Weeks (1959) has recently examined this trend and has concluded that the world demand for energy in the year 2059 will be at least 40 times, and probably 50 times, as much as the demand in 1959. 
In the production of petroleum, recoverability has increased steadily throughout the years, and this is one of the reasons why proved reserves of petroleum tend to increase annually. Similarly, many methods have been devised to improve recoverability in coal mining. In this report the recoverable reserves of coal are assumed to be only 50 percent of the total reserves in the ground, which factor accords with the past average experience in a number of mining districts. The recoverability from a number of individual mines: is much higher than 50 percent, however, and overall recoverability in coal mining could be increased considerably, perhaps to 65 percent. Also, many thin or deeply buried coalbeds, not now considered to be recoverable, or areas now considered to be mined out, may ultimately be included as recoverable reserves if underground gasification techniques can be devised. (See Elder and others, 1957.) Any increase in the recoverability of fuels can be expressed directly as an increase in reserves.

Improvement in the use of fuels is illustrated by the marked economies introduced in the production of electricity at electric utility plants in the United States. In 1920, for example, an average of 3 pounds of coal was required to produce 1 kilowatthour of electricity, whereas by 1958 , only 0.90 pound was required (U.S. Bur. Mines, 1959a, p. 107). Possible future improvement in the use of fuels would permit a comparable increase in estimates of life expectancy of reserves.

The form in which the energy in coal is used is perhaps the largest indeterminable factor that enters into any consideration of the life expectancy of coal reserves. If the future uses of coal are considered for a long period, It is apparent that for many years to come the uses will be the same as at present. Wrather and others (1950), however, have pointed out that the United States is committing itself to a liquid- and gaseous-fuel economy, and ultimately coal may become an important material for synthesis of these fuels in addition to filling the requirements for solid fuel. If such conversion of coal becomes general, the need for coal will be enormous because, on the basis of present technology, about 50 percent of the potential energy in coal is lost in the conversion to liquid fuel (Ayres and Scarlott, 1952, p. 113).

The large reserves of petroleum in the Near East, Venezuela, Mexico, and elsewhere are needed only in small quantities at the points of origin. Some of this petroleum is finding, and probably will continue to find, a market in the United States, which is at present the largest consumer of petroleum products in the world. In 1958 such net imports of crude and residual oil and distillate represented a record 15.3 percent of domestic demand (Oil and Gas 
Jour., 1959a). The life expectancy of domestic fuel will be lengthened to the extent that foreign fuel is imported.

The life expectancy of fossil fuel reserves will be lengthened to the extent that other energy resources such as atomic energy, solar energy, earth heat, and tides can be utilized. (See United Nations, 1955.) Atomic energy is already in use as a source of electricity in full-scale experimental utility plants and a further expansion in use seems inevitable. Solar energy is likewise in use on a very small scale in special applications such as powering radios in satellites and telephones in remote rural areas. Ayers and Scarlott (1952, p. 279-283) believe that solar energy as a benign large-scale constant energy source deserves greater attention as a source of commercial electricity than it has yet received.

Appraisal of the life expectancy of any individual fuel is further complicated by the fact that most fuels can be used interchangeably, and at most installations the choice of fuel is determined largely by cost. The preferred position of petroleum and natural gas in the fuel economy is due to the present abundance, comparative economy, and convenience of these fuels and will, therefore, continue as long as adequate quantities of petroleum and natural gas can be produced in the United States, and as long as imported petroleum is available in domestic markets. On the other hand, as petroleum and natural gas become more expensive, many users of these fuels will convert to more economical sources of energy. Thus, long before petroleum and natural gas reserves in the United States are exhausted, we may expect increasing reliance to be placed on other energy sources, a trend in which coal may contribute substantially. This period of transition may be greatly lengthened by utilization of imported supplies of petroleum, and it will be obscured by fluctuations in the economic cycle and by irregularities in the rate of discovery of new petroleum and natural-gas fields. Because the life expectancy of petroleum and natural-gas reserves will be greatly extended as the relative use of coal and other energy sources is increased, and because of future additions to reserves of petroleum, natural gas, and coal, a realistic estimate of the life expectancy of any of these fuels is not possible.

Although it is thus impossible to predict the life expectancy of coal and other mineral fuels, the ratios between the estimated reserves and recent annual production provide figures that are more meaningful for comparative purposes than the reserve figures alone. As shown in the accompanying table, the measured recoverable reserves of coal in beds 28 inches or more thick and less than 1,000 feet below the surface are 86 times the average annual production during the 3-year period from 1957 to 1959 inclusive, whereas the 
proved reserves of petroleum and natural-gas liquids are only 13 times the recent average annual production, and the proved reserves of natural gas are only 22 times the recent average annual production. A similar relation exists between total reserves. The total recoverable reserves of coal are 1,442 times recent annual production, whereas the ultimate reserves of petroleum and natural-gas liquids, as currently estimated, are only 148 times recent annual production and the ultimate reserves of natural gas, as currently estimated, are only 159 times recent annual production.

Ratios of remaining recoverable reserves of coal and other fuels to average annual production, $1957-59$

\begin{tabular}{|c|c|c|}
\hline \multirow{2}{*}{ Fuel } & \multicolumn{2}{|c|}{$\begin{array}{l}\text { Ratios of remaining recoverable } \\
\text { reserves to average annual produc- } \\
\text { tion, 1957-59 }\end{array}$} \\
\hline & $\begin{array}{l}\text { Measured } \\
\text { reserves of } \\
\text { coal; proved } \\
\text { reserves of } \\
\text { other fuels }\end{array}$ & Total reserves \\
\hline $\begin{array}{l}\text { Coal } \\
\text { Petroleum and natural-gas liquids } \\
\text { Natural gas. }\end{array}$ & $\begin{array}{l}86 \\
13 \\
22\end{array}$ & $\begin{array}{r}1,442 \\
148 \\
159\end{array}$ \\
\hline
\end{tabular}

These ratios give additional emphasis to the disparity in quantity between reserves of the several mineral fuels as currently estimated.

In the long history of human affairs, coal, petroleum, and natural gas have been used in large quantities only in the last 50 years. However large the reserves of these fuels may seem at present, the quantities are quite meager when compared with the life expectancy and the predictable future needs of the human race. In analyzing the life expectancy of the United States fuel reserves, Ayres and Scarlott (1952, p. 162) conclude that the mineral fuels alone can supply our future needs for a short period of 75 to 250 years. In analyzing the life expectancy of world fuel reserves, Hubbert $(1951,1956)$ sees the present growth of population and use of energy from the mineral fuels as being unprecedented and impossible of continuation beyond a few hundred years. Ultimately, he believes, population growth must level off, and other sources of energy must be made available, if we are to continue the comfortable standard of living now enjoyed through use of the mineral fuels.

The current predictions that the mineral fuels have a life expectancy of only a few hundred years are not intended to be precise, or discouraging in their outlook for the future. They are intended merely to show the approximate order of magnitude of the 
time during which an advanced technology must develop and harness new sources of energy. During the period of such development we have the comforting assurance that our substantial reserves of coal will meet all foreseeable fuel needs.

\section{SELECTED BIBLIOGRAPHY}

Abernathy, G. E., Jewett, J. M., and Schoewe, W. H., 1947, Coal reserves in Kansas: Kansas Geol. Survey Bull. 70, pt. 1.

Allen, J. E., and Baldwin, E. M., 1944, Geology and coal resources of the Coos Bay quadrangle, Oregon: Oregon Dept. Geology and Mineral Industries Bull. 27.

American Institute of Mining and Metallurgical Engineers, 1924, Valuation of coal mining properties in the United States, report of the engineers' advisory valuation committee of the United States Coal Commission: Trans. 70, p. 794-804.

American Society for Testing Materials, 1954, Standard specifications for classification of coals by rank (A.S.T.M. Designation: D388-38) : A.S.T.M. Standards on coal and coke, p. 79-81.

Ashley, G. H., 1926, Topographic and geologic atlas of Pennsylvania 65, Punxsutawney quadrangle: Pennsylvania Geol. Survey, 4th ser.

1940, Topographic and geologic atlas of Pennsylvania 75, Curwensville quadrangle: Pennsylvania Geol. Survey, 4th ser.

1944, Pennsylvania's mineral heritage, pt. 2, Mineral resources: Harrisburg, Pennsylvania Dept. Internal Affairs.

- 1945, Anthracite reserves: Pennsylvania Topog. and Geol. Survey Prog. Rept. 130.

Ashmead, D. C., 1926, Anthracite losses and reserves in Pennsylvania: Pennsylvania Topog. and Geol. Survey Bull. M8.

Averitt, Paul, Berryhill, L. R., and Taylor, D. A., 1953, Coal resources of the United States (A progress report, October 1, 1953): U.S. Geol. Survey Circ. 293 [1954].

Ayres, Eugene, and Scarlott, C. A., 1952, Energy sources-the wealth of the world: New York, McGraw-Hill Book Co.

Barnes, F. F., 1961, Coal fields of the United States-Alaska: U.S. Geol. Survey Map, sheet 2.

Berryhill, H. L., Jr., Brown, D. M., Brown, Andrew, and Taylor, D. A., 1950, Coal resources of Wyoming: U.S. Geol. Survey Circ. 81.

Berryhill, H. L., Ir., Brown, D. M., Burns, R. N., and Combo, J. X., 1951, Coal resources map of Wyoming: U.S. Geol. Survey Coal Inv. Map C-6.

Berryhill, L. R., and Averitt, Paul, 1951, Coking-coal deposits of the Western: United States: U.S. Geol. Survey Circ. 90.

Blaylock, D. W., Dowd, J. J., Abernethy, R. F., and Reynolds, D. A., 1955, Estimate of known recoverable reserves of coking coal in Clearfleld County, Pennsylvania: U.s. Bur. Mines Rept. Inv. 5166.

- 1956, Estimate of known recoverable reserves of coking coal in Clarion County, Pennsylvania: U.S. Bur. Mines Rept. Inv. 5231.

Blondel, F. A. J., and Lasky, S. G., 1956, Mineral reserves and mineral resources: Econ. Geology, จ. 51, no. 7, p. 692.

Bowen, C. F., 1913, Lignite in the Goose Creek district, Cassia County, Idaho: U.S. Geol. Survey Bull. 531-H, p. 252-262. 
Brant, R. A., 1953, Lignite resources of North Dakota: U.S. Geol. Survey Circ. 226.

1954, The Lower Kittanning No. 5 coal bed in Ohio: Ohio Div. Geol. Survey Rept. Inv. 21.

1956, Coal resources of the upper part of the Allegheng formation in Ohio: Ohio Div. Geol. Survey Rept. Inv. 29.

Brant, R. A., and DeLong, R. M., 1960, Coal resources of Ohio: Ohio Div. Geol. Survey Bull. 58.

Brown, Andrew, Berryhill, H. L., Jr., Taylor, D. A., and Trumbull, J. V. A., 1952, Coal resources of Virginia: U.S. Geol. Survey Circ. 171.

Brown, Andrew, Culbertson, W. C., Dunham, R. J., Kepferle, R. C., and May, P. R., 1954, Strippable coal in Custer and Powder River Counties, Montana: U.S. Geol. Survey Bull. 995-E.

Brown, D. M., 1952, Lignite resources of South Dakota: U.S. Geol. Survey Circ. 159.

Brown, Frederick, 1948, Statistical year-book of the World Power Conference, no. 4: London, World Power Conference, Central office.

1950, Statistical year-book of the World Power Conference, no. 5: London, World Power Conference, Central office.

1952, Statistical year-book of the World Power Conference, no. 6: London, World Power Conference, Central office.

1954, Statistical year-book of the World Power Conference, no. 7: London, World Power Conference, Central office.

1956, Statistical year-book of the World Power Conference, no. 8: London, World Power Conference, Central office.

Buch, J. W., Hendricks, T. A., and Toenges, A. L., 1947, Coal, in Mineral position of the United States: Hearings before a subcommittee of the Committee on Public Lands, U.S. Senate, 80th Cong., 1st sess., May 15, 16, and 20, p. 231-235.

Butts, Charles, and Gildersleeve, Benfamin, 1948, Geology and mineral resources of the Paleozolc area in northwest Georgia: Georgia Geol. Survey Bull. 54.

Cady, G. H., 1949, Coal resources of Franklin County, Illinois: Illinois Geol. Survey Circ. 151, p. 65-76.

Cady, G. H., and others, 1952, Minable coal reserves of Illinois: Illinois Geol. Survey Bull. 78.

Campbell, M. R., and Parker, E. W., 1909, Coal fields of the United States: U.S. Geol. Survey Bull. 394, p. 5-26.

Campbell, M. R., 1917, Coal fields of the United States, General introduction: U.S. Geol. Survey Prof. Paper 100-A, table facing p. 24. [Revised and reprinted 1922; reprinted 1929.]

1929, Coal resources of the United States: U.S. Geol. Survey Press Release.

Cashion, W. B., 1961, Geology and fuel resources of the Orderville-Glendale area, Kane County, Utah: U.S. Geol. Survey Coal Inv. Map C-49.

Clark, F. R., 1912, Coal near Wales, Sanpete County, Utah: U.S. Geol. Survey Bull. 541 , p. $478-489$.

1918, Geology of the Lost Creek coal field, Morgan County, Utah: U.S. Geol. Survey Bull. 691-L, p. 311-322.

- 1928, Economic geology of the Castlegate, Wellington, and Sunnyside quadrangles, Carbon County, Utah: U.S. Geol. Survey Bull. 793, p. 100103 and 159-162.

$586968-61-8$ 
Cohee, G. V., Burns, R. N., Brown, Andrew, Brant, R. A., and Wright, Dorothy, 1950, Coal resources of Michigan: U.S. Geol. Survey Circ. 77.

Combo, J. X., Brown, D. M., Pulver, H. F., and Taylor, D. A., 1949, Coal resources of Montana: U.S. Geol. Survey Circ. 53.

Combo, J. X., Holmes, C. N., and Christner, H. R., 1950, Map showing coal resources of Montana: U.S. Geol. Survey Coal Inv. Map C-2.

Corps of Engineers, Dept. of the Army, 1952, The synthetic liquid fuel potential of the United States-a report to the U.S. Bureau of Mines.

Culbertson, W. C., 1954, Three deposits of strippable lignite west of the Yellowstone River, Montana: U.S. Geol. Survey Bull. 995-H.

DeBrosse, T. A., 1957, Coal beds of the Conemaugh formation in Ohio: Ohio Div. Geol. Survey Rept. Inv. No. 34.

DeLong, R. M., 1955, The Pittsburgh No. 8 and Redstone No. 8A coal beds in Ohio: Ohio Div. Geol. Survey Rept. Inv. 26.

- 1957, Coal resources of the lower part of the Allegheny formation in Ohio: Ohio Div. Geol. Survey Rept. Inv. 31.

Denson, N. M., Bachman, G. O., and Zeller, H. D., 1959, Uranium-bearing lignite in northwestern South Dakota and adjacent States: U.S. Geol. Survey Bull. 1055-B.

Denson, N. M., and Gill, J. R., 1956, Uranium-bearing lignite and its relation to volcanic tuffs in eastern Montana and North and South Dakota: U.S. Geol. Survey Prof. Paper 300, p. 413-418.

Deul, Maurice, and Annell, C. S., 1956, The occurrence of minor elements in ash of low-rank coal from Texas, Colorado, North Dakota, and South Dakota: U.S. Geol. Survey Bull. 1036-H.

Dowd, J. J., Provost, J. M., Abernethy, R. F., and Reynolds, D. A., 1955, Estimate of known recoverable reserves of coking coal in Ohio County, West Virginia: U.S. Bur. Mines Rept. Inv. 5171.

- 1956, Estimate of known recoverable reserves of coking coal in Marshall County, West Virginia: U.S. Bur. Mines Rept. Inv. 5207.

Dowd, J. J., Provost, J. M., Travis, R. G., Abernethy, R. F., and Reynolds, D. A., 1955, Estimate of known recoverable reserves of coking coal in Brooke County, West Virginia: U.S. Bur. Mines Rept. Inv. 5160.

Dowd, J. J., Toenges, A. L., Abernethy, R. F., and Reynolds, D. A., 1952, Estimate of known recoverable reserves of coking coal in Jefferson County, Pennsylvania: U.S. Bur. Mines Rept. Inv. 4840.

- 1952, Estimate of known recoverable reserves of coking coal in Raleigh County, West Virginia : U.S. Bur. Mines Rept. Inv. 4893.

— 1952, Estimate of known recoverable reserves of coking coal in Knott County, Kentucky: U.S. Bur. Mines Rept. Inv. 4897.

Dowd, J. J., Turnbull, L. A., Toenges, A. L., Cooper, H. M., Abernethy, R. F., Reynolds, D. A., and Fraser, Thomas, 1950, Estimate of known recoverable reserves of coking coal in Cambria County, Pennsylvania: U.S. Bur. Mines Rept. Inv. 4734.

Dowd, J. J., Turnbull, L. A., Toenges, A. L., Cooper, H. M., Abernethy, R. F., Reynolds, D. A., and Crentz, W. L., 1950, Estimate of known recoverable reserves of coking coal in Indiana County, Pennsylvania: U.S. Bur. Mines Rept. Inv. 4757.

Dowd, J. J., Turnbull, L. A., Toenges, A. L., Abernethy, R. F., and Reynolds, D. A., 1951, Estimate of known recoverable reserves of coking coal in Pike County, Kentucky: U.S. Bur. Mines Rept. Inv. 4792.

1951, Estimate of known recoverable reserves of coking coal in Armstrong County, Pennsylvania: U.S. Bur. Mines Rept. Inv. 4801. 
1951, Estimate of known recoverable reserves of coking coal in Westmoreland County, Pennsylvania : U.S. Bur. Mines Rept. Inv. 4803.

- 1951, Estimate of known recoverable reserves of coking coal in Fayette County, Pennsylvania: U.S. Bur. Mines Rept. Inv. 4807.

- 1951, Estimate of known recoverable reserves of coking coal in Floyd County, Kentucky : U.S. Bur. Mines Rept. Inv. 4813.

Duncan, D. C., 1944, The Mount Pleasant coal field, Sanpete County, Utah: U.S. Geol. Survey Coal Inv. Map.

- 1953, Geology and coal deposits in part of the Coos Bay coal field, Oregon: U.S. Geol. Survey Bull. 982-B.

1958, Oil shale deposits in the United States: Independent Petroleum Assoc. America Bull., v. 29, no. 4, p. 22.

Eavenson, H. N., 1946, Wasting a valuable national resource (bituminous coal) : Am. Inst. Mining Metall. Engineers Trans., v. 168, p. 11-14.

Elder, J. L., Fies, M. H., Graham, H. G., Capp, J. P., and Sarapuu, Erich, 1957, Field-scale experiments in underground gasification of coal at Gorgas, Alabama : U.S. Bur. Mines Rept. Inv. 5367.

Fieldner, A. C., Rice, W. E., and Moran, H. E., 1942, Typical analyses of coals of the United States: U.S. Bur. Mines Tech. Paper 446.

Fieldner, A. C., 1950, Coal for coke production: U.S. Bur. Mines Inf. Circ. 7559.

Fisher, D. J., 1936, The Book Cliffs coal field in Emery and Grand Counties, Utah: U.S. Geol. Survey Bull. 852, p. 56.

Flint, N. K., 1951, Geology of Perry County: Ohio Geol. Survey, 4th ser., Bull. 48.

Francis, Wilfrid, 1954, Coal, its formation and composition: London, Edward Arnold, Ltd.

Gale, H. S., 1910, Coal fields of northwestern Colorado and northeastern Utah : U.S. Geol. Survey Bull. 415, p. 233-239.

Granchi, J. A., 1958, Coal resources of the Pottsville formation: Ohlo Div. Geol. Survey Rept. Inv. No. 36.

Gregory, H. E., and Moore, R. C., 1931, The Kaiparowits region: U.S. Geol. Survey Prof. Paper 164, p. 148-153; pl. 30.

Gregory, H. E., 1938, The San Juan country : U.S. Geol. Survey Prof. Paper 188, p. 110.

Haley, B. R., 1960, Coal resources of Arkansas : U.S. Geol. Survey Bull. 1072-P, p. 795-831.

Hance, J. H., 1913, The Coaldale coal field, Esmeralda County, Nevada: U.S. Geol. Survey Bull. 531-K, p. 313-322.

Headlee, A. J. W., and Hunter, R. G., 1951, Germanium in coals of West VIrginia : West Virginia Geol. Econ. Survey Rept. Inv. 8.

Headlee, A. J. W., and Nolting, J. P., 1940, Characteristics of minable coals of West Virginia : West Virginia Geol. Survey, v. 13.

Hershey, R. E., Williams, Lloyd, Crentz, W. L., and Miller, J. W., 1956, Est1mate of known recoverable reserves and the preparation characteristics of coking coal in Van Buren County, Tennessee: U.S. Bur. Mines Rept. Inv. 5208.

- 1956, Estimate of known recoverable reserves and the preparation characteristics of coking coal in Hamilton County, Tennessee: U.S. Bur. Mines Rept. Inv. 5263.

Hershey, R. E., Williams, Lloyd, Crentz, W. L., Miller, J. W., and Reynolds, D. A., 1956, Estimate of known recoverable reserves and the preparation and carbonizing properties of coking coal in Claiborne County, Tennessee: U.S. Bur. Mines Rept. Inv. 5229. 
Hershey, R. E., Williams, Lloyd, and Gandrud, B. W., 1955, Estimate of known recoverable reserves of coking coal in Grundy County, Tennessee : U.S. Bur. Mines Rept. Inv. 5148.

Hickok, W. O., IV, and Moyer, F. T., 1940, Geology and mineral resources of Fayette County, Pennsylvania: Pennsylvania Geol. Survey, 4th ser., Bull. C-26.

Hinds, Henry, 1913, The coal deposits of Missouri : Missouri Bur. Geology and Mines, $2 d$ ser., v. 11.

Hubbert, M. K., 1951, Energy from fossil fuels: Smithsonian Institution, Ann. Rept., 1950, p. 255-271.

- 1956, Nuclear energy and the fossil fuels: Drilling and production practice; Am. Petroleum Inst., p. 7-25.

Huddle, J. W., and others, 1961, Coal reserves of eastern Kentucky: U.S. Geol. Survey Bull. 1120. (In press.)

Hunt, C. B., and others, 1953, Geology and geography of the Henry Mountains region, Utah: U.S. Geol. Survey Prof. Paper 228, p. 216-217; pl. 22.

International Geological Congress, 12th, 1913, The coal resources of the world (inquiry made on initiative of executive committee): Toronto, Canada, Morang \& Co.

Jennings, C. W., 1957, Coal, in Mineral commodities of California : California Div. Mines Bull. 176, p. 153-164.

Johnson, V. H., 1946, Coal deposits on Sand and Lookout Mountains, Dade and Walker Counties, Georgia: U.S. Geol. Survey Coal Inv. Map.

Joint Committee on Atomic Energy, 1956, Peaceful uses of atomic energy; background material for the report of the Panel on the Impact of the Peaceful Uses of Atomic Energy to the Joint Committee on Atomic Energy : Joint Committee print, 84th Cong., 2d sess., v. 2.

Karp, S. E., 1949, California coal : Compass, v. 26, p. 341-344.

Kehn, T. M., 1957, Selected annotated bibliography of the geology of uraniumbearing coal and carbonaceous shale in the United States: U.S. Geol. Survey Bull. 1059-A.

Kepferle, R. C., 1954, Selected deposits of strippable coal in central Rosebud County, Montana: U.S. Geol. Survey Bull. 995-I.

Kepferle, R. C., and Culbertson, W. C., 1955, Strippable lignite deposits, Slope and Bowman Counties, North Dakota: U.S. Geol. Survey Bull. 1015-E.

Kiersch, G. A., 1955, Mineral resources, Navajo-Hopi Indian reservations, Arizona-Utah, v. 1, Metalliferous minerals and mineral fuels: Tucson, Arizona Univ., p. 51.

Kinney, D. M., 1955, Geology of the Uinta River-Brush Creek area, Duchesne and Uintah Counties, Utah: U.S. Geol. Survey Bull. 1007, p. 143-149.

Koenig, R. P., 1950, Economics and technique of strip coal mining, in Coal and Metal Mining, Colorado School Mines Quart., v. 45, no. 2 B, p. 27-39.

Krauskopf, K. B., 1955, Sedimentary deposits of rare metals: Econ. Geology, 50th anniversary volume, pt. 1, p. 411-463.

Landis, E. R., 1959, Coal resources of Colorado: U.S. Geol. Survey Bull. 1072-C.

Lesley, J. P., D'Invilliers, E. V., and Smith, A. D. W., 1895, Final report1892-95: Pennsylvania Geol. Survey, $2 d$ ser., v. 3, pt. 1, p. 2147-2152.

Lowe, R. W., Crentz, W. L., and Miller, J. W., 1956, Estimate of known recoverable reserves and the preparation characteristics of coking coal in Fentress County, Tennessee: U.S. Bur. Mines Rept. Inv. 5235.

Lupton, C. T., 1912, The Blacktail (Tabby) Mountain coal field, Wasatch County, Utah: U.S. Geol. Survey Bull. 471, p. 628. 
1916, Geology and coal resources of Castle Valley in Carbon, Emery, and Sevier Counties, Utah: U.S. Geol. Survey Bull. 628, p. 86.

Luther, E. T., 1959, The coal reserves of Tennessee: Tennessee Div. Geology Bull. 63.

McCallie, S. W., 1904, A preliminary report on the coal deposits of Georgia: Georgia Geol. Survey Bull. 12.

MacKay, B. R., 1947, Coal reserves of Canada : Royal Comm. Coal Rept., 1946.

Mapel, W. J., and Hail, W. J., Jr., 1959, Tertiary geology of the Goose Creek district, Cassia County, Idaho; Box Elder County, Utah ; and Elko County, Nevada: U.S. Geol. Survey Bull. 1055-H.

Mason, Brian, 1958, Principles of geochemistry : New York, John Wiley \& Sons, Inc.; London, Chapman \& Hall, Ltd.

Mason, R. S., and Erwin, M. I., 1955, Coal resources of Oregon: U.S. Geol. Survey Circ. 362.

May, P. R., 1954, Strippable lignite deposits in the Wibaux area, Montana and North Dakota: U.S. Geol. Survey Bull. 995-G.

Miller, R. L., 1958, A new look at ultimate natural gas reserves: World Oil, v. 147 , no. 5 , p. 222.

Oil and Gas Jour., 1958, What is U.S. productive capacity?: v. 56, no. 20 (May 19), p. 114.

- 1959a, Imports rose to all-time high in '58: v. 57, no. 4 (Jan. 26), p. 150.

1959b, Reserves bounce back, hit new peak: v. 57, no. 13 (Mar. 23), p. $49-51$.

Page, L. R., Stocking, H. E., and Smith, H. B., compilers, 1956, Contributions to the geology of uranium and thorium by the United States Geological Survey and Atomic Energy Commission for the United Nations International Conference on Peaceful Uses of Atomic Energy, Geneva, Switzerland, 1955: U.S. Geol. Survey Prof. Paper 300.

Pepperberg, R. V., 1910, Coal in Nebraska: Nebraska Geol. Survey, v. 3, pt. 10, p. 275-307.

Perkins, J. M., and Lonsdale, J. T., 1955, Mineral resources of the Texas coastal plain, [a] report for Bureau of Reclamation, Department of Interior: Texas Univ., Bur. Econ. Geology, p. 28-36.

President's Materials Policy Commission, 1952, Resources for freedom, the outlook for energy sources: Washington, U.S. Govt. Printing Offlce, v. 3, p. 24-31.

Price, P. H., Tucker, R. C., and Haught, O. L., 1938, Geology and natural resources of West Virginia: West Virginia Geol. Survey, v. 10.

Provost, J. M., Dowd, J. J., Abernethy, R. F., and Reynolds, D. A., 1956, Estimate of known recoverable reserves of coking coal in Marion County, West Virginia : U.S. Bur. Mines Rept. Inv. 5267.

Read, C. B., Duffner, R. T., Wood, G. H., and Zapp, A. D., 1950, Coal resources of New Mexico: U.S. Geol. Survey Circ. 89.

Reese, J. F., and Sisler, J. D., 1928, Bituminous coal fields of Pennsyivanla : Pennsylvania Topog. and Geol. Survey Bull. M-6, Coal resources, p. 1-9.

Reinemund, J. A., 1949, Deep River coal field, Chatham, Lee, and Moore Counties, North Carolina: U.S. Geol. Survey Coal Inv. Map.

—_ 1955, Geology of the Deep River coal field, North Carolina: U.S. Geol. Survey Prof. Paper 246, p. 113-115.

Rice, G. S., 1921, Analyses of Iowa coal: U.S. Bur. Mines Tech. Paper 269, p. 9.

Richardson, G. B., 1909, The Harmony, Colob, and Kanab coal fields, southern Utah: U.S. Geol. Survey Bull. 341, p. 384-388. 
Roberts, A. E., 1958, Geology and coal resources of the Toledo-Castle Rock district, Cowlitz and Lewis Counties, Washington: U.S. Geol. Survey Bull. 1062.

Rothrock, H. E., 1950, A summary and critique of the estimates of Pennsylvania anthracite reserves, in Symposium on mineral resources in Pennsylvania : Pennsylvania Acad. Sci. Proc., v. 24, p. 192-197.

Schleicher, J. A., and Hambleton, W. W., 1954, Preliminary spectrographic investigation of germanium in Kansas coal: Geol. Survey Kansas Bull. 109, pt. 8, p. 113-124.

Schoewe, W. H., 1951a, Current coal research-coal geology in Kansas: Econ. Geology, v. 46, no. 8, p. 852-856.

- 1951b, Coal resources of the Permian system in Kansas: Kansas Geol. Survey Bull. 90, pt. 3.

1952, Coal resources of the Cretaceous system (Dakota formation) in central Kansas: Kansas Geol. Survey Bull. 96, pt. 2.

Selvig, W. A., and Gibson, F. H., 1956, Analyses of ash from United States coals: U.S. Bur. Mines Bull. 567.

Shaffner, M. N., 1946, Topographic and geologic atlas of Pennsylvania, no. 55, Smicksburg quadrangle: Pennsylvania Geol. Survey, 4th ser.

Smith, A. D. W., 1893, Report of Pennsylvania Coal Waste Commission: Philadelphia, Allen, Lane \& Scott's Printing House.

Smith, G. O., and others, 1913, The classification of public lands: U.S. Geol. Survey Bull. 537, p. 88.

Smith, W. H., 1957, Strippable coal reserves of Illinois, pt. 1-Gallatin, Hardin, Johnson, Pope, Saline, and Williamson Counties: Illinois Geol. Survey Circ. 228.

- 1958, Strippable coal reserves of Illinois, pt. 2-Jackson, Monroe, Perry, Randolph, and St. Clair Counties: Illinois Geol. Survey Circ. 260.

Smith, W. H., Brant, R. A., and Amos, Fred, 1952, The Meigs Creek No. 9 coal bed in Ohio, pt. 1, Geology and reserves: Ohio Div. Geol. Survey Rept. Inv. 17, p. 1-36 [1953].

Snavely, P. D., Jr., Roberts, A. E., Hoover, Linn, Jr., and Pease, M. H., Jr., 1951, Geology of the eastern part of the Centralia-Chehalis coal district, Lewis and Thurston Counties, Washington: U.S. Geol. Survey Coal Inv. Map C-8. [Superseded by Bull. 1053.]

Snavely, P. D., Jr., Brown, R. D., Jr., Roberts, A. E., and Rau, W. W., 1958, Geology and coal resources of the Centralia-Chehalis district, Washington: U.S. Geol. Survey Bull. 1053.

Soper, E. K., and Osbon, C. C., 1922, The occurrence and uses of peat in the United States: U.S. Geol. Survey Bull. 728.

Spencer, F. D., 1953, Coal resources of Indiana: U.S. Geol. Survey Circ. 266.

Spieker, E. M., and Baker, A. A., 1928, Geology and coal resources of the Salina Canyon district, Sevier County, Otah: U.S. Geol. Survey Bull. 796-C, p. 151-152.

Spieker, E. M., 1931, The Wasatch Plateau coal field, Utah: U.S. Geol. Survey Bull. 819, p. 201-206.

Stadnichenko, Taisia, and others, 1953, Concentration of germanium in the ash of American coals-a progress report: U.S. Geol. Survey Circ. 272.

Sullivan, J. W., 1942, The geology of the Sand-Lookout Mountain area, northwest Georgia: Georgia Div. Geology Inf. Circ. 15.

Tavenner, W. H., Dowd, J. J., Abernethy, R. F., and Reynolds, D. A., 1956, Estimate of known recoverable reserves of coking coal in Logan County, West Virginia: U.S. Bur. Mines Rept. Inv. 5259. 
Toenges, A. L., and others, 1946, Exploration, composition, and washing, burning, and gas-producer tests of a coal occurring near Coaldale, Esmeralda County, Nevada: U.S. Bur. Mines Tech. Paper 687.

1948, Minable reserves, petrography, chemical characteristics, and washability tests of coal occurring in the Coos Bay field, Coos County, Oregon: U.S. Bur. Mines Tech. Paper 707.

Toenges, A. L., Turnbull, L. A., Williams, Lloyd, Smith, H. L., O'Donnell, H. J., Cooper, H. M., Abernethy, R. F., and Waage, Karl, 1949, Investigations of the lower coal beds in Georges Creek and north part of Upper Potomac basins, Allegany and Garrett Counties, Maryland: U.S. Bur. Mines Tech. Paper 725.

'Toenges, A. L., Williams, Lloyd, Turnbull, L. A., Parks, B. C., O'Donnell, H. J., Abernethy, R. F., Ode, W. H., and Waagé, Karl, 1952, Castleman Basin, Garrett County, Maryland: U.S. Bur. Mines Bull. 507.

Travis, R. G., Dowd, J. J., Abernethy, R. F., and Reynolds, D. A., 1956, Estimate of known recoverable reserves of coking coal in Monongalia County, West Virginia: U.S. Bur. Mines Rept. Inv. 5233.

Trumbull, James, 1957, Coal resources of Oklahoma: U.S. Geol. Survey Bull. 1042-J.

- 1960, Coal fields of the United States, exclusive of Alaska: U.S. Geol. Survey Map, sheet 1.

United Nations, 1957, New sources of energy and economic development: New York, United Nations Dept. Econ. Social Affairs.

U.S. Bureau of Mines, 1959a, Bituminous coal and lignite in 1958: Mineral Market Summary 2974, Sept. 9, 1959.

- 1959b, Minerals Yearbook, 1957, v. 2, Fuels.

1959c, Peat in 1958: Mineral Market Rept. M.M.S. 2902.

Veatch, A. C., 1911, Coal deposits near Pinedale, Navajo County, Arizona: U.S. Geol. Survey Bull. 431-B, p. 239-242.

Wallace, J. J., Dowd, J. J., Bowsher, J. A., Abernethy, R. F., and Reynolds, D. A., 1953, Estimate of known recoverable reserves of coking coal in Somerset County, Pennsylvania: U.S. Bur. Mines Rept. Inv. 4998.

Wallace, J. J., Dowd, J. J., Provost, J. M., Abernethy, R. F., and Reynolds, D. A., 1953, Estimate of known recoverable reserves of coking coal in Allegheny County, Pennsylvania: U.S. Bur. Mines Rept. Inv. 5003.

- 1955, Estimate of known recoverable reserves of coking coal in Washington County, Pennsylvania: U.S. Bur. Mines Rept. Inv. 5109.

- 1955, Estimate of known recoverable reserves of coking coal in Green County, Pennsylvania: U.S. Bur. Mines Rept. Inv. 5143.

Wallace, J. J.., Dowd, J. J., Tavenner, W. H., Abernethy, R. F., and Reynolds, D. A., 1953, Estimate of known recoverable reserves of coking coal in Wyoming County, West Virginia : U.S. Bur. Mines Rept. Inv. 4966.

- 1954, Estimate of known recoverable reserves of coking coal in Mingo County, West Virginia: U.S. Bur. Mines Rept. Inv. 5068.

Wallace, J. J., Dowd, J. J., Tavenner, W. H., Provost, J. M., Abernethy, R. F., and Reynolds, D. A., 1952, Estimate of known recoverable reserves of coking coal in McDowell County, West Virginia: U.S. Bur. Mines Rept. Inv. 4924.

- 1954, Estimate of known recoverable reserves of coking coal in Mercer County, West Virginia: U.S. Bur. Mines Rept. Inv. 5077.

Wallace, J. J., Dowd, J. J., Travis, R. G., Abernethy, R. F., and Reynolds, D. A., 1953, Estimate of known recoverable reserves of coking coal in Letcher County, Kentucky: U.S. Bur. Mines Rept. Inv. 5016. 
1954, Estimate of known recoverable reserves of coking coal in Harlan County, Kentucky: U.S. Bur. Mines Rept. Inv. 5037.

1954, Estimate of known recoverable reserves of coking coal in Perry County, Kentucky: U.S. Bur. Mines Rept. Inv. 5083.

Wallace, J. J., Dowd, J. J., Williams, Lloyd, Abernethy, R. F., and Reynolds, D. A., 1953, Estimate of known recoverable reserves of coking coal in Allegany County, Maryland: U.S. Bur. Mines Rept. Inv. 4970.

Warren, W. C., Norbisrath, H., Grivetti, R. M., and Brown, S. P., 1945, Coal fields of King County, Washington: U.S. Geol. Survey Coal Inv. Map.

Weeks, L. G., 1958, Fuels reserves of the future: Am. Assoc. Petroleum Geologists Bull., v. 42 , no. 2, p. 431-438.

1959, Energy in 2059: Oil and Gas Jour., v. 57, no. 46 (Nov. 9), p. 109.

Wegemann, C. H., 1915, The Coalville coal field, Utah: U.S. Geol. Survey Bull. 581, p. 161-184.

Williams, Lloyd, Abernethy, R. F., Gandrud, B. W., Reynolds, D. A., and Wolfson, D. E., 1955, Estimate of known recoverable reserves and the preparation and carbonizing properties of coking coal in Overton County, Tennessee: U.S. Bur. Mines Rept. Inv. 5131.

Williams, Lloyd, Gibbs, H. K., Crentz, W. L., and Miller, J. W., 1956, Estimate of known recoverable reserves and the preparation characteristics of coking coal in Scott County, Tennessee: U.S. Bur. Mines Rept. Inv. 5232. - 1956, Estimate of known recoverable reserves and the preparation and carbonizing properties of coking coal in Campbell County, Tennessee: U.S. Bur. Mines Rept. Inv. 5258.

Williams, Lloyd, and Hershey, R. E., 1956, Estimate of known recoverable reserves of coking coal in Bledsoe County, Tennessee: U.S. Bur. Mines Rept. Inv. 5234.

Williams, Lloyd, Hershey, R. E., Abernethy, R. F., Gandrud, B. W., and Reynolds, D. A., 1955, Estimate of known recoverable reserves and the preparation and carbonizing properties of coking coal in Sequatchie County, Tennessee: U.S. Bur. Mines Rept. Inv. 5136.

Williams, Lloyd, Hershey, R. E., and Gandrud, B. W., 1955, Estlmate of known recoverable reserves and the preparation and carbonizing properties of coking coal in Marion County, Tennessee: U.S. Bur. Mines Rept. Inv. 5159.

Williams, Lloyd, James, Curtis, Crentz, W. L., and Miller, J. W., 1956, Estimate of known recoverable reserves and the preparation characteristics of coking coal in Morgan County, Tennessee: U.S. Bur. Mines Rept. Inv. 5266.

Williams, Lloyd, James, C. W., Gandrud, B. W., and Reynolds, D. A., 1956, Estimate of known recoverable reserves and the preparation and carbonizing properties of coking coal in Anderson County, Tennessee: U.S. Bur. Mines Rept. Inv. 5185.

Williams, Lloyd, Lowe, Robert, Turnbull, L. A., Carman, E. P., Crentz, W. L., Reynolds, D. A., and Abernethy, R. F., 1954, Estimate of known recoverable reserves and the preparation and carbonizing properties of coking coal in Putnam County, Tennessee: U.S. Bur. Mines Rept. Inv. 5029.

Wrather, W. E., Boyd, James, Smith, N. L., and Ayers, Eugene, 1950, Energy resources of the United States: London, Fourth World Power Conference.

Young, W. H., and Anderson, R. L., 1957, Thickness of bituminous-coal and lignite seams at all mines, and thickness of overburden at strip mines in the United States in 1955: U.S. Bur. Mines Inf. Circ. 7812. 


\section{INDEX}

Page

Acknowledgments....................................... American Soctety for Testing Materiais....... Appalachian region, recovery of bituminous coal.

A real extent of coalbeds, estimation of ......... Arkansas Valley coal fleld.

Arsenic, as minor element in coal. use in manufacture of concrete and cinder blocks.

Barium, as minor element in coal

Bibllography

Blacktall (Tabby) Mountain field, Utah...

Boron, as minor element in coal............... 41, 42

Broad Pass coal fleld, Alaska.

Cahaba coal field, Alabama

Campbell, M. R., cited

Castleman basin, Maryland

Char........................................ 32

Chemicals, derived from coal..................- 39

Classincation, reserves....................... 55

Coal-forming process........................ 15

Coal-reserve estimates, preparing and reporting.

Coking-coal reserves 12-26

32-34

Coosa coal fleld, Alabama.................... 44, 45

Cumnock bed, North Carolina..................

Curwensville quadrangle, Pennsylvania.......

Deep River feld, North Carolina

68-69

Distributlon of reserves, in selected categories. 26-32

Dye, from lignite.

93-94

Energy, annual production relation of coal to other forms of......... 93-103

Extent, areal, of coalbeds.

Fixed carbon, in classiffcation of coal......... 14

Fuel reserves, life expectancy of U.S. supply. 102-106 problems of comparing estimates of ....... 96-97

Gas, natural reserves. 100-101

Georges Oreek basin, Maryland. 61,62

Germanium, as minor element in coal........ 41-42

Grade, coal 15-17

Great Plalns regions, northern, ownership of coal lands in.

Gulf coalbed, North Carolina.

Henry Mountains field, Utah.

Indicated reserves, defined.

Inferred reserves, defined.
Page

Information, sources, in preparing reserve

15

Jarvis Creek coal fleld, Alaska................ 46

Jawbone coalbed, Virginia..................... 81

Kaiparowits Plateau, Utah................... 78

Kenal coal feld, Alaska........................ 46

Kennedy coalbed, Virginla.................... 81

Lead, as minor element in coal.................. 41

Leonardite.................................... 40

Lignite........................... 45, 50, 59, 69, 76, 78

Lower Hartshorne bed, Oklahoma............ 72

Lower Kittanning bed, Ohlo, germanium in.. 42

Lower Youghlogheny basin, Maryland........ 61

Manufacturing industries, as consumer of coal_ $\quad 39$

Maps, geologic, use in estimates of reserves... 5

Matanuska coal fleld, Alaska................. 46, 48

Measured reserves, definition.................. 21-22

Methods of preparing and reporting coal-re-

serve estimates..................... 12-26

Mineral Leasing Act of $1920 \ldots . . . . . . . . . . . . . .43$

Mining, strip.......................... 25-26, 34-36

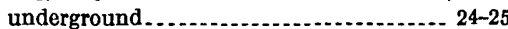

Minor elements in coal. ..................... 40-44

Mississippl Valley region, ownership of coal

lands in......................... 43

Modulus of irregularity ................... 19, 20,74

Molybdenum, as minor element in coal........ 41

Montan wax....................................... 40

Nenana coal field, Alaska.................... 46, 48

Ornamental objects, from anthracite........... 40

Overburden, distribution of reserves according

to thickness of ..................... 29-31

thlckness in calculation of reserves........ 20-21

Ownership, of coal lands...................... 42-44

Oxides, content in coal ash.................... 40

Peat, reserves.............................. 89-91

Petroleum, reserves........................... 98-100

Phosphorous, content in lignite and carbona-

ceous shale.................... 41

Pittsburgh bed.............................. 61, 70

recovery from .............................. 24-25

Plateau coal field, Alabama................... 44

Powder River Basin, Montana............... 66

Wyoming............................... 83

Production of coal in the United States...... 36-38

Proved reserves, term deflned................. 58

22 Punxsutawney quadrangle, Pennsylvania.... 73-74 


\begin{tabular}{|c|c|}
\hline Page & Page \\
\hline n. & Reserves-Continued \\
\hline Rank, distribution of rese & Virginia_.......................... 29, 81-82 \\
\hline Rank of coal............ & Washington. \\
\hline Raton Mesa fleld, New I & West Virginia........... \\
\hline Raven coalbed, Virginia. & world \\
\hline Recoverability, in strip mi & Wyoming................ \\
\hline in underground $\mathrm{min}$ & Resins from bituminous coal.... \\
\hline eserves, additional not & 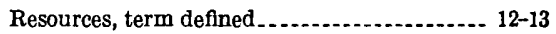 \\
\hline Alabama .............. & Rocky Mountain region, ownership of coal \\
\hline Alaska............... & 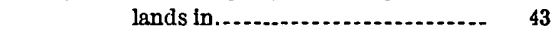 \\
\hline Árkansas......... & \\
\hline classification..... & Shale, carbonaceous, uranium content of. \\
\hline Colorado.......... & Smicksburg quadrangle, Pennsylvania..... \\
\hline Georgia............... & Splash Dam coalbed, Virginia. \\
\hline Illinois............ & Steel industry, as consumer of coal. \\
\hline Indiana............. & Stripping-coal reserves..... $34-36$ \\
\hline indicated, defined.. & Strip mining, Pennsylvania anthracite field... \\
\hline Inferred, defined... & Wyodak, Wyo \\
\hline Iowa...... $57-58$ & Strontium, as minor element in coal. \\
\hline Kansas................................ 23, 58-59 & 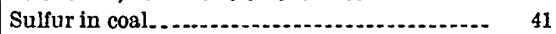 \\
\hline Kentucky............ & Sulfur, content in classification of coal ... 15-17, 40-41 \\
\hline Maryland............... & \\
\hline measured or proved.......... & Thickness of coal, categories of, in calculating \\
\hline Michigan & reserves......................... 18-21 \\
\hline Missouri.................. & distribution of reserves, according to..... 31 \\
\hline Montana & \\
\hline New Mexico & U.S. Army Corps of Engineers, estimate of \\
\hline North Carolina................... 21, $298-69$ & coal reserves.............. 88-89 \\
\hline North Dakota........ & U.S. Coal Commission, committee report.... 88 \\
\hline Ohio.............................. & Upper Hartshorne bed, Oklahoma.............. \\
\hline Oklahoma. $25,71-72$ & Upper Potomac basin, Maryland.......... 61, 62 \\
\hline Oregon. & Upper Youghiogheny basin, Maryland....... 61 \\
\hline 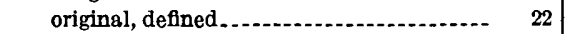 & Uranium, as minor element in coal.......... 41 \\
\hline 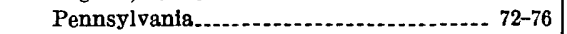 & Uses of coal..... $39-40$ \\
\hline petroleum & Utilities, growth \\
\hline overable, defined. $22-23$ & \\
\hline remaining, defined. 22 & Value, monetary, of coal produced............. \\
\hline $\begin{array}{l}\text { South Dakota. } \\
\text { stripping-coal_............. } 36-77\end{array}$ & 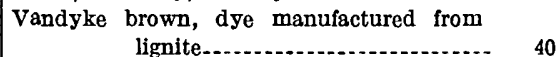 \\
\hline $\begin{array}{l}\text { Tennessee. } \\
\text { term defined........... } 12-13\end{array}$ & Vernal field, Utah.......... 79,80 \\
\hline Texas. ............................ & Warrior coal field..... \\
\hline total & Weight, of coal. \\
\hline Utab. & Wyodak, Wyo., thick coal at... \\
\hline
\end{tabular}

